Lilian Rose Marques de Sá

SÍNDROME DE EMAGRECIMENTO PROGRESSIVO DOS CALITRIQUÍDEOS PROCESSO DE MÁ ABSORÇÃO SEMELHANTE À DOENÇA CELÍACA HUMANA - CARACTERIZAÇÃo CLÍNICA, LABORATORIAL E ANATOMOPATOLÓGICA

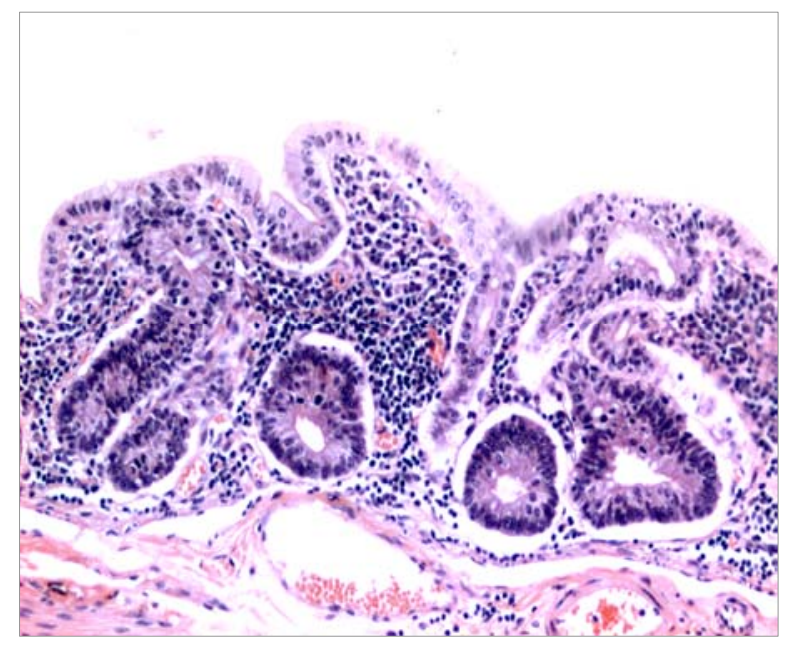

São Paulo

2004 


\section{SÍNDROME DE EMAGRECIMENTO PROGRESSIVO DOS CALITRIQUídEOS - PROCESSO DE MÁ ABSORÇÃO SEMELHANTE À DOENÇA CELÍACA HUMANA - CARACTERIZAÇÃO CLÍNICA, LABORATORIAL E ANATOMOPATOLÓGICA}

Tese apresentada ao Programa de Pós-graduação em Patologia Experimental e Comparada da Faculdade de Medicina Veterinária e Zootecnia da Universidade de São Paulo para obtenção do título de doutor em ciências.

Departamento:

Patologia

Área de concentração:

Patologia Experimental e Comparada

Orientadora:

Profa. Dra. Maria Irma Seixas Duarte

São Paulo 
Autorizo a reprodução parcial ou total desta obra, para fins acadêmicos, desde que citada a fonte.

\section{DADOS INTERNACIONAIS DE CATALOGAÇÃO-NA-PUBLICAÇÃO}

(Biblioteca da Faculdade de Medicina Veterinária e Zootecnia da Universidade de São Paulo)

\section{T.1392 SÁ, Lilian Rose Marques de}

FMVZ Síndrome de emagrecimento progressivo dos calitriquídeos - processo de má absorção semelhante à doença celíaca humana - caracterização clínica, laboratorial e anatomopatológica / Lilian Rose Marques de Sá. - São Paulo : L. R. M. Sá, 2004.

$186 \mathrm{f}$ : : il.

Tese (doutorado) - Universidade de São Paulo. Faculdade de Medicina Veterinária e Zootecnia. Departamento de Patologia Experimental e Comparada, 2004.

Programa de Pós-graduação: Patologia Experimental e Comparada. Área de concentração: Patologia Experimental e Comparada.

Orientadora: Profa. Dra. Maria Irmã Seixas Duarte.

1. Callithrichidae. 2. Sindrome má-absorção animal. 3. Intestino delgado. 4. Primatas. 5. Patologia. 


\section{$P A R E C E R$}

Interessado: Lilian Rose Marques de Sá

Assunto: Protocolo de experimentação adotado em experimento animal.

A Comissão de Bioética da Faculdade de Medicina Veterinária e Zootecnia da Universidade de São Paulo, após analisar o projeto sob o número 431/2004, intitulado: "Síndrome de emagrecimento progressivo em calitriquídeos: caracterização clínico-laboratorial e anatomopatológica", no qual foram utilizados 57 saguis, sob responsabilidade da $\operatorname{Prof}^{\mathrm{a}} \operatorname{Dr}^{\mathrm{a}}$ Maria Irma Seixas Duarte, constatou que o mesmo foi realizado de acordo com os princípios de bioética, adotados por esta Comissão.

São Paulo, 19 de maio de 2004

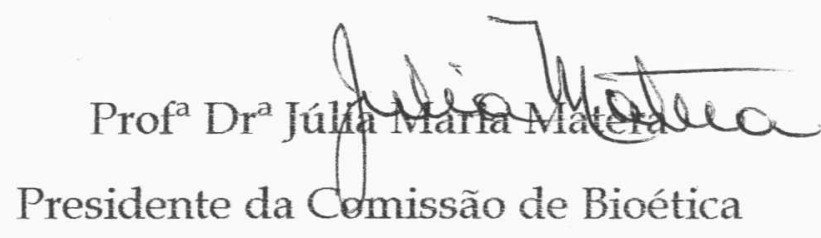

FMVZ/USP 


\section{FOLHA DE AVALIAÇÃO}

Nome: SÁ, Lilian Rose Marques de

Título: Síndrome de emagrecimento progressivo dos calitriquídeos - processo de má absorção semelhante à doença celíaca humana - caracterização clínica, laboratorial e anatomopatológica

Tese apresentada ao Programa de Pós-graduação em Patologia Experimental e Comparada da Faculdade de Medicina Veterinária e Zootecnia da Universidade de São Paulo para obtenção do título de doutor em ciências.

Data:

Banca Examinadora

Prof. Dr.

Instituição:

Assinatura: Julgamento:

Prof. Dr. Instituição:

Assinatura Julgamento:

Prof. Dr. Instituição:

Assinatura: Julgamento:

Prof. Dr. Instituição:

Assinatura: Julgamento:

Prof. Dr. Instituição:

Assinatura: Julgamento: 
Aos meus pais

Aos meus amigos 


\section{AGRADECIMENTOS}

À professora Dra. Maria Irma Seixas Duarte pela confiança e respeito depositados durante todo esse percurso, e por ter sido a minha PROFESSORA.

A Lívia Botar, coordenadora do Criadouro Mucky, por ter possibilitado e acreditado nesse projeto, e por ter me mostrado que cada sagüi é UM sagüi.

Aos funcionários do criadouro Mucky pela paciência e disponibilidade de desempenhar tarefas extras.

Ao professor Dr. Aulus C. Carciofi pela paciência e consideração demonstrada durante a execução desse trabalho.

Ao professor Dr. Heitor Franco de Andrade Junior por ter sido amigo nos momentos em que eu precisei.

Ao professor Dr. José Fernando Benesi pelo estímulo e consideração durante toda a minha formação.

Ao Prof. Dr. José Luiz Guerra pelo constante estímulo, carinho e amizade durante todo meu caminho na patologia animal.

À professora Dra. Eliana Reiko Matushima pel o incentivo e atenção dispensados durante a execução desse projeto.

Á professora Dra. Maria Lúcia Zaidan Dagli, que sempre foi um exemplo de capacidade e generosidade.

Ao professor Dr. Idércio Luiz Sinhorini pelo carinho e apoio sempre presente durante a minha formação.

Ao Professor Dr. Fernando Ferreira pela atenção, auxílio e transparência na solução de questões.

À Regina M. S. Mirandola, minha amiga, que sempre me incentivou e me ensinou.

À Dra. Eliana Scarcelli Pinheiro que sempre foi um exemplo de seriedade e tranparência em apresentar soluções.

Aos colegas do Laboratório da Disciplina de Patologia de Moléstias Transmissíveis da FMUSP: Carla, Cleusinha, Elaine, Mônica, Wellington e Rosana por todos os momentos compartilhados e toda a competência e ajuda em resolver os obstáculos que surgiram.

Ao professor Dr. José Luiz Catão-Dias pelo incentivo inicial e por ter acreditado que eu era capaz.

Aos amigos de tantos momentos, os técnicos Raimundo Nonato Maciel e Edson Luiz de Souza, do Serviço de Anatomia Patológica do VPT, pelo apoio. 
À Sílvia, secretaria do serviço de pós do VPT, pela amizade, apoio e incentivo nos momentos difíceis.

Aos colegas Luciana (UNESP-Jaboticabal), José Luiz Avanzo, Sílvio Luiz pelo apoio e ajuda nos momentos difíceis.

Aos amigos do VPT, VPS e VCM pela solidariedade, cumplicidade e carinho sempre presentes que tornaram os momentos especiais.

Aos meus amigos que jamais faltaram Mariana, Tomie, Anne, Roseli, Karen, Priscyla, Emerson, Ana Paula, Kátia, Marta e Teresa.

Às minhas sobrinhas, Marina e Fernanda, por aceitarem os momentos de ausência.

À Fundação de Amparo à Pesquisa do Estado de São Paulo pelo suporte financeiro, que permitiu a execução deste estudo.

A todos que acreditaram na importância e confiaram na execução deste projeto. 
"Os sonhos não são desafios, são caminho, são destino, liberdade e paixão" Albert Camus 


\section{RESUMO}

SÁ, L. R. M. Síndrome de emagrecimento progressivo dos calitriquídeos - processo de má absorção semelhante à doença celíaca humana - caracterização clínica, laboratorial e anatomopatológica. [Wasting marmoset syndrome is a malabsorption process similar to celiac disease: clinical and pathological characterization]. 2004. 195 f. Tese (Doutorado em Ciências) - Faculdade de Medicina Veterinária e Zootecnia, Universidade de São Paulo, São Paulo, 2004.

A síndrome de emagrecimento progressivo (SEP) dos calitriquídeos representa importante causa de morbidade e mortalidade de sagüis mantidas em cativeiro. A etiologia dessa síndrome não está estabelecida e suas principais características são emagrecimento progressivo, diarréia, colite, anemia, paralisia dos membros posteriores e alopecia. Com esse estudo pretende-se responder se a síndrome é um processo de má-absorção ou de desnutrição protéico-calórica primária, caracterizar o quadro histológico intestinal de base e a resposta imunológica tecidual local. Foram estudados três grupos de sagüis: 1) 40 doentes com SEP pertencentes ao criadouro Mucky, 2) 9 controles vivos sadios, 3) 8 necrópsias de controles sem SEP. Foi realizado acompanhamento clínico, exame laboratorial das fezes, teste de absorção de D-xilose, avaliação da composição nutricional e digestibilidade da dieta, estudo anatomopatológico, incluindo avaliação semiquantitativa e análise morfométrica do jejuno de sagüis que foram a óbito naturalmente por SEP e dos controles. Os resultados alcançados permitiram caracterizar o perfil dos animais acometidos no nosso meio; os sinais clínicos maiores e menores da síndrome; identificar esteatorréia; o comprometimento da função digestiva e absortiva do intestino delgado dos sagüis com SEP; caracterizar o quadro histopatológico como uma enterite com atrofia semelhante à doença celíaca humana. A associação dos resultados clínicos, laboratoriais e histológicos permitiu definir a SEP como processo de má-absorção, por perda de superfície absortiva de intestino delgado, decorrente de enterite crônica imunomediada, de padrão celíaco-like que leva a progressiva e grave desnutrição secundária dos animais acometidos.

Palavras-chaves: Patologia. Callitrichidae. Síndrome má-absorção animal. Intestino delgado. Primata. 


\begin{abstract}
SÁ. L.R.M. Wasting marmoset syndrome is a malabsorption process similar to celiac disease: clinical and pahology characterization [Síndrome de emagrecimento progressive dos calitriquídeos - processo de má abosrção semelhante à doença celíaca humana caracterização clínica, laboratorial e anatomopatológica.] 2004. 195f. Tese (Doutorado em Ciências) - Faculdade de Medicina Veterinária e Zootecnia, Universidade de São Paulo, São Paulo, 2004.
\end{abstract}

Wasting marmoset syndrome (WMS) is na important cause of morbidity and mortality of marmosets and tamarins kept in captivity. The etiology of this syndrome has not been established and its mais features are progressive weight loss, diarrhea, colitis, anemia, hind limb paralysis, and alopecia. The aims of this research were to demonstrate that WMS is a malabsorption process, and to analyze the underlying histological lesion of the intestine and to characterize the local immune response of the small intestine. The sick marmosets $(n=40)$ were compared to live normal controls $(n=9)$ or to necropsied marmosets that died of other diseases than WMS ( $\mathrm{n}=8)$, regarding clinical follow up, fecal analysis, D-xylose absorption test, evaluation of the nutritional composition and digestibility of the diet, gross and histological examination and morphometric approach of the jejune of wasters and control marmosets. These data revealed general features of WMS under our general captivity conditions, major and minor clinical signs of waster marmosets, impaired absorptive and digestive function of small intestine with steatorrhea and atrophic enteritis similar to celiac disease. The clinical and laboratory data associated with pathology examination demonstrated that WMS is a malabsorption process due to loss of absorptive surface area that results in progressive secondary malnutrition of the waster marmosets. The major immunological mechanism underlying the celiac-like enteritis of WMS is a T-cell immune mediated response that affects intestine architecture.

Key-words: Pathology. Wasting marmoset syndrome. Calltrichidae. Small intestine. Primate. 


\section{LISTA DE FIGURAS}

Figura 1 - Criadouro Mucky, vista lateral dos viveiros externos isolados.

Figura 2 - Criadouro Mucky, vista lateral dos viveiros justapostos em blocos.

Figura 3-Criadouro Mucky, vista lateral da área de cambeamento de um viveiro.

Figura 4 - Disposição das gaiolas, bandejas e anteparos utilizados para coleta de 57 urina e fezes de sagüis controles e sagüis doentes.

Figura 5 - Sistema de coleta da urina para a avaliação da função absortiva do intestino delgado de sagüis.

Figura 6 - Exemplo da metodologia usada para contagem dos pontos de intersecção no fragmento de jejuno de sagüis controles e sagüis com SEP, onde marcação em amarelo = área de vilo, em vermelho = área de criptas e em verde $=$ área de lâmina própria. Grade $=1 \mathrm{~mm}^{2}$.

Figura 7 - Exemplo da metodologia imuno-histoquímica (método estreptavidinabiotina-peroxidase) aliada a método morfométrico para contagem de células imunomarcadas/ $\mathrm{mm}^{2}$ em jejunos de sagüis. Marcação em vermelho $=$ células imunomarcadas.

Figura 8 - Sinal clínico maior da SEP: emagrecimento. Notar o posicionamento dos dígitos. Sagüis híbrido. Criadouro Mucky, São Paulo.

Figura 9 - Sinal clínico maior da SEP: emagrecimento. Notar perda de massa muscular do membro posterior. Sagüi-de-tufo-preto. Criadouro Mucky, São Paulo

Figura 10 - Sinal clínico maior da SEP: distensão abdominal. Sagüi-de-tufo-branco. 92 Criadouro Mucky, São Paulo

Figura 11 - Sinal clínico menor da SEP: alteração da marcha, posição em estação. 92 Sagüi híbrido. Criadouro Mucky, São Paulo 
Figura 12 - Sinal clínico menor da SEP: alteração da marcha, dismetria. Sagüi 92 híbrido. Criadouro Mucky, São Paulo

Figura 13 - Sinal clínico menor da SEP: alopecia da cauda. Sagüi-de-tufo-branco. 92 Criadouro Mucky, São Paulo

Figura 14 - Gotículas de gordura coradas por Sudan III nas fezes de sagüi com SEP， 93 exame coprológico. Esteatorréia

Figura 15 - Aspecto macroscópico de sagüi com SEP. Notar palidez dos órgãos e 93 distensão abdominal

Figura 16 - Aspecto macroscópico da dilatação das alças intestinais por conteúdo 93 pastoso e amarelado em sagüi com SEP

Figura 17 - Fotomicrografia do jejuno de sagüi com SEP. Enterite crônica difusa com atrofia de vilosidades, hiperplasia de criptas e infiltrado linfoplasmocitário na lâmina própria. HE , 40x

Figura 18 - Fotomicrografia do jejuno de sagüi com SEP. Enterite crônica com atrofia de vilosidades, hiperplasia de criptas e infiltrado linfoplasmocitário na lâmina própria. Notar atrofia das vilosidades. HE , 100x

Figura 19 - Fotomicrografia do jejuno de sagüi com SEP. Enterite crônica com atrofia de vilosidades, hiperplasia de criptas e infiltrado linfoplasmocitário na lâmina própria. Notar linfócitos intraepiteliais. HE , $200 x$

Figura 20 - Fotomicrografia do jejuno de sagüi com SEP. Enterite crônica, Enterite crônica com atrofia de vilosidades, hiperplasia de criptas e infiltrado linfo-plasmocitário na lâmina própria. Notar hiperplasia das criptas com aumento do número de mitoses. HE , 200x

Figura 21 - Fotomicrografia do jejuno de sagüi com SEP. Enterite crônica, infiltrado inflamatório linfo-plasmocitário observado na lâmina própria. HE , 400x

Figura 22 - Fotomicrografia do jejuno de sagüi com SEP. Imunomarcação para linfócitos B-CD20+. Estreptavidina-biotina-peroxidase contra corada por Hematoxilina de Harris. IHQ, 400x 
Figura 23 - Fotomicrografia do jejuno de sagüi com SEP. Imunomarcação para linfócitos T-CD45RO+. Estreptavidina-biotina-peroxidase contra corada por Hematoxilina de Harris. IHQ, 400x

Figura 24 - Fotomicrografia do jejuno de sagüi com SEP. Imunomarcação para linfócitos T-CD4+. Estreptavidina-biotina-peroxidase contra corada por Hematoxilina de Harris. IHQ, 400x

Figura 25 - Fotomicrografia do jejuno de sagüi com SEP. Imunomarcação para linfócitos T-CD8+. Estreptavidina-biotina-peroxidase contra corada por Hematoxilina de Harris. IHQ, 400x

Figura 26 - Fotomicrografia do jejuno de sagüi com SEP. Imunomarcação para células apresentadoras de antígeno, macrófagos CD68+. Estreptavidinabiotina-peroxidase contra corada por Hematoxilina de Harris. IHQ, 400x

Figura 27 - Fotomicrografia do jejuno de sagüi com SEP. Imunomarcação para células apresentadoras de antígeno, células dendrítica proteína S100+. Estreptavidina-biotina-peroxidase contra corada por Hematoxilina de Harris. IHQ, 400x

Figura 28 - Fotomicrografia do jejuno de sagüi com SEP. Imuno-expressão de 96 interleucina 2 (IL 2). Resposta imunomediada perfil TH 1. Estreptavidina-biotina-peroxidase contra corada por Hematoxilina de Harris. IHQ, 400x

Figura 29 - Fotomicrografia do jejuno de sagüi com SEP. Imuno- expressão de 96 interferon- $\gamma$ (IFN- $\gamma)$. Resposta imunomediada perfil TH 1. Estreptavidina-biotina-peroxidase contra corada por Hematoxilina de Harris. IHQ, 400x

Figura 30 - Fotomicrografia do jejuno de sagüi com SEP. Imuno-expressão de fator 96 de necrose tumoral (TNF- $\alpha$ ). Resposta imunomediada perfil TH 1. Estreptavidina-biotina-peroxidase contra corada por Hematoxilina de Harris. IHQ, 400x 


\section{LISTA DE GRÁFICOS}

Gráfico 1 - Distribuição dos sagüis com SEP (grupo I) segundo as espécies estudadas

Gráfico 2 - Distribuição dos sagüis com SEP (grupo I) segundo o sexo

Gráfico 3 - Distribuição dos sagüis com SEP segundo o local de nascimento

Gráfico 4 - Distribuição dos itens utilizados com maior freqüência na dieta dos sagüis do Criadouro Mucky durante os meses do ano 2000, segundo a média mensal

Gráfico 5 - Distribuição dos itens presentes em maior freqüência na $1^{\text {a }}$ refeição dos 73 sagüis do Criadouro Mucky

Gráfico 6 - Distribuição dos legumes presentes em maior freqüência na 2a refeição dos 73 sagüis do Criadouro Mucky

Gráfico 7 - Distribuição da carne de frango, ovos e macarrão presentes na $2^{\mathrm{a}}$ refeição 74 dos sagüis do Criadouro Mucky

Gráfico 8 - Distribuição das frutas mais freqüentemente presentes na $3^{\mathrm{a}}$ refeição dos 74 sagüis do Criadouro Mucky

Gráfico 9 - Teste de absorção de D-xilose em sagüis controles vivos (grupo II) e sagüis com SEP (grupo I)

Gráfico 10 - Alterações macroscópicas mais freqüentes nos casos de SEP

Gráfico 11 - Análise semiquantitativa da mucosa do jejuno dos sagüis controles (grupo

III) e sagüis com SEP (grupo I)

Gráfico 12 - Análise morfométrica da mucosa do jejuno nos sagüis controle (grupo III) 87 e sagüis com SEP (grupo I) 
Gráfico 13 - Distribuição das células inflamatórias imunomarcadas na lâmina própria 89 do jejuno de sagüis controles (grupo III) e sagüis com SEP, para os fenótipos proteína S100+, LB-CD20+, CD68+ e LT-CD45RO+

Gráfico 14 - Distribuição de LT-CD8+ e LT-CD4+ imunomarcadas na lâmina própria 90 do jejuno dos sagüis controles (grupo III) e sagüis com SEP (grupo I)

Gráfico 15 - Distribuição das citocinas presentes na lâmina própria do jejuno de sagüis 91 controles (grupo III) e sagüis com SEP (grupo I) 


\section{LISTA DE TABELAS}

Tabela 1 - Necessidades nutricionais estimadas para primatas não-humanos após o 20 desmame em relação à matéria seca, NRC 2003

Tabela 2 - Distribuição dos sagüis por grupo, segundo espécie, sexo, idade, local de 42 nascimento, tempo de cativeiro no Criadouro Mucky e peso

Tabela 3 - Itens alimentares utilizados na dieta dos 185 sagüis do Criadouro Mucky no ano de 2000, segundo o processamento, forma de apresentação e quantidades usadas por refeição

Tabela 4- Painel de anticorpos primários e sistemas de detecção utilizados nas reações 63 de imuno-histoquímica em jejuno de sagüis

Tabela 5 - Composição da dieta efetivamente consumida, sobre $100 \%$ da matéria 75 seca, pelos sagüis pertencentes ao Criadouro Mucky, durante 10 dias de experimento

Tabela 6 - Composição nutricional, sobre a matéria seca, da dieta originada do cálculo 76 de consumo médio de 10 sagüis durante os 10 dias de experimento

Tabela 7 - Coeficientes de digestibilidade aparente (\%) calculados para os sagüis 77 controles e com SEP

Tabela 8 - Sinais clínicos maiores e menores observados nos sagüis com SEP

Tabela 9 - Exame coprológico funcional das amostras de fezes dos sagüis com SEP 81 (grupo I) e sagüis controles (grupo II) 
Tabela 10 - Avaliação histopatológica semi quantitativa do jejuno dos sagüis com SEP (grupo I) e sagüis controles (grupo III), segundo relação vilo/ cripta, comprimento de vilo, grau de hiperplasia da cripta, intensidade do processo inflamatório, infiltrados mononuclear, neutrofílico, eosinofílico, número de linfócitos intraepiteliais em cada 100 enterócitos

Tabela 11- Análise morfométrica da mucosa do jejuno de sagüis com SEP (grupo I) e 86 sagüis controles (grupo III), segundo a densidade de volume (Vv) em área de vilos, área de criptas e lâmina própria

Tabela 12 - Resultados da contagem de células imunomarcadas por área $\left(\mathrm{mm}^{2}\right)$, quanto aos fenótipos proteína $\mathrm{S} 100+$, linfócitos B CD20+, linfócitos T CD45RO+, T CD8+, T CD4+ e imuno-expressão de interleucina 2, interleucina 4, fator de necrose tumoral- $\alpha$ e interferon $-\gamma$, segundo os casos de sagüi com SEP (grupo I) e sagüis controles (grupo III) 


\section{LISTA ABREVIATURAS}

DA Coeficiente de digestibilidade aparente

EE Extrato etéreo

ENN Extrativos não nitrogenados

FB Fibra bruta

HE Hematoxilina e eosina

ID Intestino delgado

IFN Interferon

IL2 Interleucina 2

IL4 Interleucina 4

LB Linfócito B

LT Linfócito T

MM Matéria mineral

MS Matéria seca

NK Células assassinas naturais

PB Proteína bruta

S100 Proteína S100

TCD4+ $\quad$ Linfócito T CD4+

TCD45RO+ Linfótico T CD45RO+

TCD8+ $\quad$ Linfótico T CD8+

TH1 Linfócito auxiliar do tipo 1

TH2 Linfócito auxilar do tipo 2

TNF Fator de necrose tumoral

tTG Transglutaminase tecidual 
1. INTRODUÇÃO

2. OBJETIVOS 3

3. REVISÃO DA LITERATURA 4

3.1. OS PRIMATAS 4

3.2. O PRIMATAS NEOTROPICAIS

3.2.1. Aspectos da classificação zoológica e conservação das espécies de primatas do 5 Novo Mundo

3.2.2. Importância biomédica dos primatas neotropicais

3.3. O GÊNERO CALLITHRIX

3.3.1. Aspectos gerais da biologia de interesse clínico e biomédico

3.3.2. Considerações sobre a dieta natural e o sistema digestivo do gênero Callithrix

3.4.1. A dieta no cativeiro: considerações sobre as necessidades nutricionais dos calitriquídeos

3.4.2. Considerações sobre os recintos e as doenças

3.5. A SÍNDROME DE EMAGRECIMENTO PROGRESSIVO

3.6. CONSIDERAÇÕES SOBRE A FISIOLOGIA DO INTESTINO DELGADO

3.7. DESNUTRIÇÃO E SÍNDROME DE MÁ-ABSORÇÃO 
4.1.3. Critérios de inclusão e exclusão

4.2. O CRIADOURO MUCKY

4.5.3.1. Exame de urina tipo I HISTOQUÍMICO 
5. RESULTADOS 
5.5.4. Análise da resposta imune no jejuno

6. DISCUSSÃ̃o

6.1. QUAL O PERFIL EPIDEMIOLÓGICO DOS SAGÜIS COM SEP EM NOSSO MEIO?

6.2. A DEFICIÊNCIA PROTÉICA-CALÓRICA É FATOR DESENCADEANTE DA 100 ENTEROPATIA?

6.3. COMO SUSPEITAR DE SEP A PARTIR DOS SINAIS CLÍNICOS?

6.4. A AVALIAÇÃO LABORATORIAL DAS FEZES PODE CONTRIBUIR PARA 108 CARACTERIZAÇÃO DA SEP?

6.5. PODERIA O TESTE DE ABSORÇÃO DE D-XILOSE CONTRIBUIR PARA CARACTERIZAÇÃO DA MÁ-ABSORÇÃO NA SEP?

6.6. HÁ ALTERAÇÕES NA EFICIÊNCIA DIGESTIVA NOS SAGÜIS COM SEP?

6.7. O EXAME MACROSCÓPICO CONTRIBUI PARA CARACTERIZAÇÃO DA SEP?

6.8. O EXAME HISTPATOLÓGICO DO INTESTINO DELGADO É ESSENCIAL PARA O DIAGNÓSTICO DA SEP?

6.9. VALIDAÇÃO DO MÉTODO IMUNO-HISTOQUÍMICO NO ESTUDO DA RESPOSTA IMUNE DA ENTEROPATIA DE SAGÜIS COM SEP

6.10. A CARACTERIZAÇÃO DA RESPOSTA IMUNE INTESTINAL PODE CONTRIBUIR PARA A PATOGENIA E CARACTERIZAÇÃO DA SEP?

\section{CONCLUSÕES}

REFERÊNCIAS

APÊNDICES

ANEXOS 


\section{INTRODUÇÃO}

Desastres ecológicos de dimensões inimagináveis, como derramamento de óleo em baías e manguezais, poluição em níveis alarmantes de lagoas e rios urbanos e hectares de matas em chamas, são problemas com significativas conseqüências ambientais. $\mathrm{O}$ crescimento dos centros urbanos e a resultante destruição de ecossistemas, como as florestas, entretanto, representa a maior ameaça para espécies vegetais e animais. Dentre as espécies animais ameaçadas destacam-se os platirrinos. O Brasil detém a maior diversidade de primatas neotropicais do mundo e apresenta $30 \%$ dos seus primatas ameaçados de extinção. Neste panorama, as estratégias para conservação de ecossistemas são fundamentais, incluindo o estabelecimento de áreas de proteção ambiental, criação de animais em cativeiro e planos de reintrodução de espécies ameaçadas.

Os zoológicos, os centros de primatologia e os criatórios conservacionistas desempenham importante papel como locais de preservação animal e como centros de estudo. Mesmo assim, continua o desafio de manter e reproduzir algumas espécies. As dificuldades não estão relacionadas somente a problemas de manejo e ocorrência de doenças infectoparasitárias. Especificamente, com relação aos calitriquídeos é descrita uma enfermidade de repercursão mundial, que causa elevada morbidade e mortalidade, referida em inglês como "wasting disease" ou "wasting marmoset syndrome", constituindo o que passamos a chamar de Síndrome de Emagrecimento Progressivo (SEP).

A SEP, apesar do tratamento preconizado e instituído, apresenta evolução longa e, freqüentemente, fatal. Para animais de laboratório representa um sério obstáculo nos ensaios 
experimentais, prejudicando a confiabilidade dos resultados e proporcionando gastos operacionais inesperados. Nas colônias de sagüis voltadas para preservação, está envolvida com baixos níveis de reprodução, falha no desenvolvimento dos filhotes e óbitos por processos secundários, bacterianos e fúngicos. Representa, além disso, um desalento ao clínico, uma vez que na maioria das vezes o óbito é inevitável.

Apesar do elevado número de casos relatados na literatura, a etiologia desta síndrome ainda não está estabelecida. De modo geral, quatro hipóteses causais são propostas: mánutrição, má-absorção, processo infeccioso e não adaptação ao cativeiro.

Considerando a importância, a atualidade e a complexidade da SEP, constatamos grandes lacunas no conhecimento dessa síndrome, e que várias questões não foram respondidads, entre as quais poderíamos ressaltar: Quais são os fatores desencadeantes? Quais seriam os indicadores de risco? Qual o perfil dos animais acometidos? Qual é a lesão anatomopatológica de base que a define?

O presente projeto foi elaborado buscando responder algumas dessas questões. Assim, esse trabalho visa a estudar sistematicamente as alterações clínico-laboratoriais e anatomopatológicas apresentadas pelos sagüis em cativeiro acometidos pela SEP, não deixando de avaliar as condições de criação dos calitriquídeos no Brasil em comparação com outros centros internacionais. 


\section{OBJETIVOS}

O objetivo geral deste estudo é contribuir para a compreensão da Síndrome de Emagrecimento Progressivo em calitriquídeos mantidos em cativeiro, buscando responder se a síndrome é um processo de má-absorção ou de desnutrição protéico-calórica primária, caracterizando o quadro histológico intestinal de base e a resposta imunológica local, visando um melhor entendimento da patogenia da enteropatia associada.

Para tanto, os objetivos específicos foram:

1. traçar o perfil dos sagüis acometidos pela SEP em nosso meio

2. avaliar a dieta oferecida no criadouro quanto a fonte de nutrientes e a composição nutricional

3. caracterizar o perfil clínico dos sagüis, categorizando os sinais clínicos maiores e menores, de acordo com a sua freqüência

4. verificar as alterações significativas do exame coprológico nos sagüis com SEP

5. verificar se há comprometimento primário funcional do pâncreas exócrino quanto à presença de tripsina fecal

6. avaliar a função absortiva do intestino delgado pelo teste de D-xilose

7. avaliar a eficiência digestiva de sagüis com SEP em comparação aos sagüis controles quanto à dieta padrão oferecida

8. caracterizar o comprometimento do intestino delgado quanto as suas alterações macro e microscópicas através de análise semiquantitativa e morfométrica da enteropatia

9. identificar e quantificar o fenótipo das células do infiltrado inflamatório presente na lâmina própria intestinal e caracterizar o perfil de expressão local de citocinas nos sagüis com SEP comparando-os com os controles 


\section{REVISÃO DE LITERATURA}

\subsection{OS PRIMATAS}

Segundo MITTERMEIER et al. (1994), existe cerca de 62 gêneros e 243 espécies de primatas, incluindo a espécie Homo sapiens, no mundo. O interesse pelos primatas nãohumanos não está restrito apenas a proximidade filogenética e semelhança com os seres humanos, mas também pelo fato dos primatas não-humanos serem importantes indicadores da biodiversidade das florestas (RYLANDS et al., 1997).

A taxonomia dos Primatas foi amplamente revisada no livro de GROVES (2001), quando foram sintetizados dados de biologia molecular e pesquisa filogenética das espécies de primatas, mostrando a relação taxonômica entre essas. No entanto, de acordo com o nosso entendimento a respeito da taxonomia dos Primatas, optamos por utilizar nesse trabalho a classificação descrita em ROWE (1996) e RYLANDS et al. (2000).

A ordem Primata é dividida em duas subordens: Prosimii e Anthropoidea (ROWE, 1996).

A subordem Prosimii, cujo nome significa "antes dos grandes macacos", apresenta morfologia semelhante aos primatas ancestrais com fósseis datando de 40 a 50 milhões de anos atrás (ROWE, 1996). Subdivide-se em duas infraordens: Lemuriformes e Tarsiiformes, a primeira englobando os lêmures e loris, que se distribuem respectivamente na Ilha de Madagascar, África e Ásia, e a segunda, os tarsiers que são encontrados nas ilhas do sudeste asiático (ROWE, 1996).

A subordem Anthropoidea é formada pelos verdadeiros primatas e pelos grandes macacos. Essa subordem se divide nas infraordens Platyrrhini, cujo termo significa "nariz 
achatado" e Catarrhini, cuja palavra significa "nariz redondo" fazendo alusão ao formato dos focinhos e posicionamento das narinas (NOWAK, 1991; ROWE, 1996).

Os antropóides se dividem em três superfamílias: 1- Ceboidea, composta pelos platirrinos, que compreende as famílias Callitrichidae e Cebidae; 2- Cercopithecoidea, macacos do velho mundo distribuídos na África e Ásia, e 3- Hominoidea, que é formada pelos gibões, grandes macacos e os homens, distribuídos no sudeste asiático, África e no mundo todo, respectivamente (ROWE, 1996). Os catarrinos correspondem as duas últimas superfamílias.

Os platirrinos estão distribuídos na região neotropical das Américas Central e do Sul (RYLANDS et al., 1997) e, assim, denominados de primatas neotropicais ou do Novo Mundo. A separação entre os catarrinos e platirrinos ocorreu há aproximadamente 26 a 27 milhões de anos atrás, e essa recente separação resultou em múltiplas diferenças entre esses dois grupos (MANSFIELD, 2003).

\subsection{OS PRIMATAS NEOTROPICAIS}

\subsubsection{Aspectos da classificação zoológica e conservação das espécies de primatas do Novo Mundo}

O conhecimento da diversidade dos primatas do Novo Mundo e sua distribuição fornece dados de extrema relevância que auxiliam na conservação dessas espécies, tanto em cativeiro, ex situ, como nos habitats naturais, conservação in situ. A importância da avaliação constante dessa diversidade é enfatizada pelo número crescente de espécies ameaçadas, que necessitam ter suas áreas específicas de distribuição priorizadas como áreas de proteção ambiental (RYLANDS et al., 1997). 
De forma geral, uma em cada quatro espécies de primatas estará em real perigo de extinção ao longo das próximas décadas e essas espécies ameaçadas são encontradas em todas as regiões de ocorrência (MITTERMEIER et al., 1994). No presente, o aumento de espécies de Primatas ameaçadas de extinção de 96 para 116 espécies se deve, na maior parte, a perda e degradação do habitat em decorrência da atividade agrícola, extrativista e do desenvolvimento industrial, à perda direta pela caça e pela coleta de exemplares vivos para o tráfico de animais e, também, à revisão da taxonomia (IUCN, 2000).

A taxonomia dos primatas do Novo Mundo é bastante discutida devido ao grande número de espécies da infraordem Platyrrhini. A publicação mais recente sobre o assunto está referendada no livro de GROVES (2001).

Os platirrinos dividem-se em cinco famílias (Callitrichidae, Cebidae, Aotidae, Pitheciidae e Atelidae), 18 gêneros, 110 espécies e 205 subespécies (RYLANDS et al., 2000).

A família Callitrichidae compreende seis gêneros, 41 espécies e 60 subespécies, cujos gêneros são Callimico, Mico, Callithrix, Saguinus, Cebuella e Leontopithecus. O gênero Mico passou a ser usado para designar os calitriquídeos que habitam a Amazônia (RYLANDS et al., 2000).

Os calitriquídeos, chamados popularmente de micos e sagüis, não apresentam a cauda preênsil e formam o grupo dos menores primatas neotropicais (NOWAK, 1991). O peso desses não chega a $1 \mathrm{Kg}(250$ a $600 \mathrm{~g})$, possuem garras em todos os dígitos, exceto pelos dedões dos pés, e a fórmula dentária é composta por 2/2 incisivos, 1/1 caninos, 3/3 prémolares, 2/2 molares em cada hemi-arcada, totalizando 32 dentes. Não apresentam dimorfismo sexual, são animais diurnos e arborícolas (NOWAK, 1991; RICHTER, 1984; ROWE, 1996).

A família Cebidae é formada por dois gêneros (Cebus e Saimiri) e 12 espécies; a família Aotidae compreende um gênero, Aotus, e oito espécies; a Pitheciidae tem quatro 
gêneros, Callicebus, Pithecia, Chiropotes e Cacajao, e 28 espécies. Por último, a família Atelidae, com cinco gêneros, Alouatta, Ateles, Logothrix, Oreonax, Brachyteles, e 21 espécies (RYLANDS et al., 2000).

As quatro famílias, descritas acima, formam um grupo diverso de primatas neotropicais de porte médio e grande, com peso superior a $1 \mathrm{Kg}$, com cauda preênsil em alguns gêneros, como Ateles, Brachyteles, Lagothrix, Oreonax e Alouatta. A fórmula dentária é $2 / 2$ incisivos, $1 / 1$ caninos, $3 / 3$ pré-molares e $3 / 3$ molares em cada hemi-arcada, totalizando 36 dentes (NOWAK, 1991; ROWE, 1996).

O Brasil detém a maior diversidade dos primatas neotropicais, pois é onde habitam 16 gêneros e 76 espécies distribuídas, principalmente, na Amazônia e Mata Atlântica (RYLANDS et al., 1997).

Considerando a população de platirrinos, RYLANDS e colaboradores (1997), revelaram que $19 \%$ dos gêneros e $34 \%$ das espécies de platirrinos estão ameaçadas. O Brasil, apesar de deter a maior diversidade de platirrinos, tem 30\% dos seus primatas ameaçados de extinção.

Na família Callitrichidae, as espécies Callithrix flaviceps, C. aurita, Saguinus oedipus, Leontopithecus rosalia, L. chrysomelas, L. chrysopygus, L. caissara são consideradas em perigo crítico (RYLANDS et al., 1997).

\subsubsection{Importância biomédica dos primatas neotropicais}

Nas últimas décadas os primatas neotropicais têm sido extensivamente utilizados em pesquisas biomédicas tanto no Estados Unidos da América (EUA) como na Europa, e esse fato se traduz primeiramente no aumento do número de publicações científicas relacionadas aos mesmos, nas últimas décadas (ABBOTT et al., 2003). Na Europa, a Inglaterra e a França 
são os países que se sobressaem na utilização de primatas não-humanos em protocolos experimentais. Como exemplo, em 2000, 2951 primatas não-humanos foram utilizados e destes, 1060 foram calitriquídeos usados em ensaios toxicológicos na Inglaterra (SMITH \& BOYD, 2003).

As questões éticas de utilização de primatas não humanos em protocolos experimentais são polêmicas (SMITH \& BOYD, 2003), mesmo quando se considera aceitável e evidente o benefício da manutenção dessas espécies no cativeiro em relação ao nosso ganho de conhecimento da biologia, nutrição e outros aspectos da história natural dos primatas não humanos.

Dentre as espécies de primatas neotropicais com demanda para pesquisas biomédicas incluem: mico-de-cheiro (Saimiri spp.), macaco-da-noite (Aotus spp.), micos (Saguinus spp.), sagüi-de-tufo-branco (Callithrix jacchus) e macaco-prego (Cebus apella) (MITTERMEIR et al., 1994).

Destacam-se as espécies Saguinus oedipus, como modelo para estudo de colites e carcinoma de cólon humano (CLAPP, 1993), e Callithrix jacchus, utilizado como modelo animal em pesquisas em neurociência; fisiologia da reprodução; doenças infecciosas virais; doenças parasitárias, como malária; toxicologia; desenvolvimento de drogas farmacêuticas; teratologia, odontologia e pesquisas de comportamento (modelos para ansiedade e estresse humano) (MANSFIELD, 2003; MITTERMEIR et al., 1994; PISSINATTI, 1993).

As razões para a crescente utilização biomédica do sagüi-de-tufo-branco são basicamente relacionadas ao tamanho dos animais, ao custo baixo de aquisição e manutenção, a sua fácil e eficiente reprodução, à particularidades fisiológicas e da biologia desses pequenos primatas (MANSFIELD, 2003; PISSINATTI, 1993).

A relevância desses fatos coloca o sagüi-de-tufo-branco, juntamente com mico-decheiro (Saimiri spp.) e o macaco-da-noite (Aotus spp.), como espécies de primatas 
neotropicais com proposta para o mapeamento genômico tendo como finalidade caracterizar seu potencial em pesquisas biomédicas de forma completa (EICHLER \& DeJONG, 2002).

Outro fator de importância, que contribui para o crescente uso de sagüi-de-tufo-branco é o fato dessa espécie não estar ameaçada de extinção no seu habitat natural (MITTERMEIR et al., 1994). Embora muitos dos exemplares usados sejam oriundos da criação em cativeiro de Centros Nacionais de Primatas e instituições acadêmicas, entre 1986 e 1990, cerca de 400 exemplares de sagüi-de-tufo-branco foram importados por criadores comerciais e companhias farmacêuticas americanas (MITTERMEIER et al., 1994; SMITH \& BOYD, 2003).

\subsection{O GÊNERO CALLITHRIX}

\subsubsection{Aspectos gerais da biologia de interesse clínico e biomédico}

O gênero Callithrix possui as espécies Callithrix jacchus (sagüi-de-tufo-branco), $C$. penicillata (sagüis-de-tufo-preto), C. kuhlii (sagüi-de-Weid), C. geoffroyi (sagüi-de-carabranca), C. aurita (sagüi-da-serra-escuro), e C. flaviceps (sagüi-da-serra) (RYLANDS et al., 2000). A caracterização fenotípica de cada espécie pode ser encontrada em EMMONS (1990) e NOWAK (1991).

O sagüi-de-tufo-branco é a espécie melhor conhecida e a única de importância biomédica no gênero Callithrix (MITTERMEIER et al., 1994).

Todas as espécies desse gênero apresentam tamanhos aproximados e são sexualmente monomórficos. O peso do indivíduo adulto varia de 250 a $450 \mathrm{~g}$ e os fillhotes nascem com peso médio de 30g; o tamanho médio do corpo do sagüi-de-tufo-branco, por exemplo, varia de 
190-250mm e o comprimento da cauda varia em torno de 270-350mm (EMMONS, 1990; PETERS \& GUERRA, 1998; STEVENSON \& RYLANDS, 1988).

As espécies desse gênero se distribuem pela costa leste e porção central da Mata Atlântica (RYLANDS et al., 1997). A distribuição de cada espécie pode ser encontrada em detalhes em GROVES (2001). É relevante saber que se distribuem em diferentes habitats como floresta atlântica, florestas do cerrado do Brasil central e caatinga do nordeste brasileiro, porém vivem predominantemente em áreas de matas ciliares que bordeiam os córregos nessas regiões (FARIA, 1989; RYLANDS, 1989). Do ponto de vista da ecologia dessas espécies, chama atenção à adaptação às áreas de florestas perturbadas (FARIA, 1989; RYLANDS, 1989).

Na natureza a área de uso do Callithrix é variável (FARIA, 1989) e para a espécie sagüi-de-tufo-branco, considera-se de 0,5 a 6,5 hectares com área de uso diário variando entre 500 a 1000 m (ROWE, 1996).

Os sagüis formam grupos sociais que variam de 3 a 15 indivíduos, compostos por adultos (machos e fêmeas) e a prole resultante de partos gemelares (FARIA, 1989). Por essa razão, os grupos quando assim compostos são denominados familiares estendidos (DIGBY \& BARRETO, 1993; FARIA, 1989; RYLANDS, 1989). O pai e os irmãos ajudam na criação e nos cuidados com os filhotes mais jovens (ARRUDA \& YAMAMOTO, 1991; RYLANDS, 1989; STEVENSON \& RYLANDS, 1988; YAMAMOTO, 1991). A composição do grupo na natureza pode ser alterada conforme os nascimentos e mortes dos filhotes durante os três primeiros meses de vida (DIGBY \& BARRETO, 1993; FARIA, 1989).

Vários autores consideram os sagüis monogâmicos, ocorrendo a formação de um único par, no qual uma fêmea se reproduz e há dominância e inibição da ovulação das demais fêmeas presentes no grupo (ABBOT, 1997; ALENCAR et al., 1995; RYLANDS, 1989). Porém, há relatos de comportamento social promíscuo em que se descrevem ocorrência de 
poliandria, poligenia e poliandrogenia, e, até mesmo, infanticídio, em grupos de sagüis mantidos no cativeiro e em vida livre (COUTINHO \& CORRÊA, 1995; DIGBY \& BARRETO, 1993; RODA \& PONTES, 1998; ROTHE \& KOENIG, 1991; RYLANDS, 1989).

Desta forma, as evidências mostram que o sistema de organização social dos Callithrix não está completamente estabelecido e a condição de cativeiro introduz possíveis alterações no seu comportamento social e reprodutivo. (YAMAMOTO, 1991).

No cativeiro, as espécies de Callithrix podem não apresentar sazonalidade reprodutiva, divergindo dos estudos no campo que mostraram o predomínio de nascimentos de julho a outubro e de dezembro a março (FARIA, 1989; STEVENSON \& RYLANDS, 1988). O intervalo entre partos é aproximadamente 5 a 7 meses, com ovulação após parto variando de 3 a 10 dias (STEVENSON \& RYLANDS, 1988; ROWE, 1996). O ciclo ovariano apresenta duração de 13 a 15 dias e a gestação, em média 144 dias (ROWE, 1996).

Dos primatas antropóides, as fêmeas de sagüis e micos são as únicas que rotineiramente apresentam ovulação de mais de um óvulo por ciclo ovariano, gerando em regra gêmeos dizigóticos (RICHTER, 1984; TARDIF et al., 2003). Porém, a gestação pode ser simples $(12,5 \%)$, gemelar $(62,5 \%)$, trigemelar $(21,4 \%)$ e quadrigemelar $(3,6 \%)$ (ROWE, 1996). Revisão recente a respeito da reprodução de sagüi-de-tufo-branco em cativeiro pode ser vista em TARDIF et al. (2003).

Os embriões dos sagüis estabelecem na placenta numerosas anastomoses vasculares ocasionando o desenvolvimento de indivíduos quimeras hematopoiéticos (NIBLACK et al., 1977). Esta particularidade tem despertado o interesse de vários pesquisadores, quanto a função imunológica dos calitriquídeos. Estudos in vitro demonstraram completa tolerância imunológica dos antígenos de histocompatibilidade entre gêmeos (JOHNSON, 1985; NIBLACK et al., 1977; PICUS et al., 1985). Entretanto, outros autores revelaram que o 
complexo de histocompatibilidade (MHC classe I e II) tem baixo polimorfismo e, portanto, esses animais apresentam maior susceptibilidade a agentes virais e bacterianos (ANTUNES et al., 1998; WATKINS et al., 1988).

Quanto ao desenvolvimento dos filhotes, o desmame acontece por volta dos dois meses de idade (STEVENSON \& RYLANDS, 1988); maturidade sexual, por exemplo, da espécie sagüi-de-tufo-branco, ocorre entre 12 e 18 meses e são considerados idosos a partir dos 8 anos de idade (ABBOTT et al., 2003). Relata-se que a longevidade dessa espécie pode chegar a 16 anos, em condição de cativeiro (NOWAK, 1991).

Os sagüis apresentam ritmo circadiano, em que as atividades seguem o padrão de duração de 10 a 12 horas, restrita ao período claro do dia (MOREIRA et al., 1991; YAMAMOTO, 1991). No cativeiro, a atividade se inicia logo após a alvorada (5 horas) ou ao ascender das luzes e termina por volta de 17/ 18 horas (MOREIRA et al., 1991; STEVENSON \& RYLANDS, 1988). A atividade diária, no cativeiro, é dividida em movimentação (35\%), "grooming” ou catação dos pelos (10\%), alimentação (12\%) e posição estacionária (53\%) (STEVENSON \& RYLANDS, 1988). O pico de atividade ocorre em torno das 11 horas e, geralmente, dormem ou descansam ao redor do meio dia e por volta das 15 horas em posição de decúbito esternal nos galhos (MOREIRA et al., 1991; YAMAMOTO, 1991).

A temperatura retal de sagüi-de-tufo-branco apresenta oscilação circadiana, com grau máximo durante o dia $\left(39.8^{\circ} \mathrm{C}\right)$, e temperatura mínima no período da noite $\left(34^{\circ} \mathrm{C}\right)$ (HETRERINGTON, 1978). Desta forma, merecem pronta atenção médica sagüis com temperatura muito elevada ou baixa durante o dia, e alteração no padrão de atividade diária. Outros parâmetros físicos, como freqüências cardíaca e respiratória, e valores laboratoriais de normalidade podem ser encontrados na literatura. (APRIL \& KEITH, 1998; JOHNSONDELANEY, 1994; MOORE, 2000; RICHTER, 1984; YARBROUGH et al., 1984). 


\subsubsection{Considerações sobre a dieta natural e o sistema digestivo do gênero Callithrix}

A primeira função do sistema digestivo é extrair energia e nutrientes essenciais do ambiente em que o animal vive de forma a suportar o processo metabólico (NRC, 2003). A maioria dos primatas não-humanos é frugívoro, mas não significa que a dieta é composta apenas de frutas. Geralmente, o consumo de frutas está associado ao consumo de invertebrados, vertebrados, ingestão de folhas, flores e exsudatos (NRC, 2003).

Os calitriquídeos são considerados, de forma geral, frugívoros-insentívoros, pois se alimentam de frutas, flores, exsudato de plantas, insetos, aranhas, lesmas, lagartos, sapos, filhotes e ovos de pássaros na natureza (STEVENSON \& RYLANDS, 1988). A ingestão de presas é em torno de $20 \%$ e os insetos representam uma fonte rica em energia, na forma de proteínas e gorduras (BARNARD \& KNAPKA, 1993; CRISSEY \& PRIBYL, 1997; NRC, 2003). Entretanto, as espécies pertencentes ao gênero Callithrix, como Callithrix jacchus e $C$. penicillata, se alimentam de grande quantidade de exsudato de plantas, chegando a representar 70\% da dieta destes animais na natureza (ROWE, 1996). Portanto, esses sagüis apresentam especialização e são considerados gomívoros-insentívoros (SCANLON et al., 1991; STEVENSON \& RYLANDS, 1988).

Sumariamente, os calitriquídeos também podem ser chamados de onívoros, devido à dieta ser composta por alimentos de origem animal e vegetal (OFTEDAL \& ALLEN, 1996).

As espécies de insetos, frutos, flores e árvores que compõem a dieta de sagüi-de-tufobranco e sagüi-de-tufo-preto na natureza foi descrita em detalhes por STEVENSON \& RYLANDS (1988). Dentre as árvores visitadas para alimentação, o cajueiro (Anacardium occidentalis) se destaca como uma das mais utilizadas pelas espécies citadas (STEVENSON \& RYLANDS, 1988). 
Os exsudatos de árvores conforme sua composição são denominados resinas ou gomas e são resultados de ferimentos ocasionados nos troncos e galhos (MACHADO \& LEITE, 1957). As resinas diferem das gomas por serem misturas insolúveis em água, mas solúveis em solventes orgânicos e, quando expostas ao ar, solidificam sob a forma de gotas ou lágrimas, enquanto as gomas são solúveis em água, se apresentam em estado coloidal e a consistência depende do tempo de exposição ao ar (COIMBRA-FILHO, 1972).

A goma do cajueiro é formada por $84 \%$ de carboidratos, entre os quais a arabina, que com hidrólise fornece arabinose e galactose, e vários minerais (1,05\%) incluindo ferro, alumínio, cálcio, potássio, sílica e traços de magnésio e sódio (MACHADO \& LEITE, 1957; COIMBRA-FILHO，1972; COIMBRA-FILHO \& MITTERMEIER，1976; COIMBRAFILHO \& MITTERMEIER, 1977). A utilização da energia oriunda da goma necessita de fermentação por microrganismos no intestino, uma vez que esse exsudato é resistente às enzimas digestivas dos mamíferos (POWER \& OFTEDAL, 1996).

O Callithrix apresenta particularidade anatômica e fisiológica interessante do sistema digestivo, embora o trato intestinal seja considerado estruturalmente com pouca especialização (NRC, 2003).

Com relação à dentição e mordedura, os sagüis desse gênero apresentam os caninos inferiores curtos e os incisivos inferiores longos, e esse padrão de mordedura foi denominado "mordedura curta", característica que difere o gênero em questão dos gêneros Saguinus e Leontopithecus, que possuem caninos inferiores longos, denominados calitriquídeos com "mordedura longa" (COIMBRA-FILHO, 1972; COIMBRA-FILHO \& MITTERMEIER, 1976).

Dotados dessa particular mordedura, os sagüis são capazes de perfurar a casca e fazer buracos em troncos e galhos de árvores, o que possibilita acesso à goma como fonte de alimento (COIMBRA-FILHO, 1972). Os buracos ocasionados são, ainda, locais onde urinam 
e esfregam as regiões suprapúbica ou circungenitais deixando marcas de cheiro importantes para o comportamento intra-grupo (COIMBRA-FILHO \& MITTERMEIER, 1976; SCANLON et al., 1991).

Quanto à anatomia do trato intestinal do sagüi-de-tufo-branco, alguns autores abordaram como CATON et al. (1996), que descreveram o estômago de sagüis-de-tufobranco como a região de maior capacidade do trato intestinal $(51,5 \%)$ em termos de peso de conteúdo úmido, por apresentar comprimento médio de $6,7 \mathrm{~cm}$ e capacidade média de $17 \mathrm{~g}$.

O intestino delgado apresenta duodeno em forma de "J" e são poucas as alças do jejuno e íleo, totalizando em média $49 \mathrm{~cm}$ (63\%) do comprimento do trato intestinal (CATON et al, 1996; MIRAGLIA et al., 1967). O intestino grosso possui calibre maior e apresenta disposição das alças em "U” invertido, incluindo o ceco ( $6 \mathrm{~cm}$ de comprimento), o cólon com as porções ascendente, transversa e descendente ( $18 \mathrm{~cm}$ de comprimento) e o reto que termina no canal anal, ressaltando que não possuem apêndice vermiforme (CATON et al, 1996; MIRAGLIA et al., 1967).

O ceco e cólon são segmentos bastante desenvolvidos, onde o ceco representa $35 \%$ da capacidade e $25 \%$ do comprimento total do intestino grosso, e os autores consideram essa particularidade uma resposta adaptativa à ingestão de alimentos que necessitam fermentação microbiana, como os exsudatos (CATON et al., 1996; FERRARI \& MARTINS, 1992; FERRARI et al., 1993; POWER \& OFTEDAL, 1996).

A ingestão de goma pelos sagüis exsudatívoros, Callithrix jacchus e Cebuella pygmae, ocasiona aumento do trânsito intestinal (tempo de passagem do alimento da boca ao ânus), porém sem alteração na eficiência digestiva da matéria seca da dieta. $\mathrm{O}$ mesmo não ocorre com espécies de sagüis frugívoros, como Saguinus oedipus e Leontopithecus rosalia, em que não há alteração do trânsito intestinal, mas a eficiência digestiva está diminuída na presença de goma (POWER \& OFTEDAL, 1996). 
CATON et al. (1996) descreveram que C. jacchus apresenta duas estratégias digestivas que otimizam o aproveitamento da energia advinda do alimento: 1- digestão rápida dos alimentos de alta qualidade, como insetos e frutas, ao longo do intestino delgado, 2retenção seletiva no ceco de polissacarídeos solúveis, dos exsudatos, bactérias e alimentos muito pequenos, provenientes do exo-esqueleto de insetos. Esta adaptação permite grande flexibilidade na capacidade de conseguir os nutrientes necessários dos alimentos, tanto na natureza como no cativeiro. Algumas espécies, mesmo sendo gomívoras, apresentam estado nutricional adequado, mesmo quando no cativeiro não tem acesso aos exsudatos de plantas (KANPKA et al., 1995).

Particularidades da anatomia do sistema digestivo de outras espécies de calitriquídeos foram descritas por FERRARI \& MARTINS (1992) e FERRARI et al (1993).

A estrutura histológica do trato intestinal dos sagüis-de-tufo-branco não difere de outros primatas e consiste das camadas: mucosa, submucosa, muscular interna, muscular externa e membrana serosa. A mucosa inclui o epitélio, a lâmina própria e a muscular da mucosa. O intestino delgado apresenta vilosidades, que são longas, afiladas e freqüentemente exibem os ápices bífidos (MIRAGLIA et al., 1967; STERNBERG, 1998).

\subsection{MANUTENÇÃO DE CALITRIQUÍDEOS NO CATIVEIRO}

\subsubsection{A dieta no cativeiro: considerações sobre as necessidades nutricionais dos calitriquídeos}

A manutenção de algumas espécies de primatas no cativeiro ainda apresenta desafio, principalmente em proporcionar boa nutrição (CRISSEY \& PRIBYL, 1997). O bem-estar de 
primatas não-humanos em cativeiro é dependente da dieta utilizada, de forma que essa garanta os nutrientes necessários, propicie comportamento de se alimentar e função digestiva normais (NRC, 2003).

A dieta no cativeiro geralmente difere significantemente da dieta na natureza (LAYNE \& POWER, 2003). Os critérios que são considerados e comparados para indicar que uma colônia de calitriquídeos apresenta condições adequadas de manejo, incluindo a dieta, estão relacionados com o desempenho reprodutivo e sobrevida dos filhotes como os seguintes índices: intervalo entre partos; duração da gestação; número de filhotes por nascimento; freqüência de nascimentos no ano; número de natimortos; número de óbitos durante o período perinatal e número de óbitos após o desmame (PETERS \& GUERRA, 1998; POOLE \& EVANS, 1982; TARDIF et al., 1984).

Os calitriquídeos são considerados espécies exigentes quanto à alimentação (COIMBRA-FILHO \& MAIA, 1977; BARNARD \& KNAPKA, 1993). No cativeiro, várias formulações de dieta têm sido utilizadas, tais como as propostas por COIMBRA-FILHO et al. (1981), CLAPP \& TARDIF (1985) e TARDIF et al (1988).

Segundo MORIN (1985), a dieta é uma variável importante na manutenção de calitriquídeos em cativeiro e, muitas vezes, de difícil avaliação, controle e reprodutibilidade.

O estado nutricional representa o fator de maior influência no crescimento, reprodução e longevidade de primatas não humanos, bem como na capacidade desses animais resistirem a agentes patogênicos e ao estresse ambiental (KNAPKA et al., 1995; OFTEDAL \& ALLEN, 1996).

O processo de fornecer aos primatas não-humanos dietas adequadas depende do estabelecimento das necessidades nutricionais básicas de, aproximadamente, 50 nutrientes essenciais para cada espécie, nos diversos momentos do ciclo da vida destes animais (KNAPKA et al., 1995). Além desta dificuldade inicial, outros fatores influenciam na 
qualidade da dieta, como bioviabilidade dos nutrientes, palatabilidade e aceitação pelos animais (COIMBRA-FILHO et al., 1981; FLURER et al, 1983; TARDIF et al., 1988; KNAPKA et al., 1995).

Segundo KNAPKA e colaboradores (1995), a necessidade nutricional dos primatas não-humanos é dinâmica e é influenciada por fatores genéticos e ambientais.

As fontes de carboidratos, gorduras e proteínas fornecem a energia diária a ser consumida. Os calitriquídeos necessitam de 3,9-4,2 Kcal energia/ g de dieta (CLAPP \& TARDIF, 1985), ou $335 \mathrm{Kcal}$ de energia disponível por kg de peso por dia (BARNARD et al., 1988).

Os platirrinos são considerados primatas que necessitam de níveis elevados de proteína na dieta (COIMBRA-FILHO, 1977). Sugerem-se valores em torno de $20 \%$ de proteína (CLAPP \& TARDIF, 1985). FLURER \& ZUCKER (1988) relataram que os animaoácidos essenciais para Callithrix jacchus são arginina e histidina.

A gordura, por sua vez, é importante componente da dieta devido ao elevado teor calórico, além de ser fonte de ácidos graxos essenciais. As dietas comerciais para primatas do Novo Mundo, geralmente, contêm 9\% de gorduras (KNAPKA et al., 1995). Com relação às fibras vegetais, a necessidade dietética de fibras não foi estabelecida para os primatas nãohumanos (KANPKA et al., 1995). Entretanto, estudos experimentais postulam 4,2-10\% de fibras nas dietas de calitriquídeos (CLAPP \& TARDIF, 1985).

Quanto às vitaminas, os calitriquídeos, dentre os primatas, necessitam de dietas com elevados níveis de vitamina $\mathrm{D}_{3}, 1000$ a $3000 \mathrm{UI}$ de vitamina $\mathrm{D}_{3} / \mathrm{Kg}$ de MS; níveis de vitamina $\mathrm{E}>95-130 \mathrm{mg} / \mathrm{Kg}$ de $\mathrm{MS}$, e vitamina $\mathrm{C}, 500 \mathrm{mg} / \mathrm{Kg}$ de MS (NRC, 2003). Os minerais, com exceção do iodo $(0,65 \mathrm{mg} / \mathrm{kg})$, não têm os valores mínimos determinados no NRC (2003).

Nos EUA e Europa a utilização de dieta específica para calitriquídeos tem sido empregada há várias décadas. A avaliação da eficácia na criação de sagüis e micos com o uso 
de dietas comerciais foi realizada por ESCAJADILLO et al. (1981); WIRTH \& BUSELMAIER (1982); FLURER et al. (1983); TARDIF et al. (1988).

Segundo DEINHARDT (1970), a primeira descrição de dieta oferecida no cativeiro é composta por mistura de cereais para crianças; leite-em-pó integral; germe-de-trigo e suplemento mineral e vitamínico servidos na consistência pastosa. Dessa dieta original, variações foram formuladas e foram acrescidas de ração peletizada para macacos nãohumanos.

A dieta usada no Centro de Primatologia do Rio de Janeiro, comprovadamente com excelentes resultados (LEITE, 2002; PISSINATTI, 1993) foi inicialmente descrita na literatura em 1977 por COIMBRA-FILHO \& MAIA. Os itens que a compõem são pão-detrigo integral, frutas da época e banana, leite-em-pó integral, gema de ovos, suplementos vitamínicos e minerais, ração comercial para cães, larvas de tenébrios e hortifrutigranjeiros (LEITE, 2002).

No Centro de Biologia da Reprodução, Universidade Federal de Juiz de Fora, Minas Gerais, a dieta utilizada consistia de leite, ovos, vegetais (cenoura e beterraba), banana, ração para cães (15-20 mg/ dia/ animal) e Farinha-Láctea $\left(\right.$ Nestlé $\left.{ }^{\circledR}\right)$ acrescidas de Aderogil $\mathrm{D}_{3}{ }^{\circledR}$ (1200UI/ animal/ semana) (PETERS \& GUERRA, 1998).

Em nosso país predomina o uso de dietas preparadas no próprio estabelecimento, seja centro de primatologia, zoológicos, criadores consevacionistas ou comerciais. A utilização dos itens é dependente da disponibilidade dos mesmos quanto ao custo e sazonalidade do alimento. Em outros países, embora o comum seja a utilização de dietas industrializadas e com comprovação de eficiência na criação, as mesmas não impedem o desenvolvimento de doenças como a síndrome de emagrecimento progressivo.

No NRC (2003), as necessidades nutricionais para os calitriquídeos não foram inteiramente definidas, mas somente estimada para alguns nutrientes. As necessidades 
nutricionais, em relação a MS, para primatas não-humanos foram estimadas de forma a garantir a manutenção, reprodução e o crescimento de jovens desmamados. Os itens comumente usados incluem grãos e seus subprodutos, farinha de sementes oligenosas, farinha de forragens, subprodutos de origem animal, óleos, gorduras, fontes de cálcio e fósforo, sal e premix de vitaminas e minerais (NRC, 2003).

Na tabela 1 são encontradas as necessidades nutricionais estimadas para primatas nãohumanos apresentadas no NRC, 2003.

Tabela 1 - Necessidades nutricionais estimadas para primatas não-humanos após o desmame em relação à matéria seca, NRC 2003

\begin{tabular}{lc}
\hline NUTRIENTE & $\begin{array}{c}\text { Concentraçã } \\
\text { o }\end{array}$ \\
\hline Proteína bruta, \% & $7^{1}-18^{1}$ \\
Fibra detergente ácido, \% & $5^{1}$ \\
Energia metabolizável kcal/g & 4 \\
Cálcio, \% & 0,8 \\
Fósforo total, \% & 0,6 \\
Magnésio, \% & 0,08 \\
Potássio, \% & 0,4 \\
Sódio, \% & 0,2 \\
Cloro, \% & 0,2 \\
\hline
\end{tabular}

${ }^{1}$ valores propostos para calitriquídeos 


\subsubsection{Considerações sobre os recintos e as doenças}

O conhecimento da biologia básica e dos parâmetros fisiológicos das espécies permite o acompanhamento clínico e a avaliação periódica das condições de manutenção dos sagüis no cativeiro. O tamanho, a forma e a complexidade dos recintos são importantes fatores na criação de calitriquídeos em ambiente de laboratório ou de zoológicos (KITCHEN \& MARTIN, 1995).

Diversos trabalhos abordam a criação de calitriquídeos e descrevem os recintos e a ornamentação dos mesmos com o objetivo de serem práticos, proporcionarem bem-estar aos animais e alcançarem índices reprodutivos adequados, ou seja, 3 a 5 filhotes por ano (IGRAM, 1975; STEIN et al., 1979; PEREIRA \& MELO, 1983; ELY et al., 1997; RICHTER, 1984; TARDIF et al., 1984; CLAPP \& TARDIF, 1985; LAYNE \& POWER, 2003).

Para PISSINATTI (1993), os recintos variam de tamanho, dependendo da espécie, dos recursos, do espaço disponível, da técnica empregada e, por fim, do objetivo a que se pretende criando calitriquídeos. Sugere recintos grandes para reprodução, mas no caso da criação individual, viveiros de $1,0 \times 0,7 \times 0,7 \mathrm{~m}$, quanto ao comprimento, altura e largura.

As normas para aquisição, cuidados e utilização experimental desses primatas podem ser encontradas no guia internacional da Sociedade de Primatologia Internacional (IPS INTERNATIONAL GUIDELINES FOR THE ACQUISITION, CARE AND BREEDING OF NONHUMAN PRIMATES, 1989/1993). As recomendações para monitoramento da saúde desses animais em cativeiro, com intuito de garantir animais saudáveis e minimizar os fatores que possam interferir nos resultados científicos foram abordadas pela "Federation of European Laboratory Animal Science Associations (FELASA)” (WEBER et al., 1999).

Para POTKAY (1992), a condição de cativeiro e confinamento de calitriquídeos implica alteração da dieta, temperatura, umidade, mudança no grupo social, exposição a 
espécies animais e a agentes infecto-parasitários diferentes, que poderiam ocasionar o aparecimento de doenças.

As descrições das principais doenças infecto-parasitárias e outras que acometem os calitriquídeos mantidos em cativeiro podem ser encontradas em vários trabalhos, dentre esses BRACK \& ROTHE (1981); DIAS et al. (1996); DINIZ \& COSTA (1995); DUBOIS (1996); EPIPHANIO (1997); GIBSON (1998); GOZALO \& MONTOYA (1991a), LEITE (2002); LOWESTINE (1986); LUDLAGE \& MANSFIELD (2003); MANSFIELD \& KING (1998); MIGAKI (1986); MONTALI \& BUSH (1998); POTKAY (1992); SÁ (1999); SCOTT (1992), e TOFT \& EBERHARD (1998).

\subsection{A SÍNDROME DE EMAGRECIMENTO PROGRESSIVO}

A Síndrome de Emagrecimento Progressivo (SEP) foi pela primeira vez apontada como uma enfermidade de alta morbidade e mortalidade em 1976 (RICHTER, 1984). É caracterizada por perda de peso progressiva, alopecia da cauda e grave atrofia muscular, diarréia crônica e colite crônica acometendo apenas calitriquídeos mantidos em cativeiro (MORIN, 1983). Esta entidade é, usualmente, associada a diferentes alterações clínicolaboratoriais como à anemia, presença ou não de corpúsculos de Heinz, hipoproteinemia, hipoglicemia, hipotermia, deficiência de vitaminas e minerais, diarréia crônica, paralisia dos membros posteriores, parasitismo de ducto pancreático, nefropatia crônica e alteração da composição da microbiota intestinal (CHADWICK et al., 1979; SHIMWELL et al., 1979; BRACK \& ROTHE, 1981a; MCNEES et al., 1983; HAWKEY, 1984; RICHTER, 1984; MORIN, 1985; HAWKEY, 1986; LEWIS et al., 1987; BEGLINGER et al., 1988; FLURER \& ZUCKER, 1988; POTKAY, 1992). 
A SEP que acomete os calitriquídeos assemelha-se clinicamente a processos que em humanos são decorrentes de grave má-nutrição protêica-calórica e a síndromes de máabsorção, como doença celíaca e intolerância à lactose (RILEY, 1993; KANE \& KUMAR, 1999).

Para POTKAY (1992), a SEP não é uma síndrome ou doença específica devido a grande variedade de fatores que podem desencadear ou influenciar o seu aparecimento. Por sua vez, SHIMWELL et al. (1979) consideram que a SEP não está relacionada com o baixo peso ao nascimento, ao grau de parentesco ou a susceptibilidade similar em gêmeos. MURGATROYD \& CHALMERS (1980) consideram a SEP uma doença sem caráter hereditário, por acometer animais de diferentes idades. Segundo RICTHER (1984), SEP deve ser sempre considerada quando o peso de animais adultos caiu abaixo do valor normal sem causa definida.

Em estudo anteriormente realizado, foi constatado que animais jovens, adultos, machos e fêmeas, foram acometidos pela SEP, de forma semelhante tendo a perda de peso chegado a mais de $50 \%$, daquela esperada para a espécie. Entretanto, do grupo de animais acometidos, quatro, apresentavam grau de parentesco próximo, ou seja, eram pais e filhotes, e dois dividiam o recinto com os anteriores. Poder-se-ia assim considerar, que nesse grupo de animais o fator genético tenha contribuído no desenvolvimento da SEP (SÁ, 1999).

Dentre as características anátomo-clínicas da SEP foram apontados quadros de SEP de duração variável, iniciados com diarréia e isolamento de Campylobacter sp.e progressão para o óbito, apesar do tratamento instituído e da melhora do distúrbio entérico, além de anemia, enteropatia, atrofia muscular e infecções oportunistas (BRACK \& ROTHE, 1981; RICHTER, 1984; MORIN, 1985; CHALIAFOUX et al., 1982; SÁ, 1999).

Segundo RICTHER (1984), é comum associar anemia de origem desconhecida a SEP. As deficiências de vitamina $\mathrm{E}$ e selênio têm sido consideradas como hipóteses para o 
desenvolvimento de anemia e alterações musculares na SEP (BASKIN et al., 1983; JUANSALLÉS et al., 1998; JUAN-SALLÉS et al., 2003). MURGATROYD \& CHALMERS (1980), valendo-se da técnica histológica e da histoquímica, mostraram que as fibras musculares atróficas remanescentes eram do Tipo II e as normais eram do Tipo I nos casos com SEP, sendo essas alterações compatíveis com hipovitaminose E. Há controvérsia se a hipovitaminose E é decorrente da dieta inadequada ou devido à má-absorção (BASKIN et al., 1983; KING, 1993; JUAN-SALLÉS et al., 1998; JUAN-SALLÉS et al., 2003).

No estudo de SÁ (1999), a enterocolite linfoplasmocítica difusa com atrofia das vilosidades em graus variados foi comum a todos os animais. Estas alterações diferem das lesões agudas causadas por Campylobacter (RUSSELL, 1993; BRADY \& MORTON, 1998), da colite crônica observada por alguns autores nos casos de SEP (CHALIFOUX et al., 1982; CHALIFOUX et al., 1993; SAINSBURY et al., 1987), dos processos inflamatórios crônicos intestinais - colite ulcerativa e doença de Crohn - descritos no homem (RIDDELL, 1985) e da colite crônica relatada no sagüi-de-topete-branco (LUSHBAUGH et al., 1985).

Contudo, a lesão entérica observada por SÁ (1999), de forma geral, se assemelha à descrita nos macacos da noite com deficiência de vitamina E (KING, 1993), ao caso de diarréia crônica idiopática descrita em gorila (Gorilla gorilla) (MOLTENI et al., 1980), ao processo de má-absorção em macaco rhesus (Macaca mulatta) (HARRIS et al., 1984), a enterite linfocítica plasmocítica idiopática dos cães (TAMS, 1987) e a, observado em pacientes humanos com marasmo, Kwashiorkor e doença celíaca (CRAWFORD, 1999; KANE \& KUMAR, 1999; MÄKI \& COLLIN, 1997).

PEÑA \& CRUSIUS (1998) afirmam que insultos diferentes podem produzir reação histopatológica intestinal semelhante, porém com expressões clínicas distintas. Nos casos com SEP, o exame clínico laboratorial sistemático pode vir a contribuir para o esclarecimento desta enfermidade. 
CHALIFOUX et al. (1993) afirmam que as colites observadas nos sagüis-de-topetebranco com SEP são sugestivas do envolvimento de agentes infecciosos. Nos calitriquídeos agentes infecciosos bacterianos e virais, como Campylobacter (MOORE, 1985; RUSSELL et al., 1985) e o vírus assemelhado ao coronavírus (RUSSELL et al., 1985), foram abordados como agentes etiológicos de colites crônicas e de SEP, mas ainda existe controvérsia nessa associação agente-enteropatia. No trabalho de SÁ (1999), apesar da maioria ter apresentado inicialmente diarréia e isolamento de $C$. jejuni nas fezes colhidas no recinto, somente um dos animais teve isolamento de $C$. coli a partir de material colhido na necrópsia. Ressalta-se que esse indivíduo não apresentou diarréia, mas tão somente emagrecimento. Conseqüentemente, é possível que o Campylobacter spp. tenha contribuído não só como fator desencadeante, mas também tenha perpetuado de alguma forma as alterações, mesmo estando estes indetectáveis na cultura microbiológica. BROWN (1985), estudando a relação de infecção ou presença de Campylobacter com processos inflamatórios crônicos intestinais no homem, foi incapaz de detectar qualquer infecção, anticorpo ou antígeno de Campylobacter spp. na sua amostragem.

Segundo SÁ (1999), o envolvimento de mais de um indivíduo da mesma família e o fato de todos pertencerem ao mesmo recinto, associado à presença de lesão entérica, sugere um comportamento familiar e imunológico nessa entidade. CHALIFOUX et al. (1993) apontaram a possibilidade de ocorrer reposta autoimune semelhante a observado na relação enxerto verso hospedeiro, devido às características particulares do sistema imune destes animais, ou uma resposta imune aos componentes da dieta, como pode ser observado nas colites induzidas por carraginina.

BARKER \& DREUMEL (1993) relaciona a enterite linfoplasmocítica com a síndrome de má-absorção e hipoproteinemia em várias espécies de animais. A síndrome de má-absorção nos primatas não humanos pode estar relacionada a enteropatia, mas, também, à lesão pancreática. BEGLINGER et al. (1988) relacionaram o quadro clínico de SEP observado em 
sagüi-de-tufo-branco com insuficiência pancreática exócrina decorrente do intenso parasitismo por Trichospirura leptostoma nos ductos pancreáticos destes animais.

BARNARD et al. (1988) consideram que as alterações clínicas e laboratoriais da SEP são consistentes com deficiência protêica-calórica, sendo a dieta inadequada a variante primordial para determinação desse quadro e que esse processo seria reversível com a alteração ou melhora da dieta.

Nos animais estudados por SÁ (1999) com SEP foi freqüente (quatro indivíduos) a queixa de paralisia progressiva dos membros posteriores evoluindo para os anteriores. Estas alterações locomotoras foram consideradas pela autora como sendo secundária a severa atrofia muscular generalizada, o que dificultaria a extensão e flexão dos membros. MURGATROYD \& CHALMERS (1980) não observaram lesões nos nervos periféricos ou no sistema nervoso central dos animais com SEP. Contudo, OLKOWSKI \& MANOCHA (1972) e MANOCHA (1973) verificaram desmielinização em neurônio motor espinhal e em gânglios nervosos periféricos em micos-de-cheiro alimentados com dietas compostas com $2 \%$ de proteína.

Segundo CHANDRA (1981) a má-nutrição é a causa mais comum de imunodeficiência, proporcionando altas taxas de mortalidade e morbidade decorrentes de doenças infecciosas. No trabalho de SÁ (1999), dos seis casos com SEP dois exibiram infecção terminal por cocos Gram-positivos e um desenvolveu candidíase sistêmica.

RICTHER et al. (1984) postulou que problemas de comportamento, aliados à dieta inadequada podem ocasionar SEP. DROSSMAN (1985) menciona que o estresse e fatores comportamentais estão associados ao desenvolvimento de doenças crônicas intestinais, como o carcinoma de cólon. A possibilidade do criatório apresentar problemas de adaptação e dificuldade de ajuste social entre os grupos de sagüis foi ponderada, uma vez que os recintos possibilitavam contatos visual, olfativo e auditivo entre os grupos (SÁ, 1999). Nos casos 
analisados, os dois animais jovens exibiram involução precoce do timo, sendo esta uma das lesões encontradas em situação de estresse (SZABO, 1985).

SCHROEDER et al. (1999) pesquisaram a presença de anticorpos IgA anti-gliadina, IgA anti-imune complexos circulantes e depósitos de IgA no glomérulo de sagüis com sintomas de SEP e mostraram aumento desses anticorpos no soro desses animais. Os resultados alcançados por esses autores sugeriram que os anticorpos anti-gliadina estariam envolvidos na etiologia e patogênese da doença crônica gastrointestinal e /ou renal dos sagüis com SEP. Em estudo paralelo, os autores mostraram envolvimento de anticorpos IgA antigliadina na nefropatia descritas em calitriquídeos e caracterizaram como nefropatias por deposição de IgM e IgA (BRACK et al., 1999).

A dieta como uma das possíveis etiologias da SEP tem sido arrolada por vários autores (MORIN, 1985; BARNARD et al., 1988; BRACK \& ROTHE, 1981b; SCHROEDER et al., 1999) e recentemente foi demonstrado que os calitriquídeos apresentam sensibilidade a alguns itens da dieta, como o trigo (GORE et al., 2001).

JUAN-SALLÉS (1998), corroborado por SÁ (1999), sugere que o exame clínicolaboratorial, a análise nutricional da dieta e o exame anatomopatológico dos sagüis com SEP podem auxiliar no esclarecimento das alterações apresentadas pelos indivíduos acometidos por essa síndrome.

\subsection{CONSIDERAÇÕES SOBRE A FISIOLOGIA DO INTESTINO DELGADO}

Nas últimas décadas, vários estudos proporcionaram a consolidação dos conhecimentos sobre morfologia e função do ID, ressaltando abordagem dinâmica entre 
forma e função a partir das investigações sobre os mecanismos de digestão e absorção integrados a citodinâmica do enterócito (MARTINS CAMPOS, 1993).

O intestino delgado apresenta várias funções gerais, tais como: secreção, digestão, absorção, metabolização e transporte de nutrientes do estômago ao cólon, secreta hormônios, desempenha papel de barreira mecânica à presença de agentes e de agressões externas presentes na luz do trato gastrintestinal, e desenvolve uma potente e especializada resposta imune (THOMPSON, 1995).

O ambiente físico-químico do intestino delgado determina como os nutrientes são absorvidos e como patógenos potenciais são evitados e, portanto, a habilidade de controlar esse espaço é fundamental à vida. Durante o processo evolutivo das espécies, a interiorização da superfície absortiva e o controle dos mecanismos envolvidos na absorção propiciaram a especialização e seleção dos indivíduos multicelulares e, conseqüentemente, da "vida inteligente" (SANDERSON, 1999).

A manutenção do ambiente favorável à vida está baseada no controle da complexa interação entre nutriente, microbiota bacteriana, peristaltismo e secreções do ID por meio de adaptações estruturais e microestruturais, que foram selecionadas durante a evolução das espécies (SANDERSON, 1999). O conhecimento da função e da estrutura do ID é fundamental para o entendimento das doenças intestinais e revisão detalhada da anatomia e histologia desse segmento pode ser encontrada em GUYTON \& HALL (1994); GANONG (2000); MADARA \& TRIER (1994).

Entre os fenômenos adaptativos do ID, os desdobramentos para a ampliação da superfície absortiva recebem destaque em importância e são subdivididos em quatro tipos de adaptação: 1- elongação tubuliforme da alça intestinal (amplia superfície em 1x), 2pregueamento de Kerkring (aumenta em 3x a superfície tubular), 3- vilogênese (amplia em 10x), 4- microvilogênese (em 20x), propiciando área absortiva de aproximadamente 600x 
maior que a superfície tubular inicial. No homem, o ganho de superfície representa área de 200m² para absorção de eletrólitos, água e nutrientes (MARTINS CAMPOS, 1993).

O processo de digestão e absorção dos nutrientes no ID envolve primeiramente processamento intraluminal, mediada por ácidos biliares e enzimas pancreáticas; fase epitelial, em que enzimas presentes na borda em escova dos enterócitos continuam o processo de hidrólise de carboidratos e proteínas; por fim a fase de transporte trans-epitelial, em que os eletrólitos, água e nutrientes alcançam o sistema linfático ou sangüíneo (GUYTON \& HALL, 1994). Qualquer distúrbio em uma dessas fases pode resultar em má-absorção de gorduras, vitaminas, proteínas, carboidratos, eletrólitos, minerais e água (CRAWFORD, 1999).

\subsection{DESNUTRIÇÃO E SÍNDROME DE MÁ-ABSORÇÃO}

Uma dieta adequada deve fornecer energia, oriunda de carboidratos, gorduras e proteínas; aminoácidos e ácidos graxos essenciais; vitaminas e minerais que possibilitem o crescimento, desenvolvimento e manutenção da vida. O estado nutricional é o resultado da interação entre o que se come, o estado de saúde e o ambiente onde se vive (WHO, 2004).

Má-nutrição é definida como o estado de estar mal nutrido e pode resultar do desequilíbrio entre as necessidades corpóreas e a ingestão de nutrientes (www.merck.com). Clinicamente, estar mal nutrido caracteriza-se por freqüentes infecções ou doenças relacionadas com a deficiência de proteína, energia e micronutrientes (WHO, 2000).

Má-nutrição primária se refere à deficiência de um ou de todos os macronutrientes ou micronutrientes. Enquanto, na má-nutrição secundária o suprimento de nutrientes está correto, porém a má-nutrição resulta da má-absorção dos nutrientes, estoque ou uso deficiente de 
nutrientes, excesso de perda ou aumento das necessidades de nutrientes (KANE \& KUMAR, 1999).

A má-nutrição protéico-calórica pode ser resultante da ingestão inadequada de macronutrientes, deficiência de energia ou de micronutrientes e está relacionada com várias síndromes clínicas (WORLD HEALTH ORGANIZATION, 1973). Os extremos dos quadros clínicos são marasmo e kwashiorkor.

Os métodos de avaliação nutricional empregados para detectar indivíduos mal nutridos devem incluir o peso e variação temporal do mesmo, medidas antropométricas e determinações hematológicas e séricas, como valores de albumina e transferrina (WAITZBERG \& FERRINI, 1997).

O marasmo é a resposta final da adaptação metabólica à extrema carência energética (XAVIER, 1999). O indivíduo marasmático apresenta perda importante da massa muscular, enfraquecimento e enrugamento da pele e, entre as conseqüências, imunodeficiência e anemia são as mais freqüentes (CHANDRA, 1981; KANE \& KUMAR, 1999). O kwashiorkor ocorre quando há significante deficiência protéica e relativo excesso de caloria. Essa situação não se restringe à deficiência primária da dieta, mas também em casos de diarréia crônica devido à má-absorção, enteropatias com perda de proteínas, síndrome nefrótico e queimaduras extensas (KANE \& KUMAR, 1999). Essa segunda forma de má-nutrição protéica-calórica é mais grave e está associada a hipoalbuminemia ocasionando anasarca e outras conseqüências. Podem ocorrer situações em que há combinação das duas formas de deficiência protéicacalórica (KANE \& KUMAR, 1999).

Alguns estudos experimentais utilizando dietas deficientes em proteína têm reproduzido quadro semelhante a marasmo e kwashiorkor em primatas não-humanos, sendo esses animais considerados como modelos para o estudo de má-nutrição (GEIST et al., 1972; RANA et al., 2001; SANDHYAMANI et al., 1999; WOLF, 1972). 
A má-nutrição pode piorar quadros de diarréia e/ou má-absorção em função da redução da secreção de enzimas pancreáticas e diminuição da atividade enzimática na borda em escova das células epiteliais da mucosa intestinal. Essas alterações podem ser observadas em humanos, assim como experimentalmente em primatas não-humanos (JUNIOR et al., 1997; RANA et al., 2001; SANDHYAMANI et al., 1999).

A síndrome de má-absorção é conseqüência da dificuldade na digestão ou absorção de nutrientes oriundos dos alimentos ingeridos. Geralmente, má-absorção pode resultar de vários processos mórbidos e seus sintomas principais são diarréia, dilatação intestinal por gases, fezes pastosas e graxentas, perda de massa muscular e distensão abdominal. O quadro clínico de má-absorção pode prejudicar o desenvolvimento corpóreo ou ocasionar doenças secundárias específicas relacionadas com má-nutrição (RILEY \& TURNBERG, 1993; TRIER, 1993).

Clinicamente, as síndromes de má-absorção têm sintomatologia semelhante, podendo decorrer, todavia, de causas diferentes. Assim, é fundamental o diagnóstico diferencial das várias causas desencadeantes do processo.

Nos animais, processos de má-absorção comumente ocorrem em conseqüência de doenças gastrintestinais que, geralmente, ocasionam perda de proteínas, diminuição do apetite, atraso no desenvolvimento, emagrecimento e caquexia, quando as necessidades nutricionais não são mantidas (BARKER \& DREUMEL, 1993).

Dentre as causas de má absorção, baseadas na fisiopatologia, devem ser considerados: 1- processo secundário a má-digestão; 2- lesão entérica caracterizada por redução da capacidade de absorção; 3- morte das células epiteliais; 4- alteração da drenagem linfática ou venosa; 5- distensão da lâmina própria por células (DUNCAN \& PRASSE, 1986).

A insuficiência pancreática é causa mais comum de má-digestão intraluminal nos animais domésticos e no homem, decorrente de atrofia ou fibrose pancreática (CRAWFORD, 
1999; BARKER \& DREUMEL, 1993). Enquanto, a deficiência de sais biliares é raramente relatada nos animais domésticos (BARKER \& DREUMEL, 1993). Na fase epitelial os processos caracterizados por atrofia de vilosidades são geralmente associados aos distúrbios de digestão e absorção dos nutrientes (BARKER \& DREUMEL, 1993).

O metabolismo de gorduras envolve as três fases da digestão e absorção. A ausência de lipase pancreática prejudica a lipólise e pode ser decorrente tanto dos processos de atrofia ou fibrose pancreática, como secundária a atrofia de vilosidades em que há falha na liberação de colecistoquinina. A formação de micelas pode estar reduzida pela diminuição dos sais biliares nos casos de colestase hepática, obstrução biliar ou lesão localizada no íleo. A redução da área de absorção intestinal, bem como da drenagem linfática poderão também contribuir para má-absorção de gorduras. A conseqüência clínica mais comum da máabsorção de gorduras é a esteatorréia e a menor assimilação de vitaminas lipossolúveis, cálcio e zinco (BURROWS et al., 1995).

A má-digestão de carboidratos poderá ocorrer em casos de redução da secreção de amilase pancreática; redução da superfície absortiva intestinal e em casos de enterócitos mal diferenciados ou imaturos, que exibem menor quantidade de oligossacaridases na borda em escova. O resultado da má-absorção de carboidratos é o aumento de fluido por osmose no ID e fermentação por bactérias no cólon (BARKER \& DREUMEL, 1993).

Quanto às proteínas, os mecanismos envolvidos na menor absorção estão relacionados com a redução da atividade proteolítica das enzimas pancreáticas, redução da área de absorção intestinal e menor digestão na fase epitelial. A atrofia da mucosa do duodeno pode resultar em menor secreção de enteroquinases, que são importantes para ativação do tripsinogênio pancreático em tripsina. Cães, bem como outros animais, com má-absorção na fase mucosal, podem apresentar concomitante insuficiência pancreática pela deficiência de enteroquinases (BARKER \& DREUMEL, 1993). 
Os demais nutrientes, como minerais e vitaminas, também apresentam a digestão e absorção prejudicada nos casos de redução da área de absorção.

O diagnóstico diferencial dentre as causas de má-absorção pré-entérica, entérica ou pós-entérica, necessita de exames clínico-laboratoriais, tais como: função pancreática exócrina, teste de absorção de D-xilose, hemograma completo, bioquímica sérica (proteínas totais, albumina e glicose sérica), coproparasitológico e coprocultura (DUNCAN \& PRASSE, 1986; RILEY \& TURNBERG, 1993; TRIER, 1993). Para o diagnóstico definitivo de casos de diarréia crônica não responsiva é necessária a realização de biópsia intestinal, seja por endoscopia ou laparotomia exploratória (TAMS, 2003).

Nos pacientes humanos, com suspeita de síndrome de má absorção, também, se pesquisa os anticorpos IgA anti-gliadina e IgA anti-endomísio de músculo liso e realiza-se biópsia intestinal, para descartar a doença celíaca (KAGNOFF, 1992; TRIER, 1993).

\subsection{ASPECTOS GERAIS DA IMUNOLOGIA E INFLAMAÇÃO DO TRATO INTESTINAL}

A mucosa intestinal é a interface entre os meios externo e interno e está sob constante estímulo decorrente da ingestão de antígenos estranhos, presença de microrganismos, de nutrientes e de drogas (DOE, 1989). Esses estímulos são fundamentais para o desenvolvimento e maturação do sistema imune sistêmico (METESCKY \& RUSSELL, 1998).

O tecido linfóide do trato gastrintestinal (GALT) é a chave da imunidade local e sistêmica, compreende $50 \%$ de todo o tecido linfóide do corpo e é o maior componente do tecido linfóide das mucosas (MALT) (ELWOOD \& GARDEN, 1999). 
O GALT compreende os folículos linfóides, as placas de Peyer, os linfonodos mesentéricos e o tecido linfóide não agregado formado pelos linfócitos da lâmina própria e intraepiteliais (ELWOOD \& GARDEN, 1999).

As células imunes do trato gastrintestinal formam população heterogênea de linfócitos T e B, plasmócitos, macrófagos, neutrófilos, eosinófilos, mastócitos, células dendríticas e um grande número de células apresentadoras de antígenos não profissionais (DOE, 1989; GERMAN et al., 1999). A adequada interação entre esses tipos celulares e os antígenos e nutrientes presentes no lúmen é essencial tanto para formação da resposta imune local, sistêmica e de outras mucosas, como para a tolerância ao grande número de estímulos antigênicos (GERMAN et al, 1999).

A perda da regulação da imunidade do trato gastrintestinal pode ocasionar infecções localizadas, sistêmicas e doenças auto-imunes (ELWOOD \& GARDEN, 1999). Dentre os padrões de disfunção intestinal incluem-se má-absorção, desordens de motilidade, translocação bacteriana e disfunção imune (THOMPSON, 1995).

Mecanismos inatos e adaptativos protegem o ambiente privilegiado da lâmina própria das alterações provocadas por antígenos estranhos. Dentre os primeiros, citam-se proteases digestivas secretadas e presentes na borda em escova do enterócito, a motilidade intestinal, a secreção de muco e a microflora residente. Quanto à resposta imune, essa pode ocorrer no lúmen intestinal, na superfície mucosa ou na lâmina própria (HOLMES \& LOBLEY, 1989; DOE, 1989).

O sistema imune gastrintestinal é compartimentalizado em sítio aferente ou indutor, onde ocorre o primeiro contato e estimulação das células imunes frente à exposição ao antígeno e sítio eferente ou efetor da resposta imune (ELWOOD \& GARDEN, 1999; PASCUAL et al., 1996). O sítio aferente é formado pelas placas de Peyer, folículos linfóides presentes na mucosa intestinal e linfonodos mesentéricos. Enquanto, o sítio eferente é 
formado pela lâmina própria do sistema gastrintestinal e os linfócitos intraepiteliais presentes na mucosa, e soma-se a esses as lâminas próprias dos sistemas respiratório e reprodutivo, e das glândulas salivares e mamárias, onde são encontrados linfócitos e demais células imunes (BRANDTZAEG et al., 1998; ELWOOD \& GARDEN, 1999; PASCUAL et al., 1996).

A comunicação entre os dois sítios da resposta imune do intestino ocorre pelos linfócitos T e B ativados. Essas células chegam a circulação sistêmica via linfáticos eferentes e o ducto torácico e, então, atingem a lâmina própria da mucosa dos demais órgãos que compõem o MALT. Nesses locais, esses linfócitos ficam retidos ou retornam ao intestino utilizando a expressão de moléculas de adesão na mucosa, como "addressin" (MAdCAM-1), e receptores de "homing", como L-selectina, na membrana de linfócitos migrantes (BRANDTZAEG et al., 1998; ELWOOD \& GARDEN, 1999; JAMES \& KIYONO, 1999).

Além, da circulação sistêmica, os linfócitos ativados também estimulam linfócitos $\mathrm{T}$ timo-independentes presentes na lâmina própria do intestino que mediariam a resposta efetora in situ (BRANDTZAEG et al., 1998; ELWOOD \& GARDEN, 1999). Acredita-se que os linfócitos migrantes ou extravasados permanecem nos vários microcompartimentos do GALT devido a expressão de quimocinas e móleculas de adesão aos componentes da matriz extracelular (BRANDTZAEG et al., 1998).

Nos sítios aferentes encontramos entre os enterócitos do epitélio superficial das placas de Peyer e folículos linfóides células especializadas denominadas células M; na região do domo, células apresentadoras de antígenos, que expressam complexo de histocompatibilidade (MHC) classe II; plasmócitos e linfócitos T CD4+ na região interfolicular, e linfócitos B nos centros germinativos (ELWOOD \& GARDEN, 1999). Soma-se a esses os enterócitos superficiais que participam ativamente da resposta imune, sintetizando e secretando quimocinas, citocinas e antígenos de MHC (BLAND, 1998; PERDUE, 1999). 
A lâmina própria do intestino é o maior sítio efetor e possui, em situações normais nos seres humanos, plasmócitos e linfócitos B (20 a 40\%); linfócitos T (40 a 60\%); macrófagos ( \pm $10 \%)$, eosinófilos ( \pm 5\%) e mastócitos ( $\pm 1-3 \%$ ) (PASCUAL et al., 1996). Nos cães como nos seres humanos, os plasmócitos são geralmente IgA+; há predomínio de linfócitos T-CD4+ na lâmina própria e predomínio de linfócitos T-CD8+ nas vilosidades (ELWOOD \& GARDEN, 1999; JAMES \& KIYONO, 1999).

Os linfócitos que compõem a lâmina própria e localizam-se entre os enterócitos são linfócitos que foram previamente ativados, migrando ou não para circulação sistêmica e retornando a mucosa intestinal, e são chamados células de memória (JAMES \& KIYONO, 1999). As células de memória, CD45RO+, são adaptadas a essa condição devida: 1- expressão de antígenos de superfície, que estão ausentes ou em baixo grau nas células virgens ("Naive cells", CD45RA+); 2- padrão de secreção de citocinas alterado; 3- capacidade funcional diferente e 4- resposta proliferativa frente a diferentes estímulos (JAMES \& KIYONO, 1999). As células $\mathrm{CD} 45 \mathrm{RO}+$ predominam na lâmina própria de seres humanos e de primatas nãohumanos (ELWOOD \& GARDEN, 1999; JAMES \& KIYONO, 1999).

A integridade da barreira intestinal é dependente da integração entre enterócitos, células imunes e citocinas, que irá determinar a ativação da resposta imune ou a supressão (PERDUE, 1999).

As citocinas são proteínas intercelulares solúveis produzidas por leucócitos que afetam o comportamento de outras células mediante a ligação a receptores de membrana específicos nas células alvo (JANEWAY et al., 1999).

As citocinas são denominadas linfocinas ou interleucinas (ILs) quando sintetizadas por linfócitos; interferons (IFNs) quando produzidas por leucócitos (IFN- $\alpha$ ), fibroblastos (IFN- $\beta$ ) e linfócitos T CD4+, linfócito T CD8+ e células T assassinas naturais (NK) (IFN- $\gamma)$; fator de 
necrose tumoral (TNF- $\alpha$ ) quando produzidas por macrófagos e células $\mathrm{T}$; e fator de transformação do crescimento (TGF- $\beta$ ) secretado por linfócitos T (JANEWAY et al., 1999).

$\mathrm{Na}$ mucosa intestinal as citocinas, incluindo ILs, IFNs e TNF- $\alpha$, afetam tanto os processos de homeostasia, como patológicos (ELWOOD \& GARDEN, 1999). Na lâmina própria do intestino, de seres humanos e primatas não-humanos, normalmente são encontrados linfócitos capazes de produzir IL-2, IL-4, IL-5 e IL-10 e IFN- $\gamma$ (JAMES et al., 1990; JAMES \& KIYONO, 1999). As células epiteliais também são capazes de sintetizar e secretar quimocinas e citocinas, tais como: IL-8 (quimocinas para leucócitos), TGF- $\beta$, TNF$\alpha$, entre outras (PERDUE, 1999). Por outro lado, os enterócitos são afetados pelas seguintes citocinas: IL-2, IL-1- $\beta$, IL-3, IL-4, IL-6, IL-13, IFN- $\gamma$, TNF- $\alpha$, TGF- $\beta$, TGF- $\beta 2$,e IGF (fator de crescimento semelhante a insulina) (PERDUE, 1999).

As alterações no padrão de citocinas produzidas na mucosa podem ser importantes na patogênese de doenças intestinais (JAMES \& KIYONO, 1999). O GALT apresenta a capacidade de responder aos antígenos intraluminais, sejam esses bactérias ou alimentos, excluindo, tolerando ou inflamando. A resposta resultante depende da interação entre os sistemas inato e imune intestinal e as características dos antígenos (ELWOOD \& GARDEN, 1999).

Nesse contexto, a chave para a resposta imune no GALT é a apresentação e processamento dos antígenos no intestino. Essa etapa pode ser realizada via células $\mathrm{M}$, o próprio enterócito e via células apresentadoras de antígeno auxiliares, dentre essas as células dendríticas que expressam CD68+, proteína S-100+ e outras (ELWOOD \& GARDEN, 1999; SARSFIELD et al., 1996).

No caso do antígeno ser apresentado via células epiteliais, na ausência de sinais coestimulatórios de moléculas presentes na superfície celular ou citocinas ou utilizando MHC 
não clássico via CD1b, ocorre a ativação de linfócitos T CD8+ e produção de TGF- $\beta$ com supressão da resposta inflamatória (STROBEL \& MOWAT, 1998).

A apresentação de antígeno via MHC classe II, presentes em enterócitos ou células M ou células dendríticas, na ausência de estímulos co-estimulatórios leva a ativação de linfócitos T CD4+ e produção de TGF- $\beta$, IL-4 e IL-10 (perfil TH3) ocasionando tolerância oral por supressão, anergia ou apoptose de clones de células T ativadas (GARSIDE \& MOWAT, 1997).

No entanto, se o antígeno for apresentado via MHC classe II, em um ambiente com perda da homeostasia da barreira intestinal, com presença de fatores co-estimulatórios, e conseqüentemente, com citocinas pró-inflamatórias, ocorrerá ativação de células T CD4+. Dependendo da natureza do estímulo, o padrão de secreção de interleucinas poderá mudar e, assim, com predomínio de IL-2, IFN- $\gamma$, TNF- $\alpha$ (citocinas pró-inflamatórias) resultará em resposta imune mediada por células, perfil TH1. Por outro lado, com o predomínio de IL-4, IL-5, IL-6, IL-9 e IL-10 há estímulo para produção de anticorpos IgA/ IgE e esse padrão de resposta é observada em parasitismo por helmintos e quadros de alergia (perfil TH2) (ELWOOD \& GARDEN, 1999).

Acrescenta-se que à ativação das células $\mathrm{T}$ segue-se, inicialmente, a expressão de receptores para IL-2 e a ligação de IL-2 a esses receptores é um dos eventos mais importantes para proliferação, diferenciação e funcionamento de células T (JAMES \& KIYONO, 1999). A IL-2, também, está envolvida na ativação de células $\mathrm{T}$ para síntese de imunoglobulinas responsáveis pela imunidade humoral (JAMES \& KIYONO, 1999).

A imunoglobulina A (IgA) predomina na mucosa e sua porção ativada (IgA-secretora) é liberada no lúmen intestinal, onde desempenha sua função de opsonização de antígenos bacterianos impedindo a adesão e invasão do enterócito. A IgA, também, desempenha importante papel na lâmina própria e atividade intracitoplasmática, onde participa da expulsão 
dos antígenos mediada por fagocitose e citotoxicidade mediada por anticorpo (MAZANEC et al., 1993).

O sistema imune é capaz de não responder a antígenos não patogênicos dada a interação entre seus vários componentes, como descrevemos anteriormente. O mecanismo envolvido nessa característica é específico e essencial para homeostasia do corpo. Tolerância oral é o termo usado para situações de ausência de resposta imune aos antígenos não patogênicos presentes no lúmen intestinal (PERDUE, 1999).

Geralmente, estabelece-se tolerância oral entre 5 a 7 dias e pode permanecer por vários meses na dependência de alguns fatores do próprio hospedeiro como do ambiente (ELWOOD \& GARDEN, 1999).

Quanto ao hospedeiro, citam-se os seguintes fatores idade, bagagem genética, grau de digestão intraluminal dos antígenos, efeito imunossupressor de lipopolissacarídeos bacterianos e a quantidade de antígeno absorvido na forma intacta pelos enterócitos (ELWOOD \& GARDEN, 1999). Quanto ao ambiente, consideram-se a natureza do antígeno, característica física do antígeno, ou seja, se é particulado ou solúvel e a dose antigênica relativa (ELWOOD \& GARDEN, 1999).

Os mecanismos envolvidos na tolerância oral podem ser divididos em modulação ativa ou inativação da resposta imune dos linfócitos. Esses processos podem ser mediados por citocinas supressoras da resposta inflamatória (TGF- $\beta$ ) ou indutoras de clones de células T anérgicas ou clones de deleção (apoptose) (ELWOOD \& GARDEN, 1999).

A identificação (imunofenotipagem) e quantificação (morfometria) da população celular da mucosa intestinal permitem estudos comparativos e, talvez, elucidativos das doenças inflamatórias do trato intestinal (GERMAN et al., 1999).

Acrescenta-se, ainda, que as alterações da mucosa intestinal podem variar em extensão e severidade, dependendo da resposta imune e do estímulo, isto explica a grande variação das 
manifestações clínicas encontradas em algumas patologias intestinais, como a doença celíaca (TRIER, 1993). Segundo KAGNOFF (1993), a evidência do mecanismo imune nas doenças inflamatórias intestinais é importante na patogênese da injúria tecidual desses processos.

O estudo de mecanismos imunes, em modelos animais, de processos humanos permite inferências sobre a patogenia e formas de controle de doenças de interesse médico. Como exemplo, cita-se a colite espontânea do sagüi-de-topete-branco que se assemelha à colite ulcerativa do homem (CLAPP et al., 1991; CLAPP, 1993). 


\section{MATERIAIS \& MÉTODOS}

\subsection{CASUÍSTICA}

\subsubsection{Animais}

Foram utilizados 57 calitriquídeos adultos, machos e fêmeas, procedentes do Criadouro Mucky e de outras instituições particulares regulamentadas pelo Instituto Brasileiro do Meio Ambiente e dos Recursos Naturais Renováveis (IBAMA). Os calitriquídeos usados pertenciam às espécies sagüi-de-tufo-preto (Callithrix penicillata), sagüis-de-tufo-branco (Callithrix jacchus), sagüi-de-cara-branca (Callithrix geoffroyi) e híbridos.

Os animais foram subdivididos em três grupos de estudo:

Grupo I: composto por 40 sagüis, 18 machos e 22 fêmeas, com sinais de SEP que foram acompanhados clínica e laboratorialmente.

Grupo II: formado por nove sagüis vivos e sadios, cinco machos e quatro fêmeas, cujos pesos e parâmetros clínicos estavam dentro da normalidade; não apresentavam parasitoses intestinais; mostravam dados laboratoriais relacionadas ao exame coprológico de fezes, função absortiva intestinal e exame de urina tipo I, dentro dos padrões habituais. Esse grupo foi usado para a avaliação coprológica das fezes e da função absortiva do intestino delgado.

Grupo III: constituído por oito sagüis, três machos e cinco fêmeas, que foram usados como controles para a avaliação histológica do jejuno. Esses animais foram selecionados a partir das seguintes características: 1causa de morte não relacionada com enteropatia; 2- o intestino delgado dentro dos parâmetros de normalidade, e 3- trato gastrintestinal sem autólise.

A distribuição dos sagüis, segundo espécie, sexo, idade, local de nascimento e peso, para cada grupo está apresentada na tabela 2. 
Tabela 2 - Distribuição dos sagüis por grupo, segundo espécie, sexo, idade, local de nascimento, tempo de cativeiro no Criadouro Mucky e peso

\begin{tabular}{|c|c|c|c|c|c|c|c|}
\hline CASO & GRUPO & ESPÉCIE ${ }^{1}$ & SEXO ${ }^{2}$ & $\begin{array}{l}\text { IDADE } \\
\text { (meses) }\end{array}$ & $\begin{array}{c}\text { LOCAL } \\
\text { NASCIMENTO }\end{array}$ & $\begin{array}{l}\text { Tempo de } \\
\text { cativeiro }\end{array}$ & $\begin{array}{c}\text { PESO } \\
\text { (gramas) }\end{array}$ \\
\hline 1 & I & Híbrido & $M$ & 78 & Mucky & 78 & 336 \\
\hline 2 & I & STP & $\mathrm{F}$ & 36 & Indeterminado & 8 & 270 \\
\hline 3 & I & STB & $\mathrm{F}$ & 60 & Indeterminado & 54 & 228 \\
\hline 4 & I & STB & $\mathrm{F}$ & 64 & Mucky & 64 & 362 \\
\hline 5 & I & Híbrido & $\mathrm{F}$ & 75 & Mucky & 75 & 300 \\
\hline 6 & I & Híbrido & $\mathrm{F}$ & 54 & Mucky & 54 & 290 \\
\hline 7 & I & STP & $M$ & 18 & Indeterminado & 18 & 204 \\
\hline 8 & I & STP & $\mathrm{F}$ & 66 & Indeterminado & 16 & 288 \\
\hline 9 & I & STP & $M$ & 36 & Indeterminado & 36 & 317 \\
\hline 10 & I & STP & $\mathrm{F}$ & 73 & Mucky & 73 & 237 \\
\hline 11 & I & Híbrido & $M$ & 55 & Mucky & 55 & 226 \\
\hline 12 & I & STP & $\mathrm{F}$ & 36 & Indeterminado & 35 & 150 \\
\hline 13 & I & STP & M & 90 & Mucky & 90 & 234 \\
\hline 14 & I & Híbrido & $M$ & 56 & Mucky & 56 & 242 \\
\hline 15 & I & STP & $M$ & 92 & Indeterminado & 92 & 217 \\
\hline 16 & I & STP & $M$ & 78 & Mucky & 78 & 265 \\
\hline 17 & I & Híbrido & $\mathrm{F}$ & 48 & Mucky & 48 & 325 \\
\hline 18 & I & STB & $\mathrm{F}$ & 58 & Mucky & 58 & 220 \\
\hline 19 & I & STP & $\mathrm{F}$ & 50 & Mucky & 50 & 267 \\
\hline 20 & I & STB & $\mathrm{F}$ & 43 & Indeterminado & 37 & 234 \\
\hline 21 & I & SCB & $\mathrm{F}$ & 72 & cativeiro & 17 & 270 \\
\hline 22 & I & SCB & $\mathrm{F}$ & 16 & Mucky & 16 & 217 \\
\hline 23 & I & Híbrido & $\mathrm{F}$ & 65 & Mucky & 65 & 279 \\
\hline 24 & I & STP & $\mathrm{F}$ & 60 & Mucky & 60 & 220 \\
\hline 25 & I & STP & $\mathrm{F}$ & 59 & Indeterminado & 59 & 266 \\
\hline 26 & I & STP & $M$ & 36 & Indeterminado & 28 & 199 \\
\hline 27 & I & SCB & $M$ & 36 & cativeiro & 17 & 309 \\
\hline 28 & I & STB & M & 96 & Indeterminado & 7 & 314 \\
\hline 29 & I & Híbrido & $M$ & 35 & Mucky & 35 & 399 \\
\hline 30 & I & Híbrido & $\mathrm{F}$ & 30 & Indeterminado & 11 & 287 \\
\hline 31 & I & STB & $M$ & 96 & Mucky & 96 & 282 \\
\hline 32 & I & Híbrido & $M$ & 64 & Mucky & 64 & 380 \\
\hline 33 & I & STP & $\mathrm{M}$ & 68 & Mucky & 68 & 295 \\
\hline 34 & I & Híbrido & $M$ & 16 & Mucky & 16 & 292 \\
\hline 35 & I & Híbrido & $\mathrm{F}$ & 48 & Mucky & 48 & 300 \\
\hline 36 & I & STP & $M$ & 78 & Mucky & 78 & 279 \\
\hline 37 & I & Híbrido & $M$ & 48 & Mucky & 48 & 331 \\
\hline 38 & I & Híbrido & $\mathrm{F}$ & 78 & Mucky & 78 & 328 \\
\hline 39 & I & STP & $\mathrm{F}$ & 48 & Mucky & 48 & 261 \\
\hline 40 & I & Híbrido & $\mathrm{F}$ & 42 & Mucky & 42 & 297 \\
\hline 41 & II & STP & M & 16 & Mucky & 16 & 353 \\
\hline 42 & II & SCB & $M$ & 120 & Indeterminado & - & 401 \\
\hline 43 & II & Híbrido & $M$ & 43 & Mucky & 43 & 497 \\
\hline 44 & II & STP & $M$ & 65 & Mucky & 65 & 352 \\
\hline 45 & II & STP & $M$ & 65 & Mucky & 65 & 294 \\
\hline 46 & II & STP & $\mathrm{F}$ & 30 & Indeterminado & - & 331 \\
\hline 47 & II & Híbrido & $\mathrm{F}$ & 60 & Mucky & 60 & 329 \\
\hline 48 & II & Híbrido & $\mathrm{F}$ & 72 & Mucky & 72 & 350 \\
\hline 49 & II & Híbrido & $\mathrm{F}$ & 47 & Mucky & 47 & 333 \\
\hline 50 & III & STB & $\mathrm{F}$ & 120 & Indeterminado & - & - \\
\hline 51 & III & STP & $\mathrm{F}$ & 36 & cativeiro & - & - \\
\hline 52 & III & STB & M & 20 & Indeterminado & - & - \\
\hline 53 & III & STB & $F$ & 28 & Indeterminado & - & - \\
\hline 54 & III & STP & $\mathrm{F}$ & 60 & Indeterminado & - & - \\
\hline 55 & III & STP & M & 35 & Mucky & - & - \\
\hline 56 & III & Híbrido & $\mathrm{F}$ & 24 & Indeterminado & - & - \\
\hline 57 & III & Híbrido & M & 24 & Indeterminado & - & - \\
\hline
\end{tabular}

${ }^{1} \mathrm{STB}=$ sagüi-de-tufo-branco, $\mathrm{STP}=$ sagüi-de-tufo-preto, $\mathrm{SCB}=$ sagüi-de-cara-branca. ${ }^{2} \mathrm{M}=$ macho. $\mathrm{F}=$ fêmea. 


\subsubsection{Alterações definidoras de SEP}

Como definido na literatura o quadro clínico de SEP apresentou as seguintes alterações: perda de peso progressiva e diarréia intermitente (CHALIAFOUX et al, 1982; CHALIAFOUX \& KING, 1993; MORIN, 1983; SAINSBURY et al, 1987).

\subsubsection{Critérios de inclusão e exclusão}

Os critérios de inclusão dos sagüis com SEP se basearam em: 1- sagüis nascidos em cativeiro ou que estiveram no criatório Mucky há mais de seis meses; 2- sagüis com peso abaixo do usual ou que apresentaram emagrecimento progressivo e 3- sagüis com diarréia intermitente.

Os critérios de exclusão dos casos clínicos foram: 1- animais que não apresentaram sinais de emagrecimento; 2- animais sem diarréia; 3- animais com infecção por Giardia sp; 4animais com outra doença que ocasionasse emagrecimento ou diarréia.

\subsection{O CRIADOURO MUCKY}

O Criadouro Mucky existe como projeto de proteção aos pequenos primatas há aproximadamente 20 anos, sob a coordenação de Lívia Botár. De 1985 a 1995, a sede se localizava na cidade de São Paulo, representando o início do projeto com 57 animais. Passou a ser considerada instituição em 1993. Do início de 1996 a abril de 1997, permaneceu em Campinas aonde chegou a albergar 101 sagüis. Foi transferido para Jundiaí, em abril de 1997. Neste mesmo ano, se tornou uma Organização não Governamental (ONG). Foi legalizado como criatório conservacionista e órgão de utilidade pública junto ao IBAMA em 1998 (RG 1/35/1998/000193-9). Em novembro de 2000, o criatório passou a ter sede própria, com área 
de $8.100 \mathrm{~m}^{2}$ localizado no Bairro de Medeiros, em Jundiaí. Possui área construída de $700 \mathrm{~m}^{2}$, formada pela sede central, alojamentos para funcionários, cozinhas (para os funcionários e em separado para os animais), banheiros, garagem, viveiros (externos ou em blocos) e enfermaria.

Dentre os objetivos do criatório citam-se proteção e o bem estar de sagüis mantidos em cativeiro. $\mathrm{Na}$ época do presente estudo possuía cerca de 10 funcionários, trabalhando em período integral direta ou indiretamente com os animais, além, de eventuais voluntários.

Ao final do ano 2000, mantinha 185 sagüis, com 100 machos e 85 fêmeas e a maioria com idade superior a 18 meses. O criatório possuía seis espécies de calitriquídeos e uma espécie de cebídeo. O número de indivíduos por espécies podia ser dividido em 45 sagüis pertencentes à espécie sagüi-de-tufo-branco; 52, sagüi-de-tufo-preto, cinco, sagüi-de-carabranca, dois, sagüi-leãozinho (Callitrhix pygmae), um sagüi-de-weid (Callithrix kuhlii), 79 calitriquídeos híbridos e um exemplar de cebídeo pertencente à espécie mico-de-cheiro (Saimiri sciureus).

Todos os animais apresentavam registro, constituído por um nome e um número, mas rotineiramente as marcas particulares como presença de cicatriz e distribuição de áreas brancas, individualizavam os sagüis. Cada animal possuía uma ficha de anotações dos pesos mensais e observações clínicas.

O criatório apresentava em torno de 50 viveiros, sendo alguns externos e isolados e outros dispostos em blocos. Os viveiros eram telados nas laterais, apresentavam a base de alvenaria revestida por cimento e eram cobertos por telhas de amianto ou de cerâmica (Figura 1 e 2). Nestes recintos, existia área de cambeamento medindo $45 \times 60$ x $60 \mathrm{~cm}$ que era delimitada por gaiola de ferro, onde se colocavam os pratos de alimento, de água e a caixa de madeira para ninho (Figura 3). 
A limpeza dos viveiros era realizada diariamente quando as fezes eram raspadas manualmente e depois varridas e recolhidas. A cada dois dias, os viveiros eram lavados com água sob pressão, sabão em pó e solução de cloro. Os galhos, que ornamentavam cada viveiro e os ninhos de madeira eram trocados e lavados periodicamente, sem intervalo pré-definido. Os panos que revestem o interior dos ninhos eram trocados e lavados pelo menos uma vez por semana.

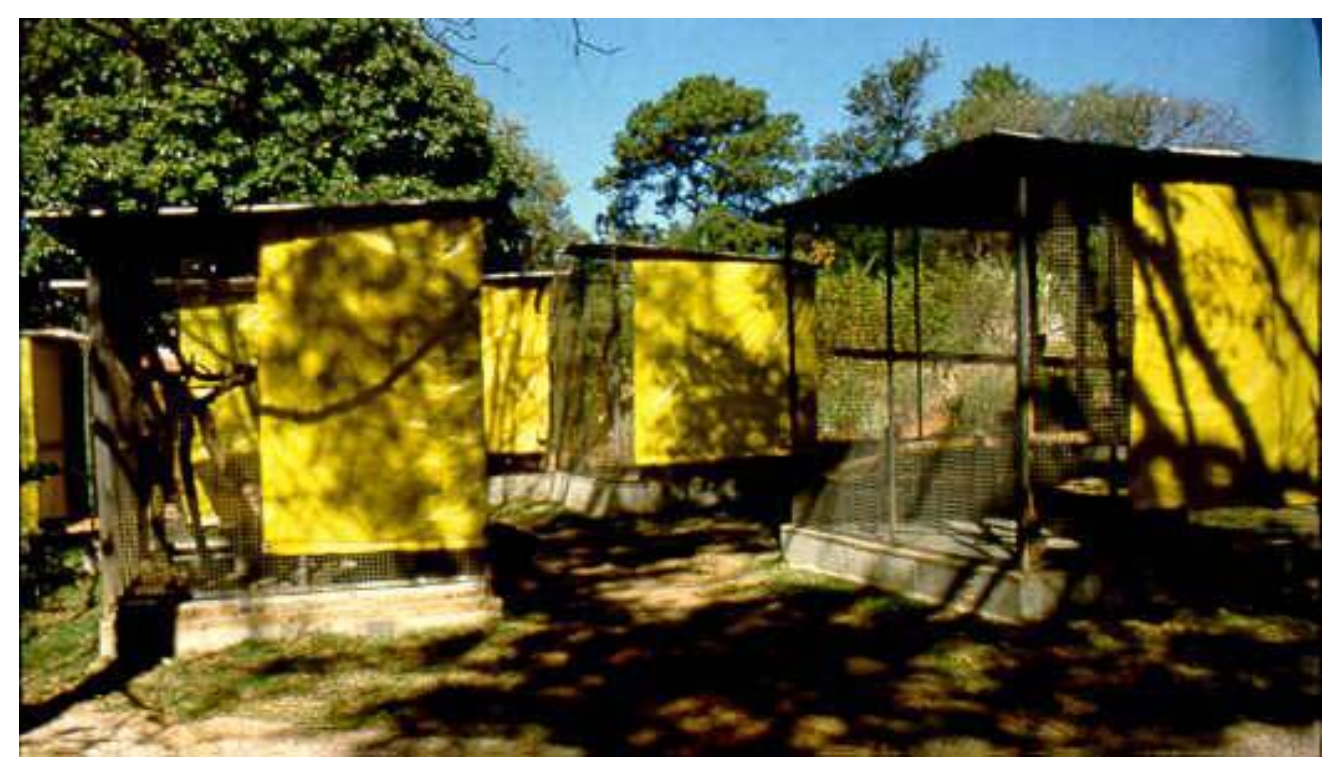

Figura 1 - Criadouro Mucky, vista lateral dos viveiros externos isolados. 


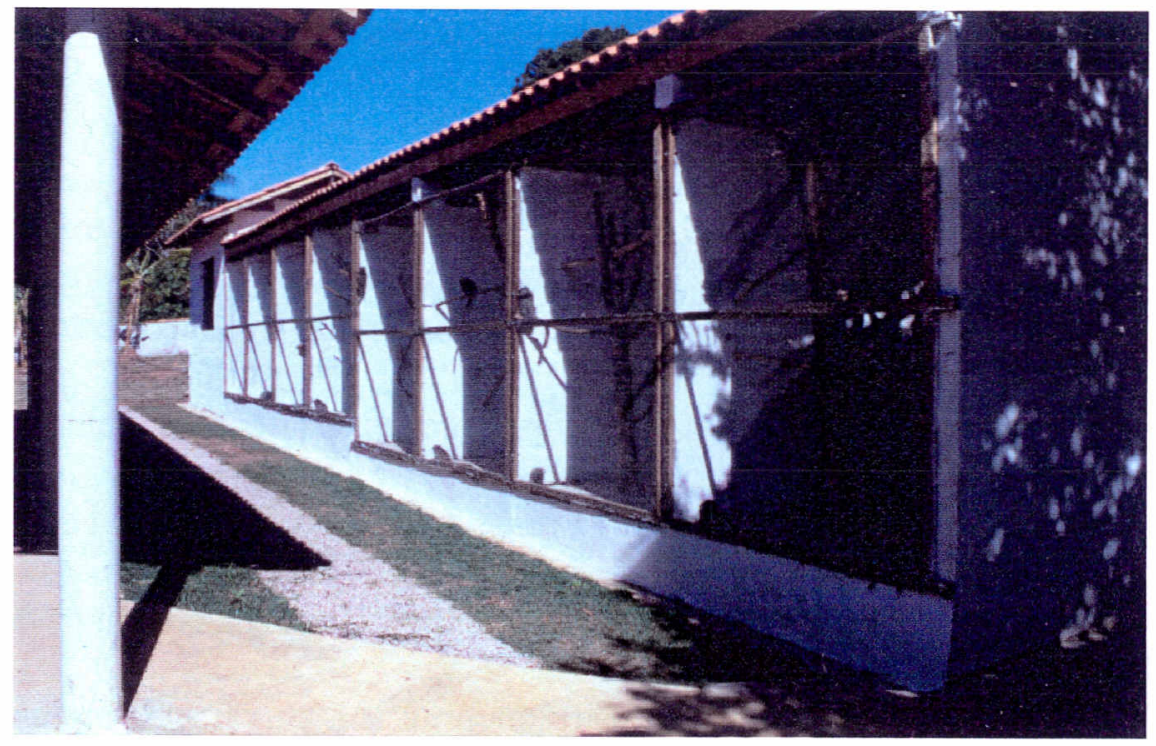

Figura 2 - Criadouro Mucky, vista lateral dos viveiros justapostos em blocos.

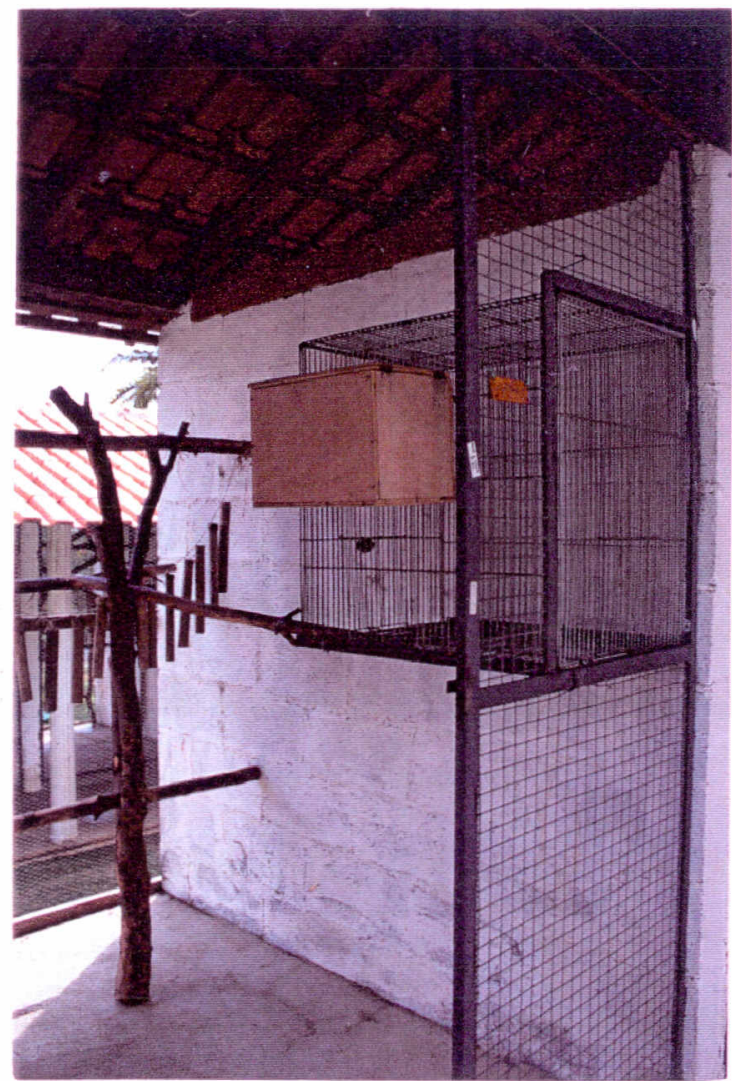

Figura 3- Criadouro Mucky, vista lateral da área de cambeamento de um viveiro. 


\subsection{DIETA OFERECIDA NO CRIADOURO MUCKY}

Os alimentos que compunham a dieta dos sagüis eram obtidos junto ao Sacolão de Jundiaí e ao Centro de Abastecimento de Campinas (CEASA - Campinas). As frutas e legumes eram doados semanalmente, enquanto os frangos, os litros de leite de vaca longavida ou as latas de leite-em-pó e os ovos eram comprados semanalmente ou quinzenalmente. A água oferecida para beber era proveniente de poços artesianos e a mesma era fervida e mantida tampada até ser servida aos animais, pela manhã do dia seguinte. Os alimentos e a água eram oferecidos ad libtum. Os recipientes de louça para os alimentos eram retirados e lavados com água e sabão neutro no intervalo entre cada refeição. Ao final da tarde todos os recipientes para alimentos e água eram removidos e lavados para a utilização no próximo dia.

A dieta rotineiramente utilizada pelo Criadouro Mucky, no ano de 2000, apresentava cerca de 45 itens diferentes. Esses eram ofertados aleatoriamente conforme a disponibilidade semanal ou mensal.

Distribuição dos itens por refeição, período do ano e horário:

$1^{\circ}$ Semestre (janeiro a junho)

$1^{\text {a }}$ Refeição "láctea" / 07:00 hs - leite de vaca, iogurte, leite fermentado $\left(\right.$ Chamyto $\left.^{\circledR}\right)$, pão-francês amanhecido, Farinha-láctea ${ }^{\circledR}$, Sustagem ${ }^{\circledR}$, pão-demel sem chocolate, mel, bolacha-de-maisena.

$2^{\text {a }}$ Refeição legumes/ proteína / 11:30 hs - batata, cenoura, abobrinha, abóbora, tomate, mandioquinha, mandioca, couve-flor, batata-doce, beterraba, berinjela, cará, quiabo, milho, vagem, chuchu, polenta-de-fubá, macarrão, ração comercial para cães, carne de frango, ovos e ossos de frango.

$3^{\mathrm{a}}$ Refeição frutas / 15:00 hs - mamão, banana, maçã, uva, manga, goiaba, laranja, melancia, abacaxi, melão, morango, pêra, ameixa, mexerica, jabuticaba, tangerina e maracujá. 
$2^{\circ}$ Semestre (julho a dezembro) - inversão da ordem das refeições

$1^{\text {a }}$ Refeição legumes/ proteínas / 7:00 hs - mesmos itens.

$2^{\mathrm{a}}$ Refeição frutas / 11:30 hs - mesmos itens.

3ª Refeição "láctea" / 15:00 hs - mesmos itens.

As quantidades de alimentos usados em cada refeição e preparados para os 185 animais, bem como a forma de processamento e apresentação de cada, foram apresentadas na tabela 3.

A freqüência dos itens ofertados, por mês, durante um ano foi levantada a partir das anotações diárias da composição de cada refeição utilizada. 
Tabela 3 - Itens alimentares utilizados na dieta dos 185 sagüis do Criadouro Mucky no ano de 2000, segundo o processamento, forma de apresentação e quantidades usadas por refeição

\begin{tabular}{|c|c|c|c|}
\hline ALIMENTO & QUANTIDADE $^{1}$ & PROCESSAMENTO & APRESENTAÇÃO \\
\hline Ovo & $2 \mathrm{dz}$ & Cozido & Cortado em pedaços \\
\hline Frango & 2,0 a $2,5 \mathrm{Kg}$ & Cozido & Desossado, desfiado/ bolinho \\
\hline Leite e derivados & 10 a $12 \mathrm{~L}$ & Fervido & Mingau de maisena ralo \\
\hline Batata s/ casca & 4 a $5 \mathrm{Kg}$ & Cozida & Cortado em pedaços \\
\hline Abobrinha & 2,5 a $3,0 \mathrm{Kg}$ & Cozida & Cortado em pedaços \\
\hline Mandioquinha & $2 \mathrm{Kg}$ & Cozida & Cortada em pedaços \\
\hline Chuchu & $3 \mathrm{Kg}$ & Cozido & Cortada em pedaços \\
\hline Macarrão & 3 pcte. parafuso $/ 500 \mathrm{~g}$ & Cozido & Inteiro \\
\hline Polenta & $2 \mathrm{Kg}$ fubá/ 5L água & Cozida & Cortada em pedaços \\
\hline Pão-de-mel sem chocolate & 1 pcte/ 10L leite & - & Cortada em pedaços \\
\hline Farinha Láctea ${ }^{\circledR}$ & 1 lata/ 10L leite & - & Misturado ao leite \\
\hline Sustagem $^{\circledR}$ & $1 / 2$ lata/ $10 \mathrm{~L}$ leite & - & Misturado ao leite \\
\hline Pão-francês & 5-8 pães/ 10L leite & - & Cortado e misturado ao leite \\
\hline Banana & $3 \mathrm{a} 4 \mathrm{dz} /$ nanica & In natura & Com ou sem casca e cortada \\
\hline Maçã & $3 \mathrm{Kg}$ & Lavada e in natura & Cortada em pedaços \\
\hline Uva & $10 \mathrm{Kg}$ & Lavada & Cortada \\
\hline Mamão & 2 a 3 unidades & In natura & Cortado em pedaços \\
\hline Manga & 4-6 un. /10L suco & Batida como suco & Misturado ao leite \\
\hline Goiaba & $2 \mathrm{dz}$ & Lavada e sem semente & Cortada em pedaços \\
\hline Mexerica & $3-4 \mathrm{dz}$ & Retirada a casca & Cortada \\
\hline
\end{tabular}

${ }^{1} \mathrm{dz} .=$ dúzia, pcte. $=$ pacote, un. $=$ unidade

\subsubsection{Avaliação da composição nutricional da dieta oferecida}

Procedeu-se, em separado, uma avaliação do consumo e composição nutricional da dieta oferecida e consumida buscando estimar a ingestão real de nutrientes pelos sagüis do Criadouro Mucky. Para tanto foi formulada uma dieta padrão que representasse a alimentação normalmente utilizada no criatório.

Foram utilizados 10 sagüis adultos de ambos os sexos e pertencentes às espécies sagüi-de-tufo-preto, sagüi-de-cara-branca e sagüis híbridos. O critério de seleção dos animais 
foi clínico. Assim, os animais controles, dois machos e três fêmeas apresentavam fezes firmes e formadas e peso dentro do padrão da espécie. Os sagüis doentes com sinais de SEP, dois machos e três fêmeas apresentavam fezes pastosas a diarréicas intermitentes e peso abaixo do usual.

Os animais foram alojados em gaiolas de ferro individuais, medindo $45 \times 60 \times 60 \mathrm{~cm}$ com fundo de grade. Cada gaiola foi ornamentada com um galho transversal, que dificultava a possibilidade do animal defecar ou urinar sobre o prato de alimentação, e com um ninho de madeira forrado internamente com pano, como áreas de descanso. As gaiolas foram colocadas sobre bandeja plástica de forma a permitir a coleta total dos restos de alimento e o local do experimento foi forrado com plástico preto de maneira a ter contraste entre os alimentos e o chão.

A dieta padronizada para o experimento foi elaborada e oferecida da seguinte forma:

$1^{a}$ Refeição/ 07:30 hs - bolinho de frango cozido com batata e cenoura cozidas e farinha de milho. Foram utilizadas $850 \mathrm{~g}$ de carne de frango cozida e desossadas; $600 \mathrm{~g}$ de batata cozida e descascada; $574 \mathrm{~g}$ de cenoura raspada e cozida e $300 \mathrm{~g}$ de farinha-de-milho. Esses bolinhos foram preparados cinco dias antes do início do experimento, mantidos congelados e diariamente aquecidos no forno convencional à $180^{\circ} \mathrm{C}$ por 15 minutos antes de serem fornecidos aos animais. Foram distribuídos quatro bolinhos/ sagüi/ dia.

$2^{\mathrm{a}}$ Refeição/ 12:30 hs - bananas nanicas e maçãs cortadas em pedaços.

$3^{\mathrm{a}}$ Refeição/ 16:30 hs - bananas nanicas descascadas e amassadas com Farinha Láctea ${ }^{\circledR}$ ( 1 colher das de café rasa de farinha-láctea/ sagüi).

Os sagüis foram transferidos para o local de experimentação cinco dias antes do início do experimento. 
O consumo de alimento foi determinado por 10 dias consecutivos, usando balança de precisão com sensibilidade para 0,01g (Balança modelo AS 2000, Martes).

O procedimento para determinação do consumo constituiu, inicialmente, da pesagem de cada item alimentar em separado e, ao final do período de cada refeição, pesagem das sobras em separado, que foram recolhidas com auxílio de pinça anatômica. Para corrigir, diariamente, a perda de peso decorrente da evaporação da água das frutas e dos alimentos cozidos, um recipiente com alimentação referente a cada refeição foi colocado ao lado das gaiolas para cálculo da porcentagem de evaporação.

O consumo de alimentos foi calculado pela fórmula:

$$
\begin{aligned}
& \% \text { evaporação }=[(\text { peso final } x \text { 100) } / \text { peso inicial }]-100 \\
& \text { Alimento consumido = alimento oferecido - (alimento recusado }+\% \text { evaporação })
\end{aligned}
$$

Diariamente, amostras significativas de cada alimento oferecido foram recolhidas, acondicionadas em recipientes herméticos de plástico e armazenadas no freezer. Essas amostras constituíram o pool de alimentos representativo de todo período experimental.

O preparo dos alimentos para análise bromatológica constituiu no descongelamento das amostras, homogeneização das mesmas, secagem em estufa à $65^{\circ} \mathrm{C}$, moagem em moinho com peneira de $1 \mathrm{~mm}$ e envio ao laboratório para análise.

As amostras foram analisadas no Laboratório de Nutrição Animal da Faculdade de Ciências Agrárias e Veterinárias - Campus de Jaboticabal, Universidade Paulista Júlio de Mesquita (UNESP-Jaboticabal), segundo os protocolos descritos na A O A C - Association of the Official Ananlitical Chemists (1995). Nos alimentos foram determinadas a MS, PB, EE, FB e MM. Os ENN foram calculados a partir da determinação dos demais nutrientes incluindo a água e a soma foi subtraída de 100, ou seja, usando o seguinte cálculo [100- 
(água+PB+EE+MM+FB)]. A média de energia metabolizável foi estimada a partir das concentrações de energia na proteína, gorduras e carboidratos utilizando os fatores de conversão 4, 9 e $4 \mathrm{Kcal} / \mathrm{g}$, respectivamente (NRC 2003). As análises foram conduzidas em duplicata, sendo repetidas quando variaram mais do que $5 \%$.

Assim, o consumo médio das três refeições foi calculado pela fórmula:

$$
\text { Consumo médio }(\%)=\frac{\text { Consumo alimento }}{\text { Consumo total de MS }} \times 100
$$

A composição nutricional da dieta consumida pelos sagüis no criadouro Mucky foi determinada utilizando programa de computador para balanceamentos de rações (UFFDA Animal Nutrition), cujo cálculo foi realizado a partir dos resultados de consumo médio obtidos durante o período experimental e dos resultados da composição química dos alimentos determinada laboratorialmente (CARCIOFI, 1996).

A análise dos dados baseou-se na comparação desses resultados com os preconizados no Nutrient Requirements of nonhuman primates (NRC, 2003).

\subsubsection{Avaliação quantitativa da eficiência digestiva}

Para a avaliação quantitativa da eficiência digestiva foram comparados os coeficientes de digestibilidade aparente da MS, PB, EE, ENN, MM e FB de uma mesma dieta padronizada e consumida por animais controles e por animais com sinais de SEP em um único período. 
Foram utilizados os sagüis do item anterior com exame coproparasitológico negativo. O alojamento, local do experimento e a dieta padronizada foram os mesmo do item 4.3.1.

O ensaio de digestibilidade foi baseado no método Clássico ou Convencional de coleta total (CARCIOFI, 1996; SIBBALD 1982). Os animais foram alimentados com uma dieta de composição conhecida e foram realizados balanços entre o que foi ingerido e o que foi eliminado, a partir da coleta total das excretas, sendo que a diferença corresponde aos nutrientes efetivamente digeridos e absorvidos. O protocolo foi dividido em período preliminar ou de adaptação e período de coleta.

\subsubsection{Período Preliminar}

Esta etapa consistiu na quantificação da ingestão de alimentos de cada sagüi e avaliação da adaptação desses à dieta padronizada e oferecida. Como a dieta foi padronizada conforme a rotineiramente utilizada pelo criatório não foi necessária à adaptação dos sagüis a mesma. O consumo de alimento foi determinado por cinco dias consecutivos (dias 1 a 5) e os procedimentos e cálculos foram similares aos descritos no item 4.3.1.

\subsubsection{Período de coleta de fezes}

Durante esse período, além dos procedimentos anteriores, foi realizada a coleta de excretas durante cinco dias consecutivos (dias 6 a 10). Essas fezes foram recolhidas após terem sido retirados, com auxílio de pinça anatômica, os restos de alimentos e pelos aderidos. Foram acondicionadas em recipientes apropriados de plástico e congeladas em freezer.

\subsubsection{Análise Bromatológica}

O preparo das amostras de alimentos e das fezes totais para essa análise seguiu os passos descritos no item 4.3.1. 
4.3.2.4. Cálculo do coeficiente de digestibilidade aparente

O coeficiente de digestibilidade aparente (D.A.), da MS, PB, MM, FB, EE e ENN foi calculado segundo POND et al. (1995), usando a fórmula:

$$
\text { D.A. }(\%)=\frac{\left(\begin{array}{c}
\text { Nutriente } \\
\text { Ingerido }
\end{array}\right)-\left(\begin{array}{c}
\text { Nutriente } \\
\text { nas Fezes }
\end{array}\right)}{\text { Nutriente Ingerido }} \times 100
$$

Os coeficientes calculados para os controles e para os sagüis com sinais de SEP foram comparados.

\subsection{ACOMPANHAMENTO CLÍNICO}

Os sagüis acompanhados clinicamente foram examinados fisicamente uma a duas vezes por semana na enfermaria do Criadouro Mucky. Os dados observados foram anotados em fichas clínicas individualizadas.

Os animais com sinais de SEP e controles sadios foram, inicialmente, colocados em gaiolas de pesagem medindo $35 \times 23 \times 35 \mathrm{~cm}$, pesados em balança eletrônica com precisão de $0,1 \mathrm{~g}$ e, contidos fisicamente para realização do exame físico.

Os parâmetros clínicos avaliados foram: peso (gramas), temperatura, exame de mucosas aparentes, hidratação baseada no turgor cutâneo, palpação abdominal, exame dos linfonodos periféricos, auscultação cardio-torácica, qualidade do pelame, capacidade de agarrar com as patas e avaliação da marcha. 
Os animais doentes quando apresentavam diarréia foram medicados com:

1. antibióticos - eritromicina, suspensão oral na dose $50 \mathrm{mg} / \mathrm{Kg}$, a cada 12 horas durante 7 a 10 dias, ou ciprofloxacina xarope $50 \mathrm{mg} / \mathrm{ml}$, na dose $20 \mathrm{mg} / \mathrm{Kg}$, a cada 12 horas durante 7 a 10 dias, ou metronidazol suspensão (Flagyl ${ }^{\circledR} 4 \%$ pediátrico, Laboratórios Roche) na dose $25 \mathrm{mg} / \mathrm{Kg}$ a cada 12 horas durante 7 a 10 dias, ou enrofloxacina 2,5\%, na dose $5 \mathrm{mg} / \mathrm{Kg}$, diluído em 1,0 $\mathrm{ml}$ de solução fisiológica, a cada 24 horas, via subcutânea durante 5 dias.

2. fluidoterapia via subcutânea com solução de Ringer Lactato/ 3-5 ml/ a cada 8 horas ou 12 horas, durante 7 dias ou mais.

3. solução pediátrica de aminoácidos (Aminoped ${ }^{\circledR} 10 \%$, Laboratório Fresenius) na dose $0,2 \mathrm{ml} /$ sagüi via subcutânea, a cada 24 horas durante 7 dias ou mais.

4. vitamina do complexo B injetável na dose $0,4 \mathrm{ml} /$ sagüi, via subcutânea, a cada 24 horas durante 7 dias ou mais.

Quando no período de diarréia, a dieta desses animais foi alterada com substituição do leite de vaca e seus derivados e do ovo cozido por leite de soja ou por suco de frutas e mantidos com soro caseiro, ao invés de água fervida.

Os animais com mucosas hipocoradas foram medicados com suspensão oral de complexos vitamínicos pediátricos a base de sulfato ferroso (dose de 0,4 $\mathrm{ml}$ / sagüi, a cada 24 horas, Combiron ${ }^{\circledR}$ líquido, Laboratório Aché), ácido fólico (dose de 0,2 ml/ sagüi, a cada 24 horas, Endofolin ${ }^{\circledR}$, Laboratório Larjan Indústria e Comércio Ltda) vitaminas do complexo B (dose de 0,2 a 0,4 ml/ sagüi, a cada 24 horas, Laboratório Roche) e vitamina C (dose de 3 gotas/ sagüi, a cada 24 horas, Cewin ${ }^{\circledR}$ Laboratório Roche).

$\mathrm{Na}$ vigência da diarréia os animais foram colocados em gaiolas isoladas com a finalidade de evitar possíveis contaminações para os contactantes do cativeiro e para que tivessem um acompanhamento clínico particularizado. 


\subsection{EXAMES LABORATORIAIS}

\subsubsection{Coleta de fezes e urina}

Os procedimentos de coleta de amostras biológicas foram realizados nas dependências do Criadouro Mucky.

As amostras de fezes e urina (exame de urina Tipo I) foram colhidas de sagüis, controles e sagüis com sinais de SEP, a cada 30 dias utilizando gaiolas individuais de ferro medindo 45 x 30 × $45 \mathrm{~cm}$, bandejas de plástico colocadas embaixo dessas gaiolas, seringas de $5 \mathrm{ml}$ com agulhas $25 \times 7 \mathrm{G}$ e espátulas de madeira (Figura 4). As coletas foram realizadas com os animais em jejum, assim que amanhecia. As amostras de fezes eram armazenadas em recipientes plásticos com tampas (frascos de filme fotográfico) e a urina em seringas de $5 \mathrm{ml}$, sendo utilizadas quantas fossem necessárias para coleta total das excretas. As mesmas eram mantidas sob refrigeração até o momento do processamento laboratorial.

A coleta de urina para avaliação da função absortiva do intestino delgado utilizou sistema de coleta elaborado para essa função e que foi composto por funil com anteparo lateral, tela de alumínio para separação das fezes e suporte de ferro para apoiar o sistema de coleta (Figura 5). O material utilizado para construção do sistema de coleta foi chapa galvanizada número 26 , com $0,50 \mathrm{~mm}$ de espessura, para o funil e anteparo lateral, que mediam 50 × $36 \mathrm{~cm}$ com saída 0,5 ” e 42 × 33 x $42 \mathrm{~cm}$, respectivamente. A tela de alumínio com malha de 4,5/70\% media $43 \times 30 \mathrm{~cm}$. Os sagüis permaneciam 5 horas na gaiola de ferro colocada no interior desse anteparo sobre o funil e suporte de ferro. Durante esse período receberam suco de maçã. 


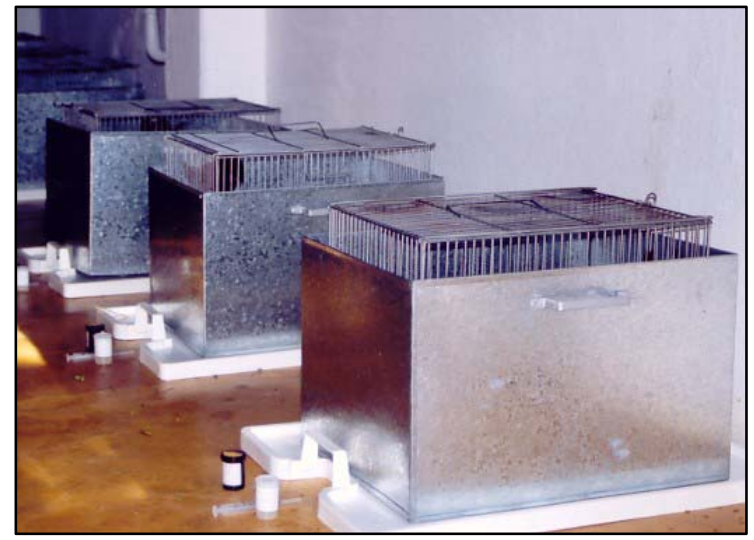

Figura 4 - Disposição das gaiolas, bandejas e anteparos utilizados para coleta de urina e fezes de sagüis controles e sagüis doentes.

Figura 5 - Sistema de coleta da urina para a avaliação da função absortiva do intestino delgado de sagüis.

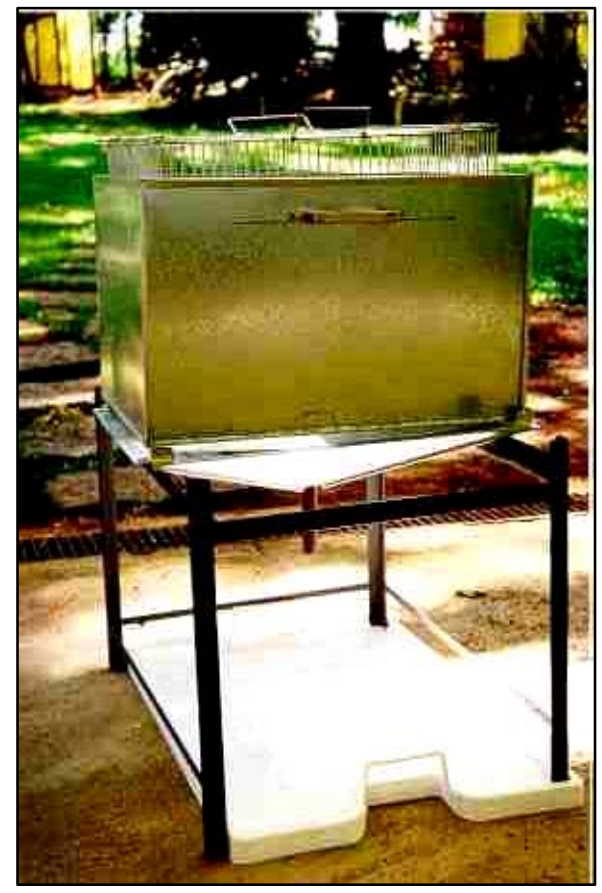

\subsubsection{Processamento das Fezes}

As amostras de fezes foram processadas no Laboratório Clínico de Pesquisa, Departamento de Clínica Médica, da Faculdade de Medicina Veterinária e Zootecnia da 
Universidade de São Paulo (FMVZ-USP) segundo metodologias descritas por BIRGEL (1983), COLES (1986) e HALL (1999). As mesmas foram adequadas por nós ao tamanho das amostras. O processamento das fezes foi realizado entre 12 e 48 horas após a coleta das mesmas.

Foram efetuados os seguintes exames laboratoriais de fezes

1. exame coprológico funcional com avaliação macroscópica, microscópica e pesquisa da atividade proteolítica fecal em tubo de gelatina, cujos protocolos estão descritos no Anexo 1.

2. Coproparasitológico para pesquisa de ovos leves e pesados de parasitos nematóides e protozoários, conforme métodos encontrados no Anexo 2.

\subsubsection{Processamento da urina}

As amostras de urina foram processadas no Laboratório Clínico de Pesquisa, Departamento de Clínica Médica, FMVZ-USP, segundo metodologias descritas por BIRGEL (1983), EBERTS et al. (1979) e McNEELY (1987) e que foram adequadas por nós ao volume das amostras. Os exames laboratoriais foram realizados entre 12 e 24 horas após a coleta da urina.

\subsubsection{Exame de urina Tipo I}

O exame de urina Tipo I compreendeu: exames dos aspectos físicos, químicos e do sedimento urinário. A metodologia está descrita no Anexo 3. 
4.5.3.2. - Teste de Absorção de D-xilose

A função absortiva do intestino delgado foi avaliada de forma indireta pelo Teste de absorção de D-xilose, cujo princípio se baseia na determinação de xilose livre no material biológico após administração oral de dose $500 \mathrm{mg} / \mathrm{Kg}$ de peso, em solução $10 \%$ de D-xilose e coleta de urina total durante 5 horas (EBERTS et al., 1979 e McNEELY,1987). O critério para definir disfunção absortiva do jejuno foi semelhante ao usado para humanos, ou seja, eliminação de D-xilose inferior a 16\% da dose administrada (HAWKINS, 1995).

O protocolo laboratorial usado para avaliação da função absortiva do intestino delgado está descrito no Anexo 4.

\subsection{EXAME ANATOMOPATOLÓGICO, MORFOMÉTRICO E IMUNO-HISTOQUÍMICO}

\subsubsection{Exame anatomopatológico qualitativo e semiquantitativo}

Os sagüis com sinais de SEP que foram a óbito (grupo I) e os controles (grupo III), foram necropsiados no Laboratório de Patologia Comparada de Animais Selvagens do Departamento de Patologia, FMVZ-USP, conforme técnica padrão de exame macroscópico de pequenos mamíferos não ruminantes.

Os fragmentos, de todos os órgãos, colhidos para exame histopatológico, no decorrer da necrópsia, foram fixados em formol a $10 \%$ e processados nos Laboratórios de Histologia do Departamento de Patologia, FMVZ-USP e do Departamento de Patologia da Faculdade de Medicina (FM-USP). Os mesmos foram incluídos em parafina e, posteriormente, seccionados em cortes de aproximadamente $5 \mu \mathrm{m}$ de espessura e corados por hematoxilina e eosina. Os 
segmentos do trato gastrintestinal, em particular o jejuno, foram processados isolados dos demais órgãos, sendo feitos cortes transversais e longitudinais.

O exame histológico das lâminas foi realizado em microscopia de luz, com aumentos de 40,100 e 400x.

O padrão histológico intestinal de normalidade foi definido segundo os mesmos critérios descritos para o homem e para o sagüi-de-tufo-branco (MIRAGLIA et al., 1967; STERNBERG, 1998).

As alterações intestinais, observadas no jejuno, foram avaliadas em 20 jejunos de sagüis que apresentaram sinais de SEP e em oito de sagüis controles quanto a: relação vilo/cripta, tamanho da vilosidade, hiperplasia da cripta, intensidade do infiltrado inflamatório na lâmina própria, tipo de infiltrado inflamatório (mononucleares, neutrófilos e eosinófilos) e densidade de linfócitos intraepiteliais. A presença de ulceração e de agente infectoparasitários foi avaliada com relação à ocorrência ou não do evento.

A intensidade das alterações observadas no jejuno foi avaliada semiquantitativamente na escala de 0 a 3, onde: 0 = parâmetro tido como dentro da normalidade, $1=$ alterações mínimas, 2 = alterações em grau moderado e 3 = grau máximo de alteração.

\subsubsection{Análise morfométrica do jejuno}

A análise morfométrica dos fragmentos de jejuno foi efetuada em sete controles e 10 animais que apresentaram sinais de SEP, utilizando o software para análise de imagem ImagePro ${ }^{\circledR}$ Express versão 4.5 para Windows, edição de 2002. Em cada caso foram capturados 10 campos seqüenciais dos fragmentos de jejuno corados em HE no aumento de 40x. Em cada campo capturado foi aplicada grade de $1 \mathrm{~mm}^{2}$ para contagem de pontos relativos a densidade de volume de cada parâmetro a ser analisado e foram contadas apenas as intersecções 
(WEIBEL \& GOMES, 1962). A Figura 6 mostra um exemplo de como a metodologia foi empregada.

Os seguintes parâmetros foram quantificados: espessura da mucosa (somatória das médias dos pontos contados em relação ao total de pontos da grade utilizada), altura da vilosidade, tamanho das criptas e espessura da lâmina própria intestinal.

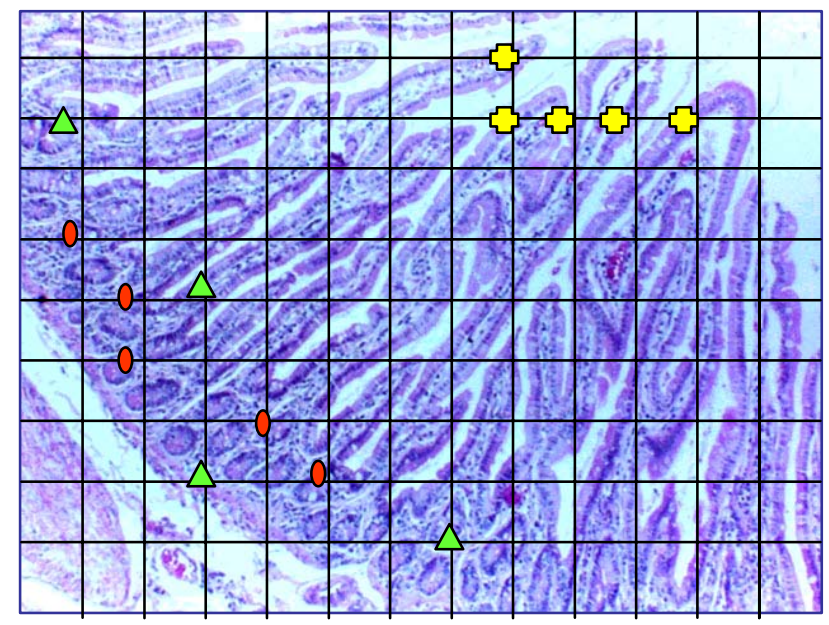

Figura 6 - Exemplo da metodologia usada para contagem dos pontos de intersecção no fragmento de jejuno de sagüis controles e sagüis com SEP, onde marcação em amarelo $=$ área de vilo, em vermelho = área de criptas e em verde = área de lâmina própria. Grade $=1 \mathrm{~mm}^{2}$.

\subsubsection{Análise imuno-histoquímica da resposta imune no jejuno}

Os fragmentos de jejuno de seis sagüis controles (grupo III) e de 13 sagüis que apresentaram sinais de SEP (grupo I) foram submetidos ao exame imuno-histoquímico junto ao Laboratório da Disciplina de Patologia de Moléstias Transmissíveis do Departamento de 
Patologia, FM-USP. O painel de anticorpos escolhido buscou a determinação imunofenotípica das células inflamatórias da lâmina própria, bem como o perfil de algumas citocinas presentes na mucosa intestinal. O método empregado foi estreptavidina-biotina-peroxidade (HSU \& RAINE, 1981), adaptadas às condições do Laboratório.

O painel de anticorpos utilizado está apresentado na tabela 4, juntamente com a diluição utilizada e sistema de detecção.

Nos fragmentos de jejuno de seis sagüis controles (grupo III) e 13 sagüis com SEP (grupo I), foi realizada a contagem diferencial das células inflamatórias. Para a avaliação das citocinas presentes foram estudados seis casos controles e seis doentes.

Para o estudo das citocinas foram testados inicialmente anticorpos anti-citocinas humanas de utilização rotineira no laboratório, fazendo-se a reação imuno-histoquímica em fragmentos de fígado de sagüis. A obtenção de positividade nos fragmentos de fígado dos sagüis atestou que os anticorpos humanos poderiam ser empregados no material do atual estudo.

Ainda, optamos a seguir por utilizar como controles das reações imuno-histoquímicas tecidos humanos comprovadamente positivos para o evento pesquisado. Assim, os controles escolhidos foram colite crônica inespecífica, positivo para IL 4, IL 2 e TNF- $\alpha$; pênfigo, positivo para IL2 e pneumonite viral, para IL4.

Todas as reações tiveram controles positivo e negativo para atestar a veracidade das mesmas. 
TABELA 4- Painel de anticorpos primários e sistemas de detecção utilizados nas reações de imuno-histoquímica em jejuno de sagüis

\begin{tabular}{lccccc}
\hline $\begin{array}{l}\text { ANTICORPOS } \\
\text { PRIMÁRIOS }^{1}\end{array}$ & $\begin{array}{c}\text { ESPÉCIE } \\
\text { ANIMAL }\end{array}$ & DILUIÇÃO & $\begin{array}{c}\text { CÓDIGO } \\
\text { FABRICANTE }\end{array}$ & $\begin{array}{c}\text { SISTEMA DE } \\
\text { DETECÇÃO }\end{array}$ & $\begin{array}{c}\text { CÓDIGO } \\
\text { FABRICANTE }\end{array}$ \\
\hline Anti LT - CD4 & camundongo & $1: 200$ & Dako/ M 834 & CSA $^{\circledR}$ & Dako/ K 1500 \\
Anti LT - CD8 & camundongo & $1: 20$ & Dako/ M 7103 & Envision $^{\circledR}$ & Dako/ K 1491 \\
Anti - CD68 & camundongo & $1: 50$ & Dako/ M 876 & CSA $^{\circledR}$ & Dako/ K 1500 \\
Anti LB - CD20 & camundongo & $1: 50$ & Dako/ M 755 & LSAB plus $^{\circledR}$ & Dako/ K 0690 \\
Anti LT - CD45RO & camundongo & $1: 50$ & Dako/ M 742 & LSAB plus ${ }^{\circledR}$ & Dako/ K 0690 \\
Anti - proteína S100 & coelho & $1: 500$ & Dako/ Z 311 & LSAB plus $^{\circledR}$ & Dako/ K 0690 \\
Anti - IL2 & cabra & $1: 20$ & R\&D/ AF202NA & Kit Duet SABC $^{\circledR}$ & Dako/ K 492 \\
Anti - IL4 & cabra & $1: 40$ & R\&D/ AB204NA & Kit Duet SABC & Dako/ K 492 \\
Anti - TNF- $\alpha$ & coelho & $1: 300$ & R\&D/ AB210NA & Kit Duet SABC & Dako/ K 492 \\
Anti - IFN- $\gamma$ & coelho & $1: 200$ & R\&D/ MAB285 & Kit Duet SABC $^{\circledR}$ & Dako/ K 492 \\
\hline
\end{tabular}

${ }^{1}$ imunoglobulinas para material humano. $\mathrm{LT}=$ linfócito $\mathrm{T}, \mathrm{LB}=$ linfócito $\mathrm{B}, \mathrm{IL}=$ interleucina, TNF- $\alpha=$ fator de necrose tumoral $\alpha$, IFN- $\gamma=$ interferon $\gamma .{ }^{2}$ anticorpos monoclonais/ camundongo, anticorpos policlonais/ coelho e cabra

4.6.3.1. Imunomarcação das células inflamatórias

Os cortes histológicos de $4 \mu \mathrm{m}$ de espessura foram obtidos a partir de fragmentos de jejuno embebido em parafina e colhidos em lâminas previamente preparadas com solução adesiva de 3 amino-propyltriethoxyl-silane (Sigma Chemical Co., St. Louis, MO/ USA, cód. A 3648).

Os cortes foram, a seguir, desparafinados em dois banhos de xilol a $56^{\circ} \mathrm{C}$ durante 30 minutos e, depois, a temperatura ambiente por 20 minutos. Posteriormente, foram hidratados em seqüência decrescente de etanol, ou seja, etanol absoluto, a 95\% e 70\%, e lavados em água corrente por 5 minutos. Antes da próxima etapa, as lâminas foram lavadas em água destilada. O bloqueio de peroxidase endógena foi realizado em câmara escura com três incubações em 
água oxigenada $3 \%$ por 10 minutos cada. Em seguida, as lâminas foram lavadas em água corrente por 5 a 10 minutos, depois em água destilada e, deixadas em solução tampão de soro fetal bovino (PBS), pH 7.4.

A etapa seguinte foi recuperação antigênica com calor úmido utilizando a panela de vapor Steamer $\left(\mathrm{T}-\mathrm{Fal}{ }^{\circledR}\right)$ deixando as lâminas em tampão citrato $0,01 \mathrm{M}, \mathrm{pH}$ 6,0 pré-aquecido a $85-90^{\circ} \mathrm{C}$, por 20 minutos. Após este período, as cubas de lâminas esfriaram a temperatura ambiente e as mesmas foram lavadas com tampão PBS pH 7,4.

Para o bloqueio de proteínas endógenas, as lâminas foram incubadas com leite desnatado 5\% (leite Molico Nestlé ${ }^{\circledR}$ ) por 30 minutos.

A etapa seguinte constituiu a incubação dos espécimes com os anticorpos primários. Esses foram diluídos em solução de albumina bovina, fração V, a 1\% (BSA, SERVA cód. 11930) acrescida de azida sódica $0,1 \%$ em tampão PBS pH 7,4. O cálculo do volume de anticorpo primário, que foi usado, foi baseado em $100 \mu$ na diluição proposta para cada anticorpo por lâmina. A incubação foi por 24 horas, ou seja, overnight a $4^{\circ} \mathrm{C}$ em câmara úmida.

No dia seguinte, após duas lavagens com tampão PBS pH 7,4 por 5 minutos, procedeu-se incubação com anticorpo secundário anti a espécie animal do anticorpo primário, marcado com biotina. Esta etapa teve a duração de 30 minutos, a $37^{\circ} \mathrm{C}$ e em câmara úmida. $\mathrm{O}$ próximo passo envolveu a incubação do complexo estreptavidina-biotina-peroxidase por 30 minutos a $37^{\circ} \mathrm{C}$ em câmara úmida. Para os anticorpos S 100, CD20 e CD45RO utilizou-se o Sistema LSAB plus ${ }^{\circledR}$ (Dako cód. K 0690) e para o anticorpo CD8 Sistema Envision ${ }^{\circledR}$ (Tabela 4).

No caso dos anticorpos CD4 e CD68, a metodologia foi similar, exceto pela não utilização da etapa de recuperação com citrato $0,01 \mathrm{M}$ em panela de vapor. O sistema de detecção empregado foi o Catalyzed Signal Amplification System (CSA ${ }^{\circledR}$, Dako cód. K 1500). 
A reação imune foi revelada com solução cromógena de diaminobenzidina (DAB, 3,3'- diaminobenzidine, Sigma Chemical Co., St. Louis, MO/ USA, cód. D 5637) 0,03\% acrescida de 1,2 $\mathrm{ml}$ de água oxigenada 3\%. O tempo mínimo de revelação foi 2 minutos com bloqueio em água.

Por fim, os cortes foram lavados em água corrente por 10 minutos, contracorados com Hematoxilina de Harris por 10 segundos, lavados em água corrente, desidratados em etanol e

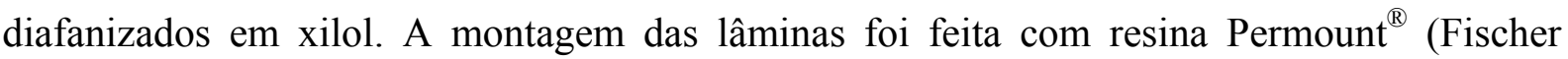
Scientifc, Fair Lawn, NJ/ USA, cód. SP 15-100) e o exame em microscopia de luz.

4.6.3.2. Imunomarcação de citocinas em material parafinado

Os cortes histológicos de $4 \mu \mathrm{m}$ de espessura foram obtidos a partir de fragmentos de jejuno embebidos em parafina e colhidos em lâminas previamente preparadas com solução adesiva de 3 amino-propyltriethoxy-silane (Sigma Chemical Co., St. Louis, MO/ USA, cód. A 3648). A seguir, os cortes foram desparafinados em banhos com xilol e hidratados em seqüência decrescente de etanol, depois lavados em água corrente e água destilada, como anteriormente descrito. Seguiu-se bloqueio da peroxidase endógena com três passagens, por 10 minutos cada, em solução de água oxigenada 3\% em câmara escura. As lâminas foram lavadas em água corrente por 5 minutos, água destilada e tampão PBS, pH 7.4.

A exposição antigênica para citocinas foi realizada com solução de tripsina $0,02 \%$ em tampão PBS, pH 7.4, durante 15 minutos a temperatura ambiente. As lâminas foram lavadas em água corrente por 5 minutos, água destilada e tampão PBS pH 7.4 por pelo menos 5 minutos. Então, os espécimes foram lavados em tampão PBS contendo saponina 0,1\% (Sigma Chemical Co., St. Louis, MO/ USA, Cód. S 7900) durante 10 minutos a temperatura 
ambiente. A próxima etapa foi constituída da lavagem com água destilada e manutenção das lâminas em tampão PBS pH 7.4 por 5 minutos. A incubação das lâminas foi realizada com leite desnatado $10 \%$ (Leite Molico Nestlé ${ }^{\circledR}$ ) em água destilada por 30 minutos a temperatura ambiente.

A incubação com anticorpo primário, previamente diluído em BSA 1\%, foi overnight a $4^{\circ} \mathrm{C}$ em câmara úmida. No dia seguinte, a lavagem dos espécimes foi realizada com tampão PBS pH 7.4 por 10 minutos. Essa etapa foi seguida pela lavagem em PBS acrescido de saponina $0,1 \%$ durante 10 minutos. Depois lavagem em PBS pH 7.4 por 10 minutos e a incubação do anticorpo secundário do Kit Duet $\mathrm{SABC}^{\circledR}$ (Dako, cód. K 492), na diluição 1:800 em PBS acrescido de saponina $0,1 \%$ por 45 minutos a $37^{\circ} \mathrm{C}$ em câmara úmida. Após esse período, foi feita lavagem em PBS pH 7.4 por 10 minutos, lavagem em PBS acrescida de saponina $0,1 \%$ por 10 minutos e, então, lavagem em PBS pH 7.4 por 10 minutos.

O segundo bloqueio de peroxidase endógena foi realizado com três incubações com água oxigenada 3\% por 10 minutos em câmara escura. Em seguida, lavagem em água corrente por 5 minutos e lavagem em água destilada por 5 minutos e tampão PBS pH 7.4 por 10 minutos.

A incubação com o complexo estreptavidina-biotina diluído 1:1000 em PBS foi por 30 minutos a $37^{\circ} \mathrm{C}$ em câmara úmida. Após essa etapa as lâminas foram colocadas em PBS pH 7.4 por 10 minutos. A revelação foi feita com $\mathrm{DAB}$ como descrita anteriormente. 
4.6.3.3. Contagem das células imunomarcadas

A contagem das células imunomarcadas foi realizada em microscopia óptica utilizando retículo graduado com $1 \mathrm{~cm}^{2}$, cuja área é $0,0625 \mathrm{~mm}^{2}$ sob a objetiva de 400x. Assim, as células imunomarcadas foram contadas em 10 campos seqüenciais no aumento de 400x.

Foi calculado o valor médio de células imunomarcadas por campo para cada fenótipo pesquisado. Chegou-se ao número de células positivas por área dividindo-se esse valor médio pela área de $0,0625 \mathrm{~mm}^{2}$. A Figura 7 apresenta exemplo de como foi realizado o cálculo do total de células/ $\mathrm{mm}^{2}$.

A partir desses dados, determinou-se a somatória do conjunto de células imunomarcadas/ $\mathrm{mm}^{2}$ que expressavam os fenótipos estudados na lâmina própria do jejuno. Posteriormente, calculou-se a distribuição relativa percentual dessas células nos jejunos dos sagüis controle (grupo III) e dos sagüis com SEP (grupo I).

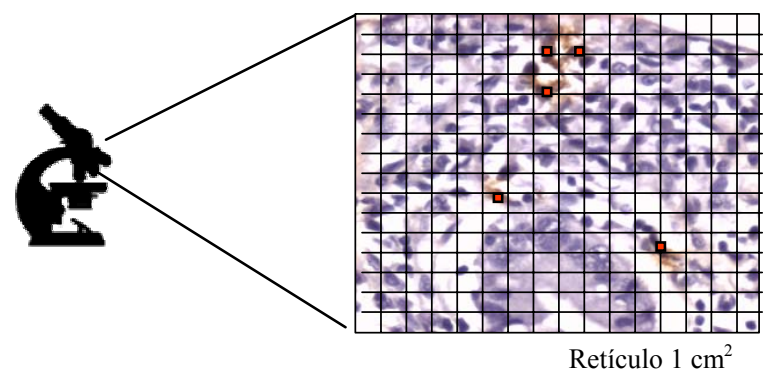

Ex.: Foram contadas 2, 5, 4, 1, 2 células imunomarcadas/ campo 400x, totalizando 14 células em 5 campos e, assim, a média de células por campo foi 2,8 . O total de células por área chegou-se dividindo 2,8/ $0,0625 \mathrm{~mm}^{2}$ resultando em 44,8 células/ $\mathrm{mm}^{2}$.

Figura 7 - Exemplo da metodologia imuno-histoquímica (método estreptavidinabiotina-peroxidase) aliada a método morfométrico para contagem de células imunomarcadas/ $\mathrm{mm}^{2}$ em jejunos de sagüis. Marcação em vermelho = células imunomarcadas. 


\subsection{ANÁLISE ESTATÍSTICA}

Os eventos quantitativos foram analisados usando Teste de Mann-Whitney ou Teste $\mathrm{t}$ de Student para comparação entre dois grupos não paramétricos ou paramétricos, dada a heterogeneidade de variâncias das amostras. Dados de freqüências foram analisados pelo Teste Exato de Fisher, dada a relativa freqüência de caselas com valor menores que dois. Todos os testes foram feitos utilizando análise bicaudal, pelo programa GraphPad Prism ${ }^{\circledR}$ versão 3.00, 1999, para Windows. Em todos os testes, os resultados foram considerados significantes para $p<0,05$. 


\section{RESULTADOS}

\subsection{CARACTERÍSTICAS GERAIS DOS SAGÜIS ACOMETIDOS POR SEP}

A SEP acometeu calitriquídeos pertencentes às espécies sagüi-de-tufo-preto, sagüi-detufo-branco, sagüi-de-cara-branca e híbridos de forma semelhante. A distribuição dos sagüis com SEP, grupo I, segundo as espécie estudadas está apresentada no gráfico 1.

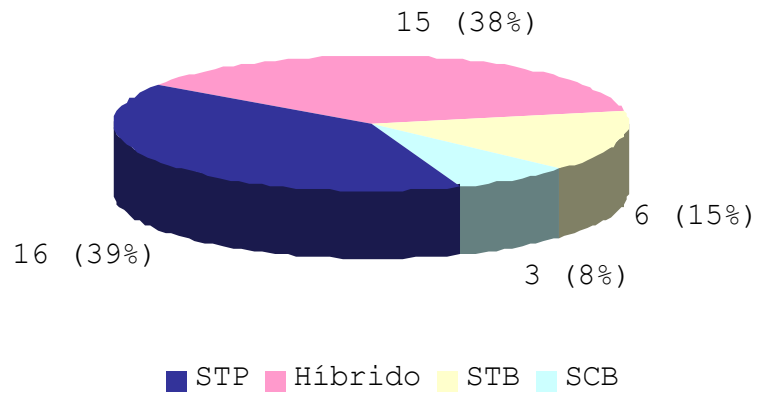

$\mathrm{STP}=$ sagüi-de-tufo-preto, Híbrido = sagüi híbrido, STB = sagüi-de-tufo-branco, SCB = sagüi-de-cara-branca.

Gráfico 1 - Distribuição dos sagüis com SEP (grupo I) segundo as espécies estudadas

Não há predisposição quanto ao sexo. A distribuição dos sagüis com SEP (grupo I) está apresentada, segundo o sexo no gráfico 2. A idade média dos sagüis doentes foi $57,48 \pm$ 21,20 meses. 


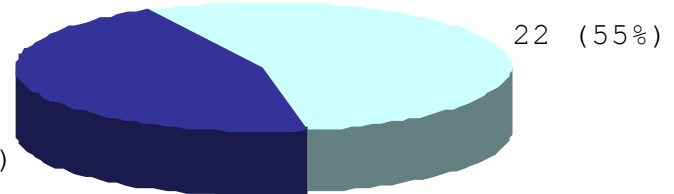

macho fêmea

Gráfico 2 - Distribuição dos sagüis com SEP (grupo I) segundo o sexo

Quanto ao local de nascimento, a maioria, 63\%, dos sagüis nasceu no Criadouro Mucky. A distribuição dos sagüis segundo o local de nascimento está apresentada no gráfico 3. O tempo médio de cativeiro dos sagüis com SEP no Criadouro Mucky foi $49,40 \pm 24,92$ meses.

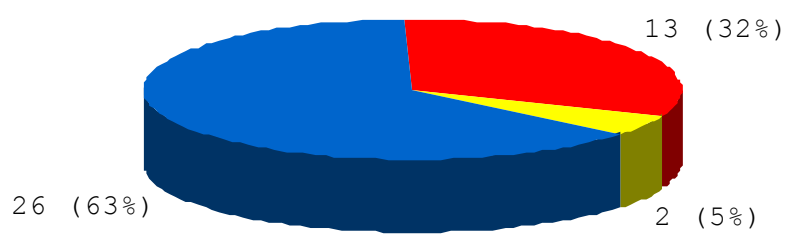

aucky Indeterminado Cativeiro

Mucky $=$ Criadouro Mucky, Cativeiro $=$ outro cativeiro diferente do Criadouro Mucky.

Gráfico 3 - Distribuição dos sagüis com SEP segundo o local de nascimento 
A avaliação da genealogia dos casos indicou a presença de sagüis com laços consangüíneos que desenvolveram SEP. Dos 40 casos analisados, 26 apresentaram pais conhecidos e nascidos no Criadouro Mucky. Desses, 15 possuíam parentesco com uma fêmea de sagüi-de-tufo-branco procedente de vida livre, sendo seis parentes de $1^{\mathrm{a}}$ geração, ou seja, filhos; oito de $2^{\mathrm{a}}$, netos, e um, de $3^{\mathrm{a}}$, bisneto. Doze desses descendentes eram híbridos. Outros dois casos (22 e 29) resultaram do cruzamento entre irmãos, e as respectivas mães (casos 21 e 18) e o pai (caso 27) fazem parte dos casos de SEP analisados.

A SEP apresentou acometimento familiar uma vez que: cinco dos pais e sete das mães dos casos estudados foram a óbito devido a SEP; nove sagüis apresentaram irmão mais velho doente e, 18, tiveram irmãos da mesma ninhada com sinais de SEP.

Com relação ao grupo controle (grupo II), dois eram netos da mesma fêmea referida anteriormente e dois eram parentes, irmão e filho, de sagüis com SEP. Os demais quatro faziam parte de outras famílias de sagüis pertencentes ao criadouro Mucky.

\subsection{DIETA UTILIZADA NO CRIADOURO MUCKY}

\subsubsection{Alimentos usados em maior freqüência}

Os alimentos ofertados em maior freqüência em pelo menos 10 meses foram, em ordem decrescente: leite, batata, “cereal” (farinha-láctea ${ }^{\circledR}$, sustagem ${ }^{\circledR}$, pão-francês, pão-demel-sem chocolate e bolacha-de-maisena, analisados em conjunto), cenoura, abobrinha, frango, ovos, maçã, banana, chuchu, mamão, uva e macarrão.

O gráfico 4 mostra a distribuição dos itens utilizados com maior freqüência, segundo a média mensal. 


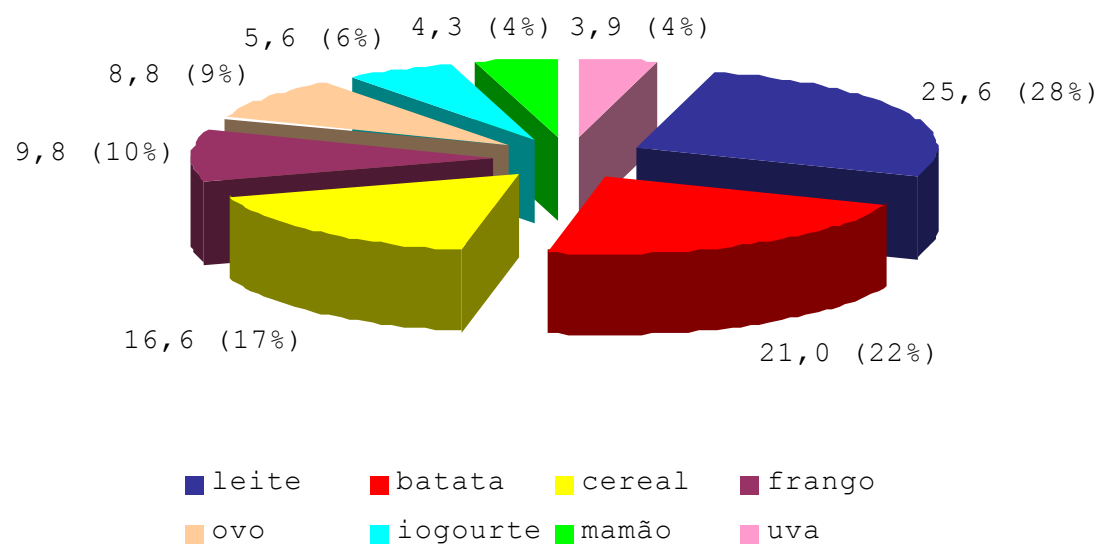

Gráfico 4 - Distribuição dos itens utilizados com maior freqüência na dieta dos sagüis do Criadouro Mucky durante os meses do ano 2000, segundo a média mensal

A dieta apresentou variação na freqüência de oferta de itens ao longo do ano e os gráficos 5 a 8 ilustram a distribuição dos principais itens por mês durante o ano 2000. As causas dessa variabilidade foram relacionadas com disponibilidade de recursos financeiros e sazonalidade dos alimentos, como as frutas. 


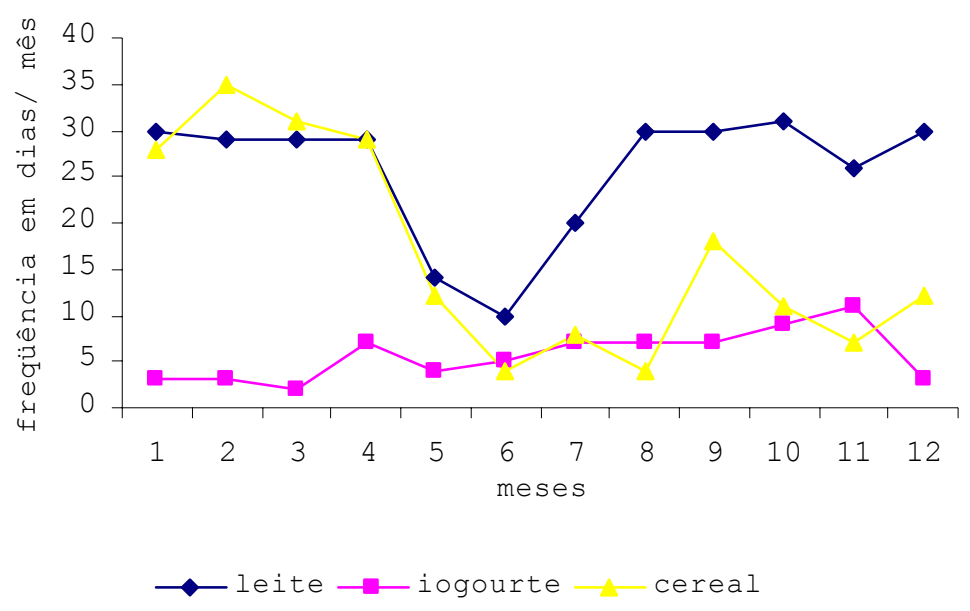

Gráfico 5 - Distribuição dos itens presentes em maior freqüência na $1^{a}$ refeição dos sagüis do Criadouro Mucky

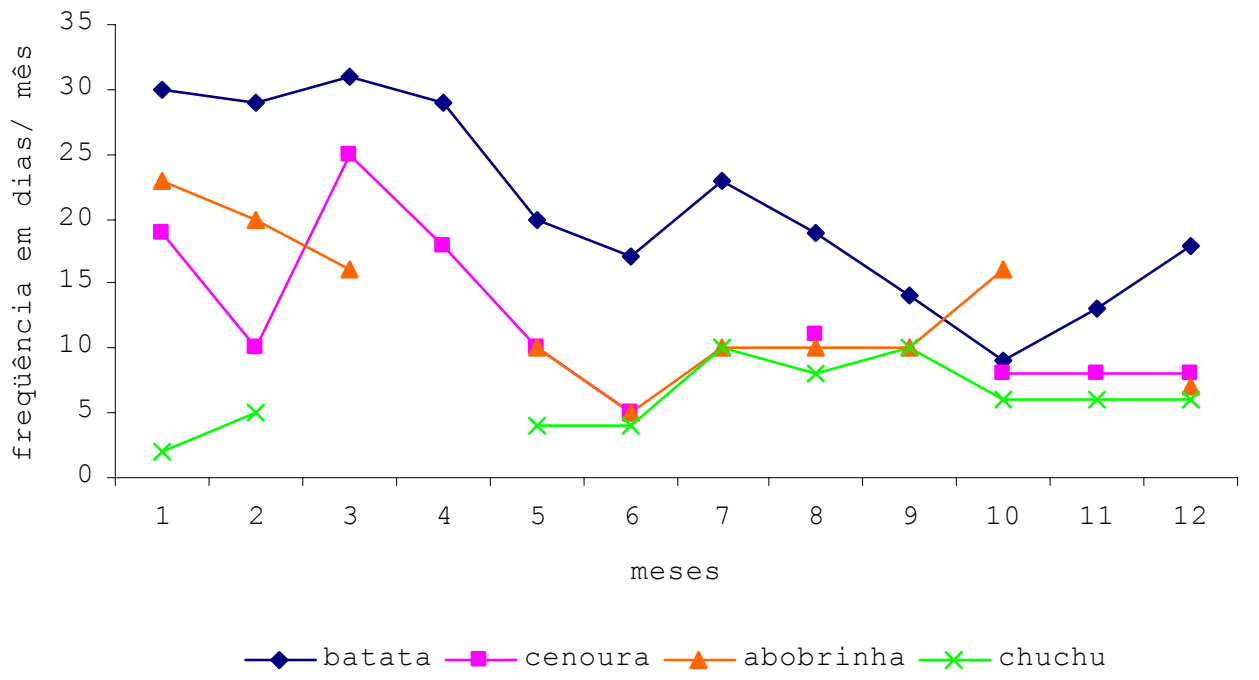

Gráfico 6 - Distribuição dos legumes presentes em maior freqüência na $2^{\mathrm{a}}$ refeição dos sagüis do Criadouro Mucky 


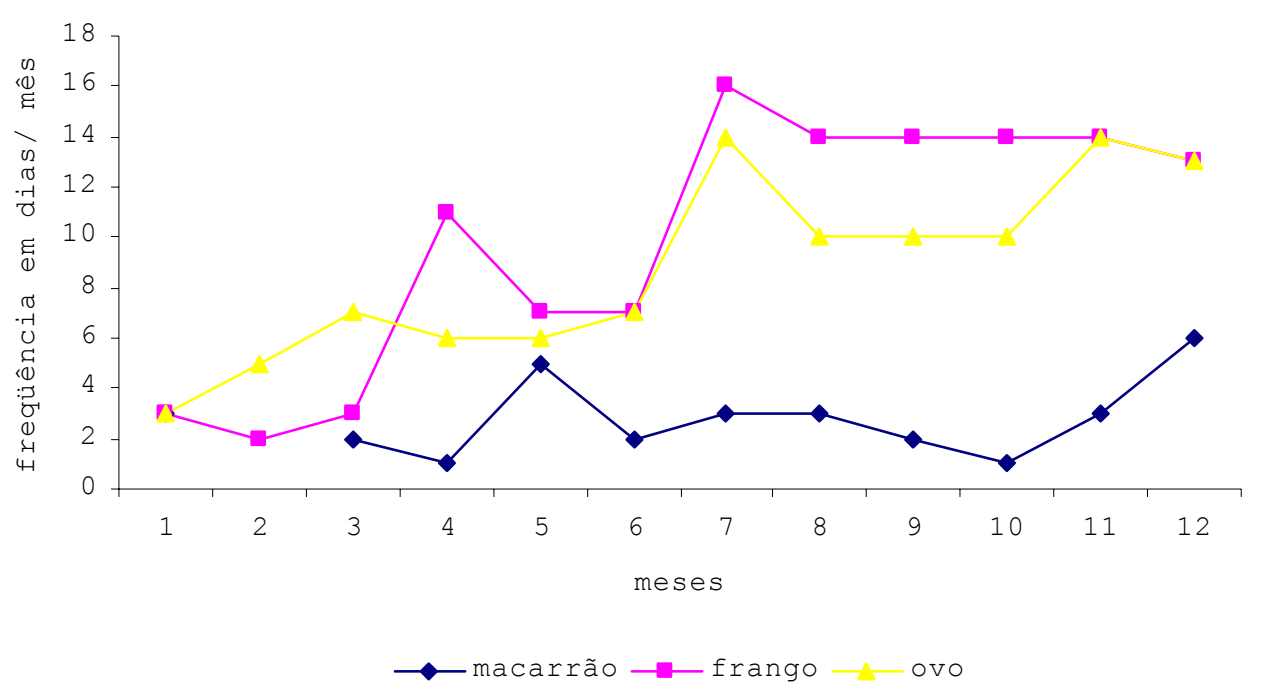

Gráfico 7 - Distribuição da carne de frango, ovos e macarrão presentes na $2^{\mathrm{a}}$ refeição dos sagüis do Criadouro Mucky

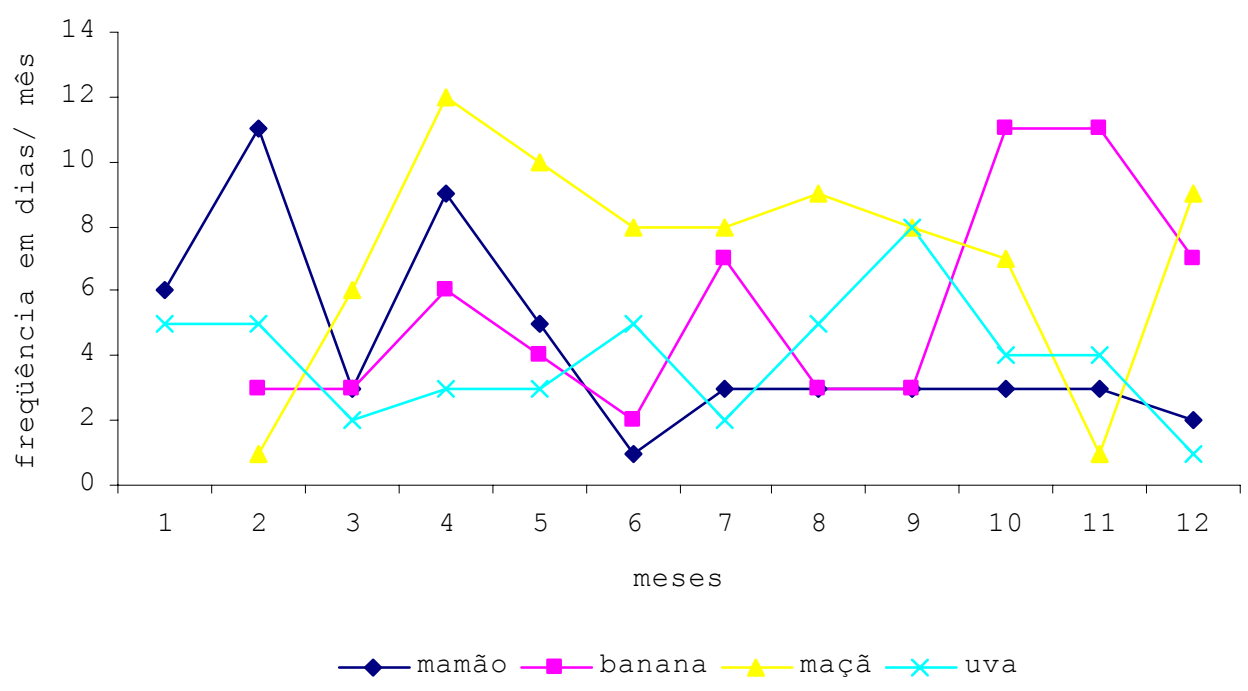

Gráfico 8 - Distribuição das frutas mais freqüentemente presentes na $3^{\mathrm{a}}$ refeição dos sagüis do Criadouro Mucky 


\subsubsection{Composição nutricional da dieta consumida}

A composição nutricional da dieta efetivamente consumida, sobre $100 \%$ de matéria seca, pelos sagüis controles e sagüis com sinais de SEP, quanto aos parâmetros proteína bruta, extrato etéreo, fibra bruta, matéria mineral e extrativo não nitrogenado está apresentada na tabela 5. A análise estatística da composição nutricional da dieta efetivamente consumida não apresentou diferença entre os sagüis controles e sagüis com sinais de SEP ( $p>0,05$, Teste $t$ Student), indicando que não houve diferença no consumo dos alimentos oferecidos entre estes e possibilitando análise em conjunto. A média de consumo de matéria original foi 71,7 gramas por sagüi/ dia e o consumo de matéria seca foi $15,47 \pm 2,68$ gramas por sagüi/ dia.

Tabela 5 - Composição da dieta efetivamente consumida, sobre $100 \%$ da matéria seca, pelos sagüis pertencentes ao Criadouro Mucky, durante 10 dias de experimento

\begin{tabular}{cccccc}
\hline Animal & PB (\%) & EE (\%) & FB (\%) & MM (\%) & ENN (\%) \\
\hline 1 & 17,26 & 2,57 & 1,31 & 2,39 & 76,47 \\
2 & 19,19 & 3,17 & 1,58 & 2,21 & 73,85 \\
3 & 12,00 & 1,18 & 1,12 & 2,78 & 82,92 \\
4 & 20,74 & 3,99 & 2,81 & 1,74 & 70,72 \\
5 & 17,89 & 2,67 & 1,11 & 2,42 & 75,91 \\
6 & 16,65 & 2,27 & 0,89 & 2,56 & 77,63 \\
7 & 15,39 & 2,24 & 1,75 & 2,36 & 78,26 \\
8 & 14,64 & 1,88 & 1,26 & 2,56 & 79,66 \\
9 & 16,28 & 2,31 & 1,27 & 2,46 & 77,68 \\
10 & 13,68 & 1,77 & 1,65 & 2,49 & 80,41 \\
\hline Média & 16,37 & 2,41 & 1,48 & 2,40 & 77,35 \\
Desvio Padrão & 2,59 & 0,78 & 0,54 & 0,28 & 3,43 \\
\hline
\end{tabular}

$\mathrm{PB}=$ proteína bruta, $\mathrm{EE}=$ extrato etéreo, $\mathrm{FB}=$ fibra bruta, $\mathrm{MM}=$ matéria mineral e $\mathrm{ENN}=$ extrativos não nitrogenados 
Assim, a composição nutricional, sobre a matéria seca, da dieta originada do cálculo de consumo médio de todos os sagüis durante o período de 10 dias de experimento está na tabela 6.

Tabela 6 - Composição nutricional, sobre a matéria seca, da dieta originada do cálculo de consumo médio de 10 sagüis durante os 10 dias de experimento

\begin{tabular}{ll}
\hline Nutriente & \\
\hline Proteína bruta & $16,37 \%$ \\
Energia metabolizável & $3,96 \mathrm{Kcal} / \mathrm{g}$ \\
Extrato etéreo & $2,41 \%$ \\
Fibra bruta & $1,48 \%$ \\
Extrativos não nitrogenados & $77,35 \%$ \\
Matéria mineral & $2,40 \%$ \\
\hline
\end{tabular}

A dieta efetivamente consumida mostrou porcentagem de proteína, energia metabolizável (3,96 Kcal/ gramas de MS) dentro do preconizado no NRC 2003.

\subsubsection{Avaliação quantitativa da eficiência digestiva}

A avaliação quantitativa da eficiência digestiva dos sagüis doentes foi realizada com comparação dos coeficientes de digestibilidade da dieta padronizada. O consumo dessa dieta entre o grupo de sagüis controles e sagüis doentes não foi estatisticamente diferente ( $p$ > 0,05), como apresentado no item 5.2.2. 
Os coeficientes de digestibilidade aparente (\%) da matéria seca, proteína bruta, extrato etéreo, extrativo não nitrogenado e matéria mineral estão mostrados na tabela 7 para os sagüis controles e para os sagüis com sinais de SEP.

Tabela 7 - Coeficientes de digestibilidade aparente (\%) calculados para os sagüis controles e com SEP

\begin{tabular}{|c|c|c|c|c|c|}
\hline \multicolumn{6}{|c|}{ DA (\%) Animais Controles } \\
\hline Sagüis & MS & PB & EE & ENN & MM \\
\hline 1 & 84,50 & 80,14 & 88,26 & 87,53 & 90,04 \\
\hline 2 & 89,86 & 84,74 & 94,48 & 93,61 & 82,26 \\
\hline 3 & 88,02 & 83,23 & 89,69 & 92,09 & 74,09 \\
\hline 4 & 83,47 & 72,98 & 54,36 & 88,59 & 84,69 \\
\hline Média & 86,46 & 80,27 & 81,70 & 90,46 & 82,77 \\
\hline Desvio padrão & 2,99 & 5,23 & 18,42 & 2,87 & 6,64 \\
\hline Coeficiente de variação & 3,46 & 6,51 & 22,54 & 3,17 & 8,02 \\
\hline \multicolumn{6}{|c|}{ DA (\%) Animais com SEP } \\
\hline Sagüis & MS & PB & EE & ENN & MM \\
\hline 1 & 82,35 & 70,15 & 64,19 & 88,54 & 62,62 \\
\hline 2 & 78,68 & 54,14 & 8,24 & 87,14 & 43,13 \\
\hline 3 & 77,66 & 57,45 & 45,00 & 86,50 & 37,64 \\
\hline 4 & 78,17 & 62,54 & 59,27 & 85,79 & 51,31 \\
\hline Média & 79,22 & 61,07 & 44,18 & 86,99 & 48,68 \\
\hline Desvio padrão & 2,13 & 6,97 & 25,30 & 1,17 & 10,86 \\
\hline Coeficiente de variação & 2,69 & 11,41 & 57,28 & 1,34 & 22,31 \\
\hline Teste T & 0,02 & 0,02 & 0,07 & 0,07 & 0,01 \\
\hline
\end{tabular}


O cálculo do coeficiente da digestibilidade da fibra bruta foi prejudicado em virtude da baixa concentração de fibras na dieta utilizada e por ter havido contaminação com a ingestão de pelos.

A análise estatística dos coeficientes de digestibilidade aparente (DA) entre os dois grupos mostrou diferença significante quanto à digestão de matéria seca, proteína bruta e matéria mineral ( $\mathrm{p}<0,05$ - Teste $\mathrm{T}$ student pareado), indicando menor capacidade digestiva quanto a esses parâmetros.

\subsection{CARACTERÍSTICAS CLÍNICAS DA SEP}

Os dados obtidos no primeiro exame físico e último anterior ao óbito ou ao final do período de estudo foram analisados.

Os sagüis com SEP apresentaram alterações clínicas: gastrintestinais, hematológicas, neuro-musculares, reprodutivas, comportamentais e cutâneas.

Emagrecimento progressivo, diarréia e fezes volumosas pastosas intermitentes (analisadas em conjunto), e distensão abdominal foram os sinais clínicos gastrintestinais mais freqüentemente observados com 90\%, 77,5\% e 57,5\%, respectivamente (Figuras 8 e 10).

Outros sinais clínicos relacionados á digestão observados foram: fezes aumentadas de volume e pastosas com forma definida (20\%), alteração do apetite, variando de hiporexia $(10 \%)$ a polifagia $(10 \%)$, emese $(5 \%)$ e anasarca $(12,5 \%)$.

Outras alterações clínicas foram constatadas como anemia, pela observação de mucosas hipocoradas, em 70\% dos casos, petéquias e sufusões em $2,5 \%$.

As alterações neuro-musculares se caracterizaram por perda progressiva de massa muscular que acompanhou o emagrecimento (90\%); alteração da marcha observada pela 
diminuição do reflexo proprioceptivo dos membros posteriores (10\%) com dígitos sobrepostos e posicionados semelhantes a "patas-de-aranha"; dismetria (25\%), e paralisia dos membros posteriores $(10 \%)$ que foi caracterizada pela incapacidade de agarrar, ou de flexionar os membros posteriores mediante estímulo doloroso e permanência em decúbito lateral ou esternal (Figuras 11 a 13). A observação de tremores cefálicos intermitentes ou incapacidade de permanecer em estação foi verificada em 5\% dos casos.

As fêmeas emagrecidas e que emprenharam, apresentaram aborto em $2,5 \%$. As alterações comportamentais, como diminuição da atividade motora diária, apatia ou prostração, foram verificadas em 17,5\%.

As alterações cutâneas (32,5\%) incluíram pelos arrepiados, descamação furfurácea do dorso, rarefação pilosa da cauda ou dos membros, inclusive dos dígitos, hiperpigmentação das regiões caudal dos membros posteriores e da região abdominal lateral; pelame de má qualidade, com pelos sem brilho, curtos, amarronzados, oleosos ou ressecados, e com nós.

Os sinais clínicos da SEP foram divididos, considerando as maiores freqüências, em sinais maiores e menores. Esses estão apresentados na tabela 8. 
Tabela 8 - Sinais clínicos maiores e menores observados nos sagüis com SEP

\begin{tabular}{lc}
\hline Sinais clínicos maiores & $\%$ \\
\hline Perda de peso progressiva & 90 \\
Diarréia e fezes volumosas pastosas intermitentes & 77,5 \\
Mucosa hipocorada & 70 \\
Distensão abdominal & 57,5 \\
\hline Sinais clínicos menores & $\%$ \\
\hline Alteração cutânea & 32,5 \\
Alteração da marcha & 25 \\
Fezes aumentadas de volume e pastosas com forma definida & 20 \\
Alteração comportamental (prostração/ apatia) & 17,5 \\
Anasarca & 12,5 \\
Diminuição da propriocepção dos membros posteriores & 10 \\
Paralisia dos membros posteriores & 10 \\
Hiporexia & 10 \\
Polifagia & 10 \\
Tremor cefálico & 5 \\
Emese & 5,5 \\
Petéquias/ sufusões & 2,5 \\
\hline Aborto & \\
\hline
\end{tabular}


5.4. AVALIAÇÃO LABORATORIAL DA SEP

\subsubsection{Exame coprológico funcional}

O exame coprológico funcional revelou diferenças significativas em relação à presença de fezes com aumento de volume e consistência pastosa $(\mathrm{p}<0,01$ ), odor nauseabundo/ fermentativo $(\mathrm{p}<0,05)$ e presença de gordura $(\mathrm{p}<0,05)$ (Figura 14). Na tabela 9 estão apresentados os resultados do exame coprológico funcional das fezes de sagüis com SEP (grupo I) e sagüis controles (grupo II).

Tabela 9 - Exame coprológico funcional das amostras de fezes dos sagüis com SEP (grupo I) e sagüis controles (grupo II)

\begin{tabular}{lccc}
\hline Fezes & $\begin{array}{c}\text { Grupo I } \\
\text { sagüis c/ SEP } \\
(\mathrm{N}=21)\end{array}$ & $\begin{array}{c}\text { Grupo II } \\
\text { controles } \\
(\mathrm{N}=9)\end{array}$ & $\begin{array}{c}\text { Significância } \\
\text { estatística }{ }^{1} \\
\text { Valor de } p\end{array}$ \\
\hline Peso médio (gramas) & $4,70 \pm 3,09$ & $3,49 \pm 1,85$ & NS \\
Pastosas/ volumosas & $71,42 \%$ & $22,23 \%$ & $<0,01$ \\
Cor castanha & $52,38 \%$ & $66,67 \%$ & NS \\
Cor amarela & $47,62 \%$ & $11,12 \%$ & NS \\
Odor nauseabundo/ fermentativo & $52,38 \%$ & $11,12 \%$ & $<0,05$ \\
Presença de alimentos não digeridos & $14,29 \%$ & nenhum & NS \\
Fibras musculares & $33,34 \%$ & nenhum & NS \\
Gotículas de gordura (+ a +++) $)^{2}$ & $52,38 \%$ & nenhum & $<0,05$ \\
Grânulos de amido & $100 \%$ & $100 \%$ & NS \\
Atividade proteolítica fecal em tubo de gelatina & $100 \%$ & $100 \%$ & NS \\
\hline
\end{tabular}

${ }^{1}$ Teste de Fisher. ${ }^{2}$ Coloração de Sudan III. 


\subsubsection{Exame coproparasitológico}

As amostras de fezes dos sagüis com SEP e dos sagüis controles foram negativas para pesquisa de ovos leves e pesados de parasitos nematóides e protozoários nos exames coproparasitológicos.

\subsubsection{Exame de urina Tipo I}

Os sagüis controles apresentaram exame de urina tipo I dentro dos padrões de normalidade. Os sagüis com SEP apresentaram variados graus de alterações do exame de urina Tipo I, incluindo aumento da densidade urinária, proteinúria, hemoglobinúria, leucocitúria, cristalúria e presença de bactérias e leveduras.

\subsubsection{Teste de absorção de D-xilose}

Os testes de absorção de D-xilose realizados em 17 doentes apresentaram percentagem de eliminação inferior a $16 \%$ da dose administrada e os sete controles, todos acima de $16 \%$ (p $<0,001$, Teste de Mann-Whitney). Os resultados alcançados estão mostrados no gráfico 9. 


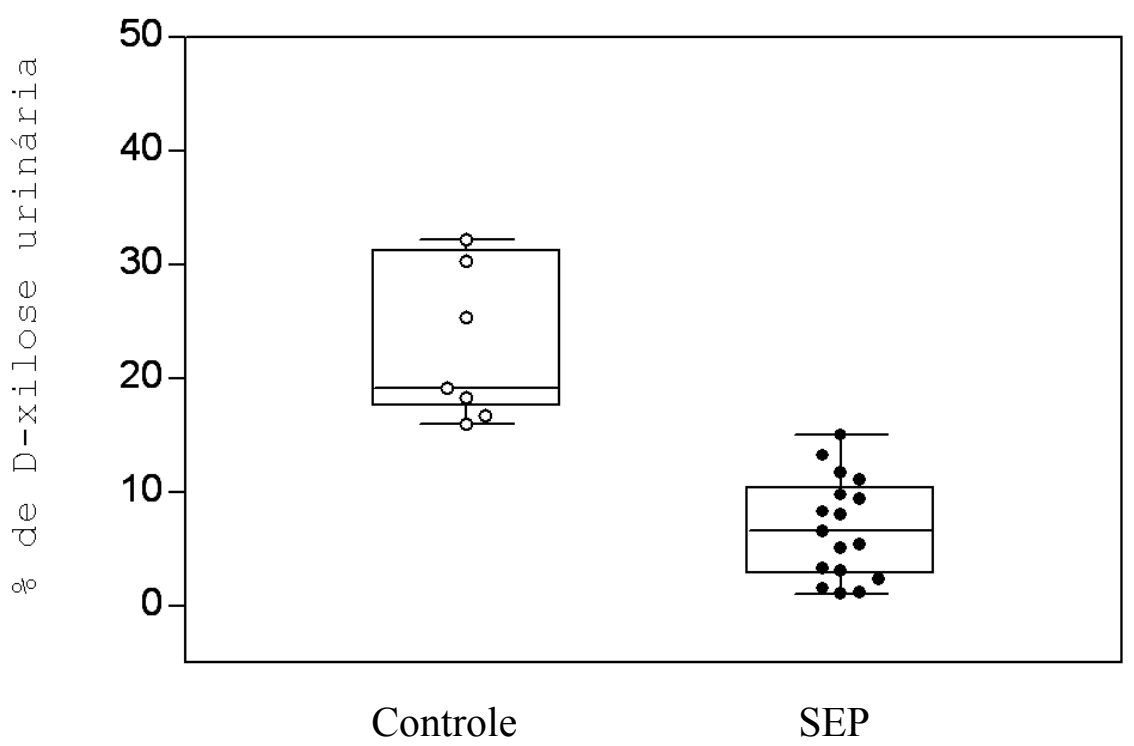

Resultados expressos como porcentagem de D-xilose na urina com dose total de $500 \mathrm{mg} / \mathrm{Kg}$ durante coleta de 5 horas. A caixa representa porcentagem de $50 \%$, a linha interna representa a mediana, as barras de erros os valores mínimo e máximo. As marcas circulares os valores individuais. Os círculos sólidos representam o grupo I, os círculos abertos o grupo II. $(\mathrm{p}<0,001)$. Teste de Mann-Whitney.

Gráfico 9 - Teste de absorção de D-xilose em sagüis controles vivos (grupo II) e sagüis com SEP (grupo I)

\subsection{ANÁLISE ANATOMOPATOLÓGICA}

\subsubsection{Exame macroscópico}

O exame necroscópico, com destaque a condição corpórea e ao sistema digestivo, mostrou nos casos com SEP: emagrecimento caracterizado por ausência de depósitos de gordura subcutânea, redução da musculatura esquelética generalizada chegando, em alguns casos, a caquexia (100\%), palidez das mucosas e dos órgãos (72\%); distensão abdominal devido à dilatação das alças intestinais (72\%); conteúdo pastoso amorfo e amarelado no 
intestino delgado (68\%) (Figura 15 e 16), conteúdo alimentar no estômago (64\%) e presença de conteúdo pastoso amorfo e amarelado no intestino grosso (64\%).

Os resultados macroscópicos dos sagüis com SEP estão apresentados no gráfico 10.

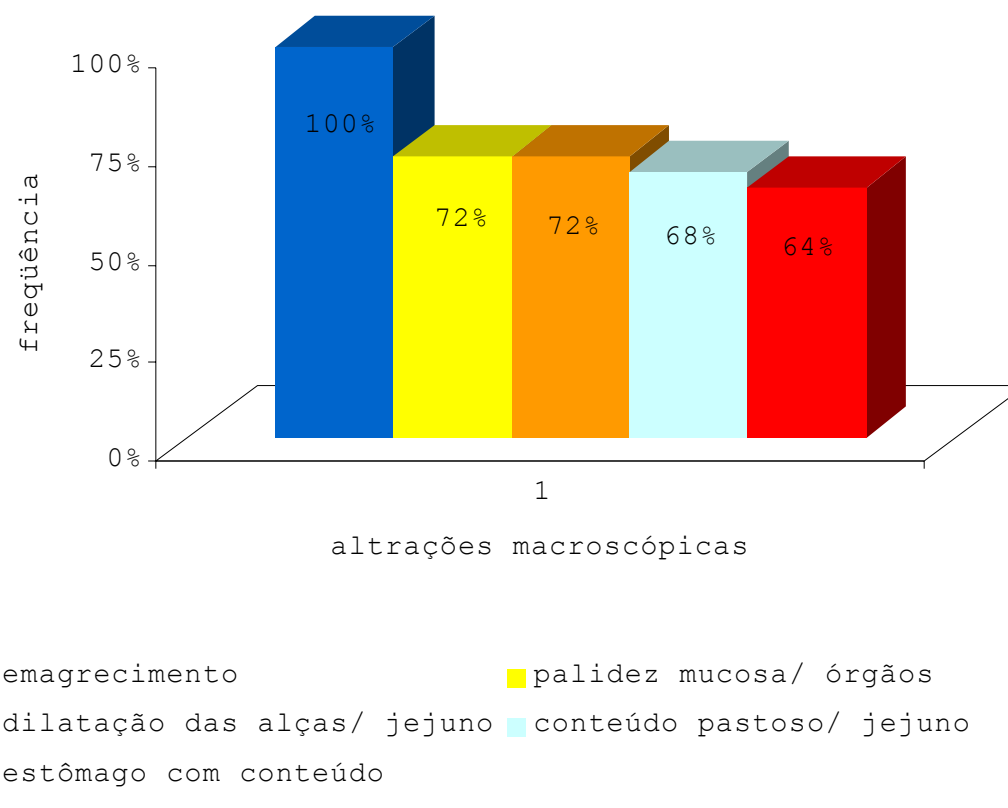

Gráfico 10 - Alterações macroscópicas mais freqüentes nos casos de SEP

\subsubsection{Exame microscópico do intestino delgado}

No exame microscópico do intestino delgado, o achado comum a todos os casos com SEP foi enterite crônica atrófica, com redução parcial ou total do comprimento das vilosidades intestinais, hiperplasia das criptas e importante infiltrado linfocítico plasmocítico na lâmina própria (Figura 17 a 21). Em nenhum dos casos estudados houve encontro de parasitos intestinais.

Os resultados da avaliação histopatológica semiquantitativa está apresentada na tabela 10 (APÊNDICE A). A análise estatística mostrou que houve diferença significante $(\mathrm{p}<$ 
0,001) pra relação vilo/ cripta, comprimento da vilosidade, hiperplasia de cripta, intensidade do processo inflamatório, intensidade do infiltrado mononuclear e densidade de linfócitos intraepiteliais (Gráfico 11).

Não houve diferença estatística dos neutrófilos e eosinófilos na avaliação semiquantitativa (Tabela 10 - APÊNDICE A).

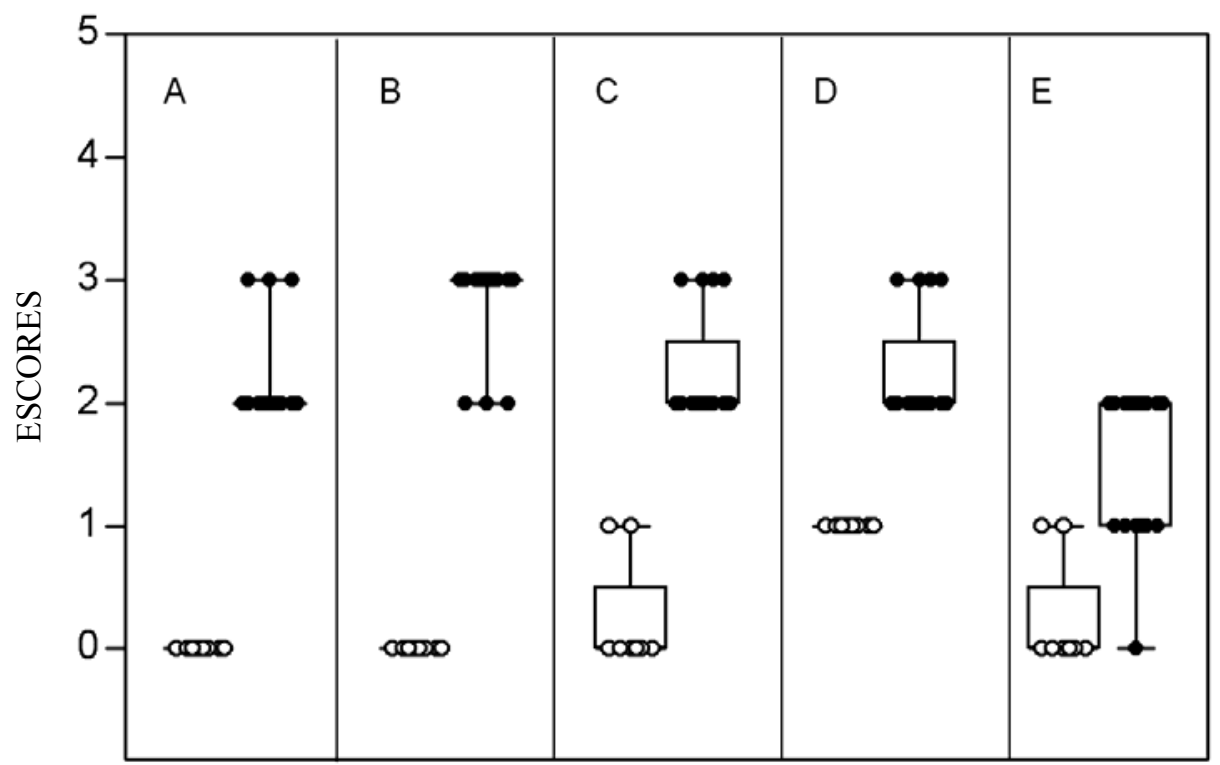

$\mathrm{A}=$ relação vilo/cripta; $\mathrm{B}=$ hiperplasia das criptas; $\mathrm{C}=$ intensidade do infiltrado inflamatório; $\mathrm{D}=$ intensidade do infiltrado de mononucleares; $\mathrm{E}=$ densidade de linfócitos intraepiteliais. A caixa representa porcentagem de 50\%, a linha interna representa a mediana, as barras de erros os valores mínimo e máximo e as marcas circulares os valores individuais. Os círculos sólidos o grupo I; os círculos abertos grupo III. (p < 0,001; Teste de Mann-Whitney e Teste de Fisher)

Gráfico 11 - Análise semiquantitativa da mucosa do jejuno dos sagüis controles (grupo III) e sagüis com SEP (grupo I) 


\subsubsection{Análise morfométrica}

Os resultados da análise morfométrica da mucosa do jejuno estão apresentados na tabela 11.

Tabela 11 - Análise morfométrica da mucosa do jejuno de sagüis com SEP (grupo I) e sagüis controles (grupo III), segundo a densidade de volume (Vv) em área de vilos, área de criptas e lâmina própria

\begin{tabular}{lccc}
\hline Parâmetros & $\begin{array}{c}\text { Grupo I } \\
\text { sagüis com SEP } \\
(\mathrm{n}=10)\end{array}$ & $\begin{array}{c}\text { Grupo III } \\
\text { controles } \\
(\mathrm{n}=7)\end{array}$ & $\begin{array}{c}\text { Significância } \\
\text { Valor de } p\end{array}$ \\
\hline $\begin{array}{c}\text { Espessura da mucosa } \\
\left(\text { pontos } / \mathrm{mm}^{2}\right)\end{array}$ & $59,34 \pm 15,84$ & $73,47 \pm 6,65$ & $>0,05$ \\
Área de vilos $(\mathrm{Vv})$ & $19,07 \pm 6,16$ & $59,66 \pm 4,44$ & $<0,001$ \\
Área de criptas $(\mathrm{Vv})$ & $22,33 \pm 4,59$ & $11,08 \pm 2,05$ & $<0,001$ \\
Lâmina própria $(\mathrm{Vv})$ & $58,19 \pm 6,37$ & $29,26 \pm 4,02$ & $<0,001$ \\
\hline
\end{tabular}

A análise estatística do estudo morfométrico do jejuno mostrou que houve diferença significante entre a densidade de volume de vilos, criptas e da lâmina própria na mucosa do jejuno entre os grupos I e III $(p<0,001)$ e não houve diferença significante $(p>0,05)$ entre as espessuras das mucosas (Teste de Mann-Whitney). O gráfico 12 demonstra esses dados. 


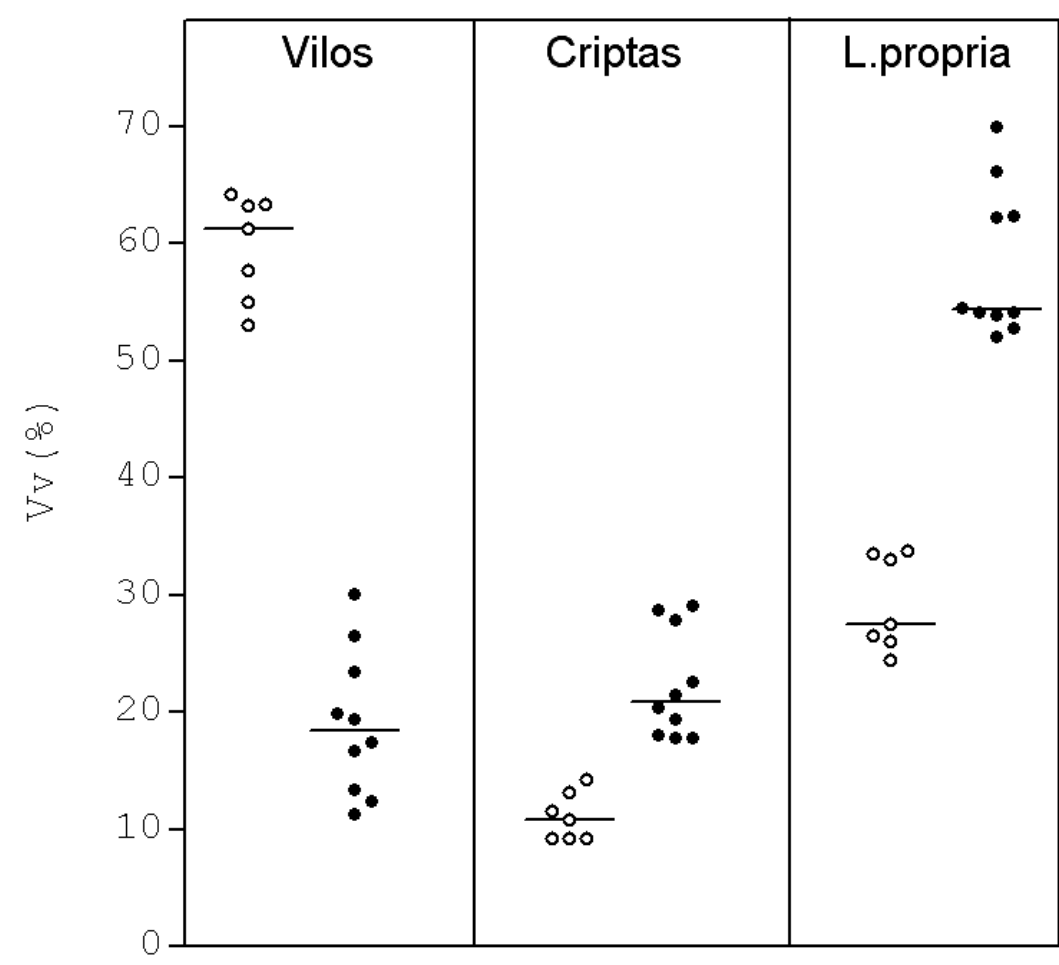

Area

Resultados expressos como porcentagem da densidade de volume (Vv) da área de vilos, área de criptas e de lâmina própria. Barra representa mediana e os círculos os valores individuais. Círculo sólido = grupo I; círculo aberto = grupo III $(\mathrm{p}<0,001$; Teste de MannWhitney).

Gráfico 12 - Análise morfométrica da mucosa do jejuno nos sagüis controle (grupo III) e sagüis com SEP (grupo I)

\subsubsection{Análise da resposta imune no jejuno}

A média das células imunomarcadas para os fenótipos proteína S100+, LB-CD20+, LT-CD45RO+, CD68+ somadas em conjunto foi $294,80 \pm 127,82$ células/ $\mathrm{mm}^{2}$ no jejuno dos sagüis com SEP, sendo aproximadamente duas vezes maior do que a média das células imunomarcadas somadas, para os mesmos fenótipos, no jejuno dos sagüis controles, $160,80 \pm$ 79,65 células $/ \mathrm{mm}^{2}$. 
Os resultados individuais da imunomarcação para os fenótipos das células inflamatórias presentes na lâmina própria do jejuno estão na tabela 12 (APÊNDICE B), para os sagüis controles (grupo III) e para os sagüis com SEP (grupo I).

No jejuno dos sagüis controles (grupo III) a média das células proteína S100+ totalizou 93,07 $\pm 30,95$ células/ $\mathrm{mm}^{2}$ das células imunomarcadas contadas. As médias das demais células contadas foram LB-CD20 + com 45,07 $\pm 38,55$ células/ $\mathrm{mm}^{2}$; células LT$\mathrm{CD} 45 \mathrm{RO}+$ com $20,80 \pm 20,36$ células/ $\mathrm{mm}^{2}$, e as células CD68+ com 1,87 $\pm 0,65$ células/ $\mathrm{mm}^{2}$

No jejuno dos sagüis com SEP (grupo I), as médias das células imunomarcadas contadas para LB-CD20+ foram 126,00 \pm 98,75 células/ $\mathrm{mm}^{2}$; para as células LT-CD45RO+ totalizaram 68,58 $\pm 48,74$ células/ $\mathrm{mm}^{2}$ (Figura 22 e 23); e as células CD68+ somaram 13,78 $\pm 18,07$ células $/ \mathrm{mm}^{2}$ (Figuras 26). Para o fenótipo proteína $\mathrm{S} 100+$ foram contadas $86,28 \pm$ 110,43 células/ $\mathrm{mm}^{2}$ das células imunomarcadas (figura 27). A distribuição das células imunomarcadas para os fenótipos estudados apresentou diferença estatística significante $(\mathrm{p}<$ 0,05) entre os dois grupos com relação à soma das médias das células LT-CD45RO+ e CD68+, com valores médios maiores do que a média dos controles. Com relação às células LB-CD20+ houve aumento nos casos com SEP, porém sem diferença significante $(p=0,07$, Teste de Mann-Whitney).

A representação gráfica da distribuição das médias das células imunomarcadas para os fenótipos proteína $\mathrm{S} 100+$, $\mathrm{LB}-\mathrm{CD} 20+$, LT-CD45RO+, CD68+ na lâmina própria do jejuno dos sagüis controles e dos sagüis com SEP está apresentada no gráfico 13. 


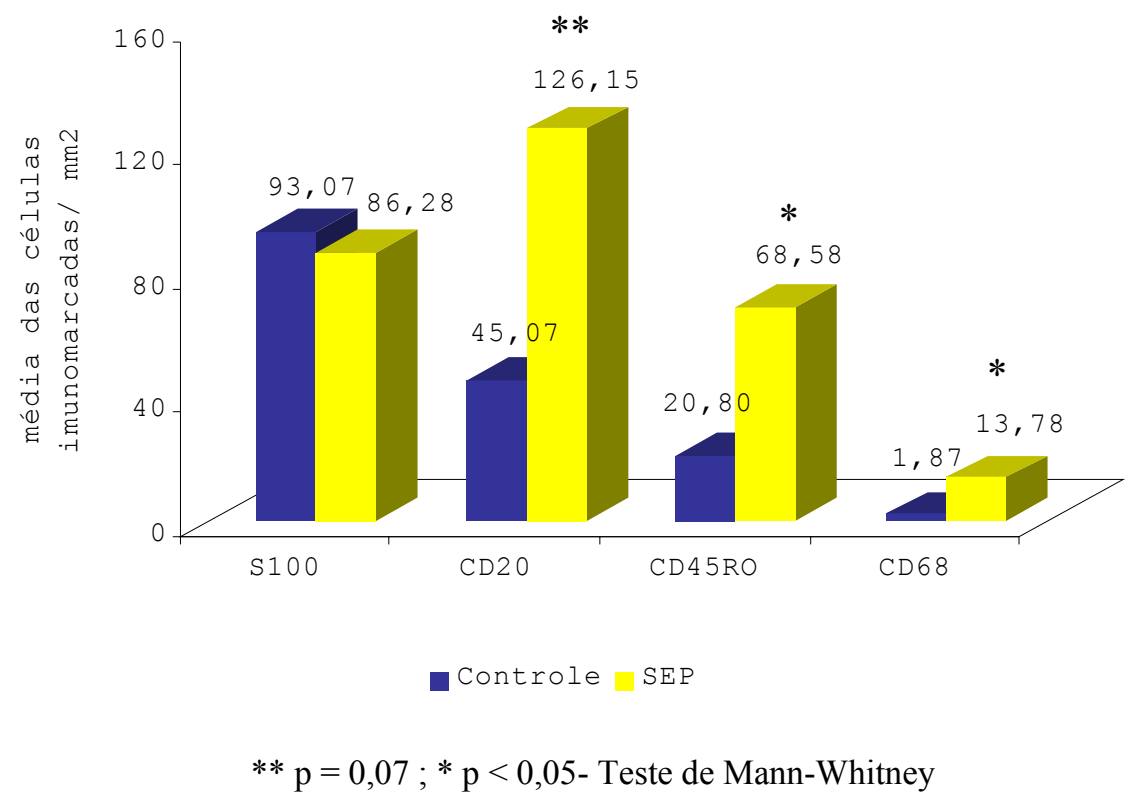

Gráfico 13 - Distribuição das células inflamatórias imunomarcadas na lâmina própria do jejuno de sagüis controles (grupo III) e sagüis com SEP, para os fenótipos proteína S100+, LB-CD20+, CD68+ e LT-CD45RO+

No grupo dos controles (grupo III) foram contados $6,67 \pm 9,78$ células LT- CD8+/ $\mathrm{mm}^{2}$ imunomarcadas, e 7,20 $\pm 6,84$ células LT-CD4+/ $\mathrm{mm}^{2}$ do total das células imunomarcadas. No grupo dos sagüis com SEP (grupo I) foi contado número significante maior de células $(p<0,05): 21,91 \pm 20,76$ células LT-CD8+/ $\mathrm{mm}^{2}$ das células imunomarcadas, e 103,38 \pm 102,96 células LT-CD4+/ mm² (Figuras 24 e 25). No gráfico 14 está a distribuição das células LT-CD8+ e LT-CD4+ para o grupo dos sagüis controles e sagüis com SEP. 


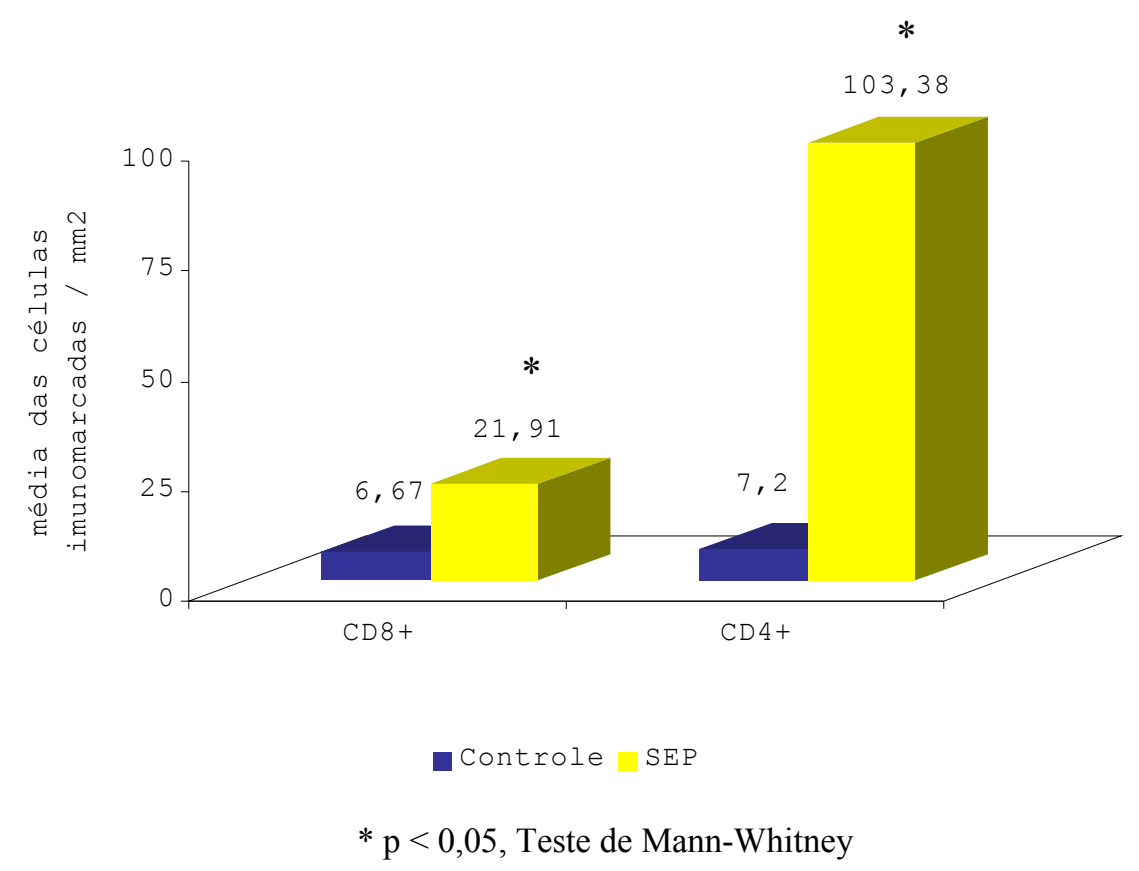

Gráfico 14 - Distribuição de LT-CD8+ e LT-CD4+ imunomarcadas na lâmina própria do jejuno dos sagüis controles (grupo III) e sagüis com SEP (grupo I)

Os resultados individuais da imunomarcação do perfil das citocinas presentes por área $\left(\mathrm{mm}^{2}\right)$ na lâmina própria de jejuno dos casos estudados estão, na tabela 12 (APÊNDICE B) para os sagüis controles (grupo III) e sagüis com SEP (grupo I).

As citocinas presentes na lâmina própria do jejuno dos sagüis controles (grupo III) foram $1,07 \pm 0,83$ células IL2 $+/ \mathrm{mm}^{2}$ e $0,53 \pm 0,83$ células IL4+/ $\mathrm{mm}^{2}$. Não foram detectadas expressão de TNF- $\alpha$ e IFN- $\gamma$. As citocinas presentes na lâmina própria do jejuno dos sagüis com SEP (grupo I) foram 25,33 $\pm 25,25$ células IL2+/ $\mathrm{mm}^{2} ; 1,07 \pm 1,31$ células IL4+/ mm²; $0,80 \pm 0,88$ células TNF- $\alpha+/ \mathrm{mm}^{2}$ e $0,53 \pm 1,31$ células IFN $-\gamma+/ \mathrm{mm}^{2}$ (Figuras 28 a 30). A análise estatística das imunomarcações para citocinas presentes na lâmina própria do jejuno mostrou diferença significante $(\mathrm{p}<0,05)$ entre os grupos apenas quanto à presença de IL2. Esses dados podem ser visualizados no gráfico 15. 


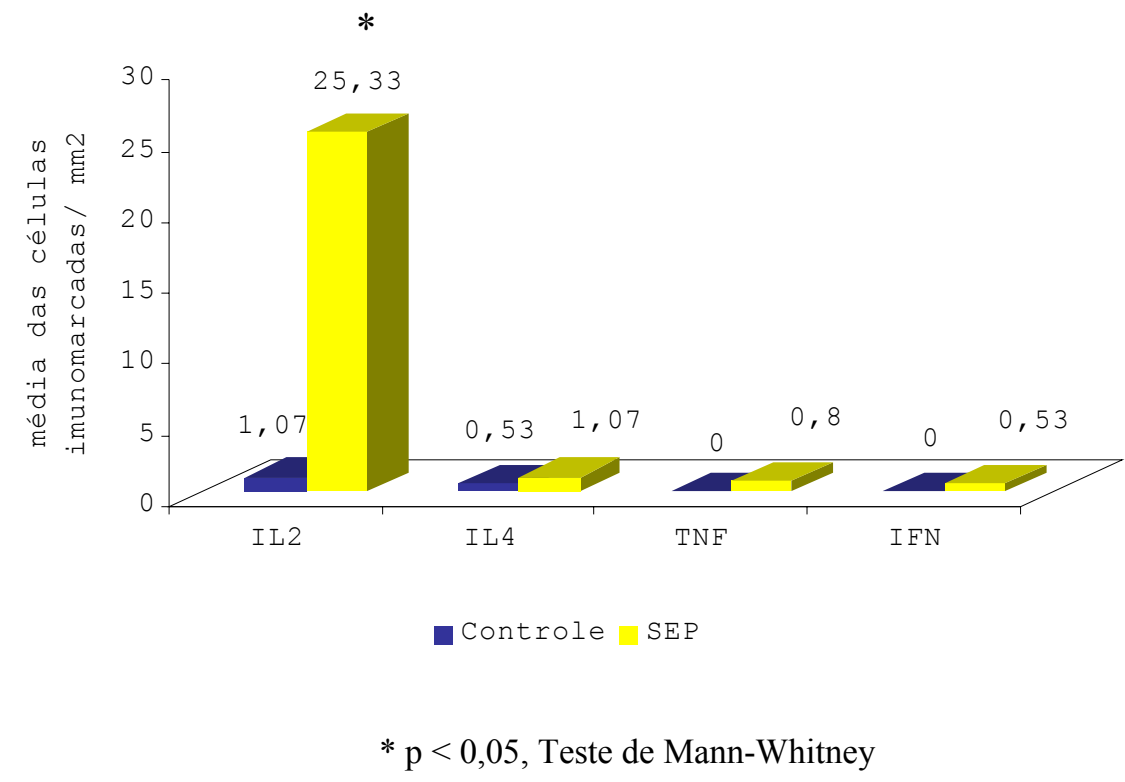

Gráfico 15 - Distribuição das citocinas presentes na lâmina própria do jejuno de sagüis controles (grupo III) e sagüis com SEP (grupo I) 
Figura 8 - Sinal clínico maior da SEP: emagrecimento. Notar o posicionamento dos dígitos. Sagüis híbrido. Criadouro Mucky, São Paulo.

Figura 9 - Sinal clínico maior da SEP: emagrecimento. Notar perda de massa muscular do membro posterior. Sagüi-de-tufo-preto. Criadouro Mucky, São Paulo

Figura 10 - Sinal clínico maior da SEP: distensão abdominal. Sagüi-de-tufobranco. Criadouro Mucky, São Paulo

Figura 11 - Sinal clínico menor da SEP: alteração da marcha, posição em estação. Sagüi híbrido. Criadouro Mucky, São Paulo

Figura 12 - Sinal clínico menor da SEP: alteração da marcha, dismetria. Sagüi híbrido. Criadouro Mucky, São Paulo

Figura 13 - Sinal clínico menor da SEP: paralisia, decúbito esternal. Estado terminal da SEP Sagüi-de-tufo-branco. Criadouro Mucky, São Paulo 

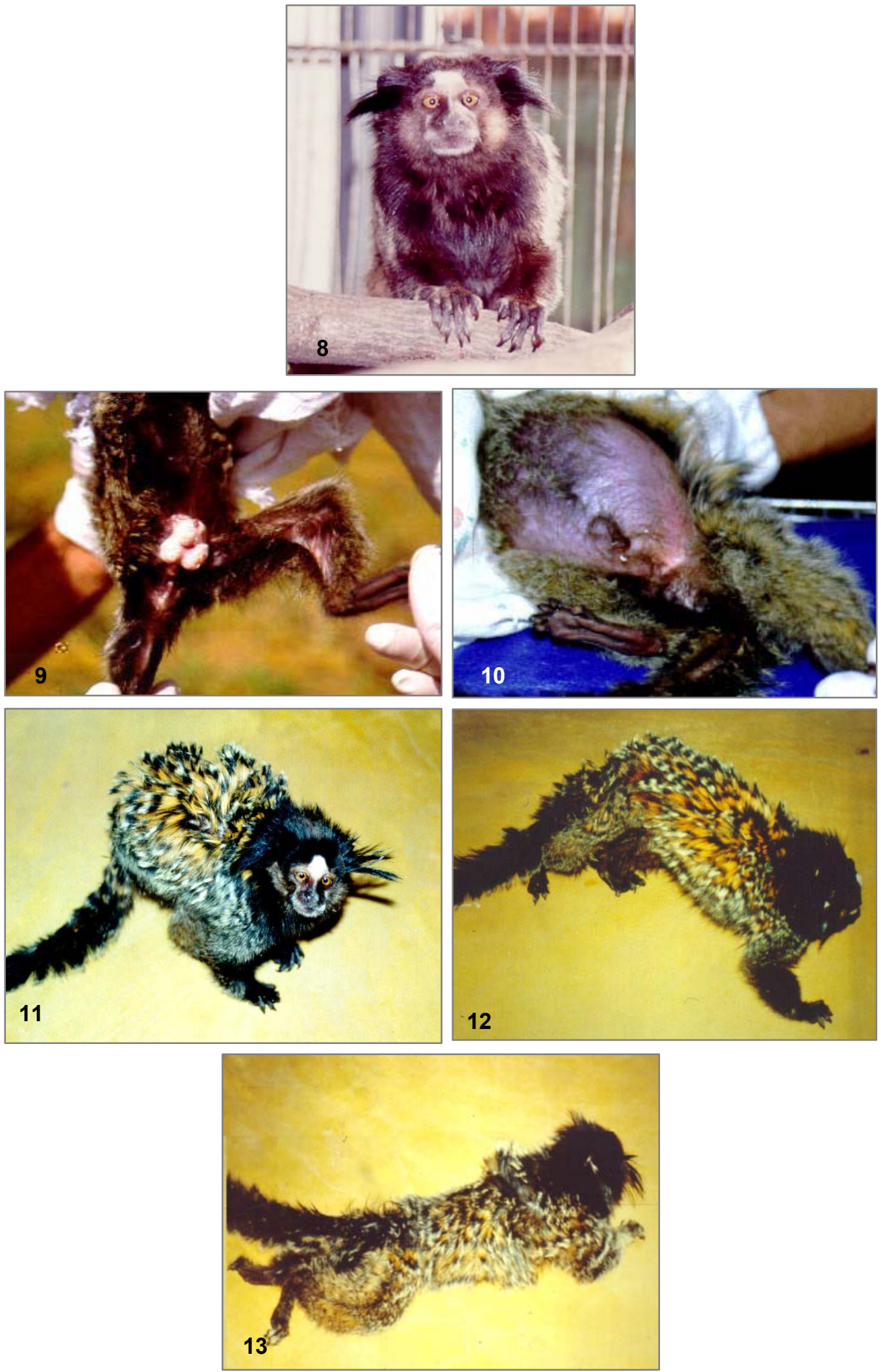
Figura 14 - Gotículas de gordura coradas por Sudan III nas fezes de sagüi com SEP, exame coprológico. Esteatorréia

Figura 15 - Aspecto macroscópico de sagüi com SEP. Notar palidez dos órgãos e distensão abdominal

Figura 16 - Aspecto macroscópico da dilatação das alças intestinais por conteúdo pastoso e amarelado em sagüi com SEP 

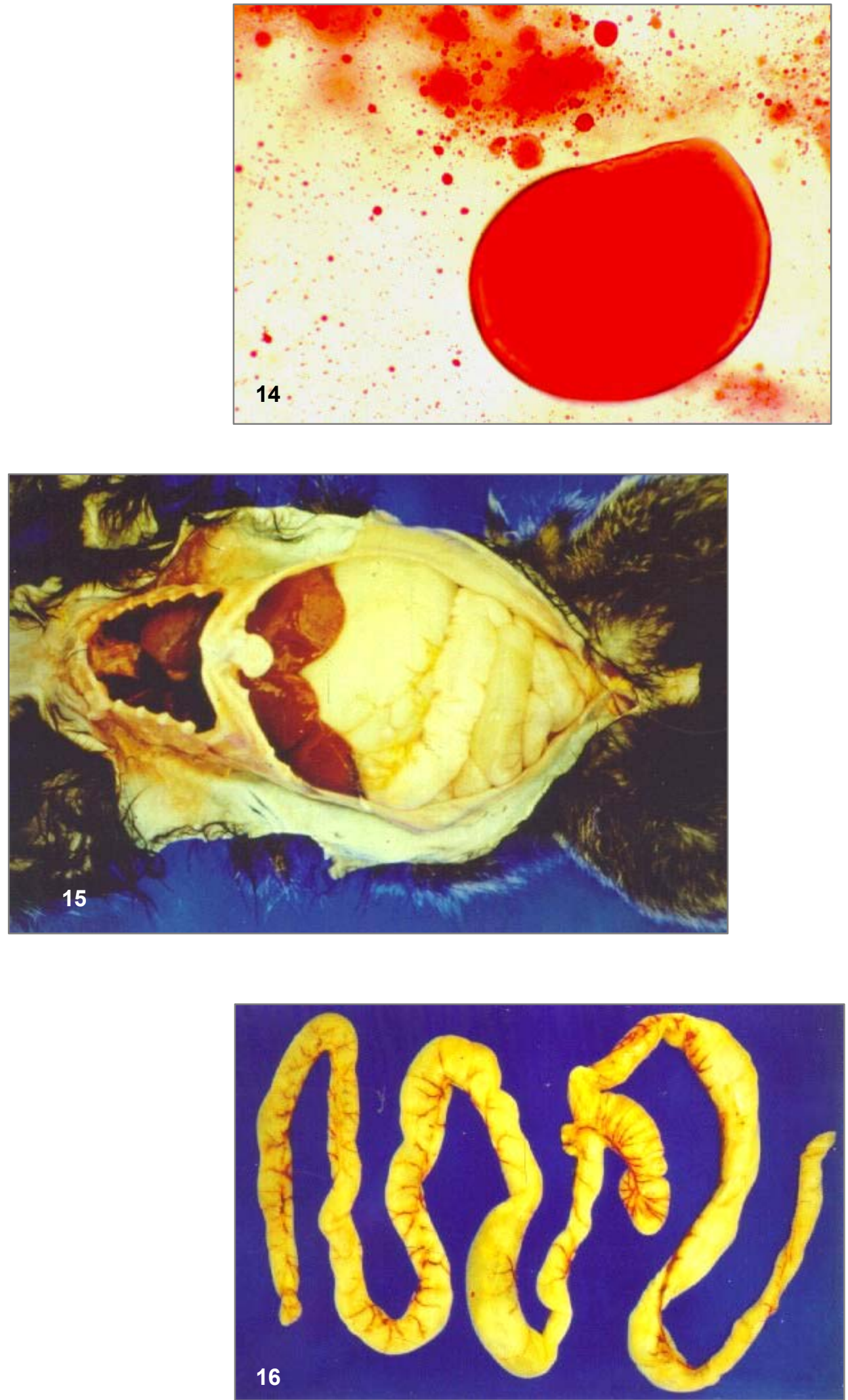
Figura 17 - Fotomicrografia do jejuno de sagüi com SEP. Enterite crônica difusa com atrofia de vilosidades, hiperplasia de criptas e infiltrado linfoplasmocitário na lâmina própria. HE , 40x

Figura 18 - Fotomicrografia do jejuno de sagüi com SEP. Enterite crônica com atrofia de vilosidades, hiperplasia de criptas e infiltrado linfoplasmocitário na lâmina própria. Notar atrofia das vilosidades. HE , 100x

Figura 19 - Fotomicrografia do jejuno de sagüi com SEP. Enterite crônica com atrofia de vilosidades, hiperplasia de criptas e infiltrado linfoplasmocitário na lâmina própria. Notar linfócitos intraepiteliais. HE , 200x

Figura 20 - Fotomicrografia do jejuno de sagüi com SEP. Enterite crônica, Enterite crônica com atrofia de vilosidades, hiperplasia de criptas e infiltrado linfo-plasmocitário na lâmina própria. Notar hiperplasia das criptas com aumento do número de mitoses. HE , 200x

Figura 21 - Fotomicrografia do jejuno de sagüi com SEP. Enterite crônica, infiltrado inflamatório linfo-plasmocitário observado na lâmina própria. HE , 400x 

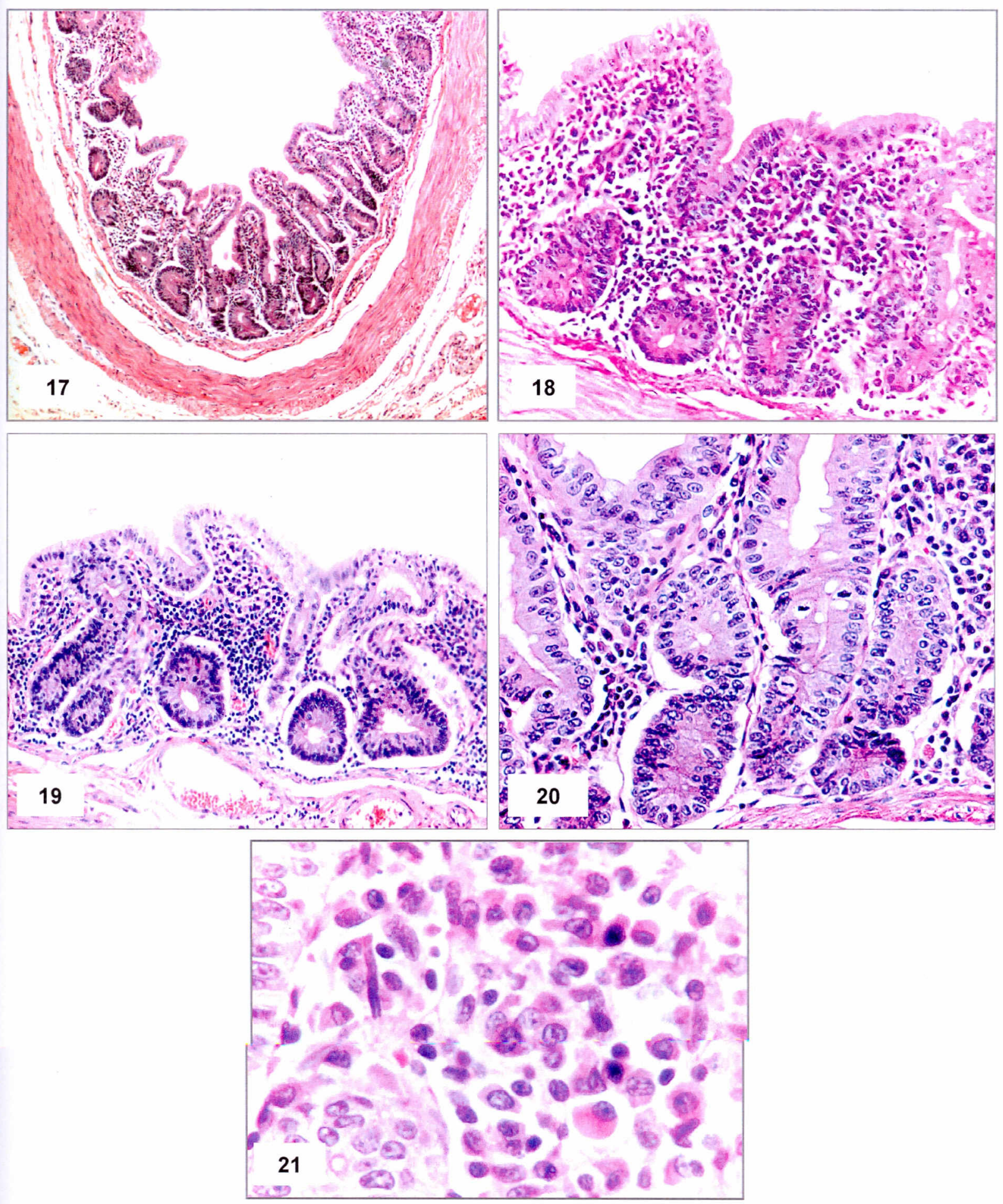
Figura 22 - Fotomicrografia do jejuno de sagüi com SEP. Imunomarcação para linfócitos B-CD20+. Estreptavidina-biotina-peroxidase contra corada por Hematoxilina de Harris. IHQ, 400x

Figura 23 - Fotomicrografia do jejuno de sagüi com SEP. Imunomarcação para linfócitos $\mathrm{T}-\mathrm{CD} 45 \mathrm{RO}+$. Estreptavidina-biotina-peroxidase contra corada por Hematoxilina de Harris. IHQ, 400x

Figura 24 - Fotomicrografia do jejuno de sagüi com SEP. Imunomarcação para linfócitos T-CD4+. Estreptavidina-biotina-peroxidase contra corada por Hematoxilina de Harris. IHQ, 400x

Figura 25 - Fotomicrografia do jejuno de sagüi com SEP. Imunomarcação para linfócitos T-CD8+. Estreptavidina-biotina-peroxidase contra corada por Hematoxilina de Harris. IHQ, 400x

Figura 26 - Fotomicrografia do jejuno de sagüi com SEP. Imunomarcação para células apresentandoras de antígeno, macrófago $\mathrm{CD}_{6}+$. Estreptavidina-biotina-peroxidase contra corada por Hematoxilina de Harris. IHQ, 400x

Figura 27 - Fotomicrografia do jejuno de sagüi com SEP. Imunomarcação para células apresentadoras de antígenos, células dendrítica proteína S100+. Estreptavidina-biotina-peroxidase contra corada por Hematoxilina de Harris. IHQ, 400x 

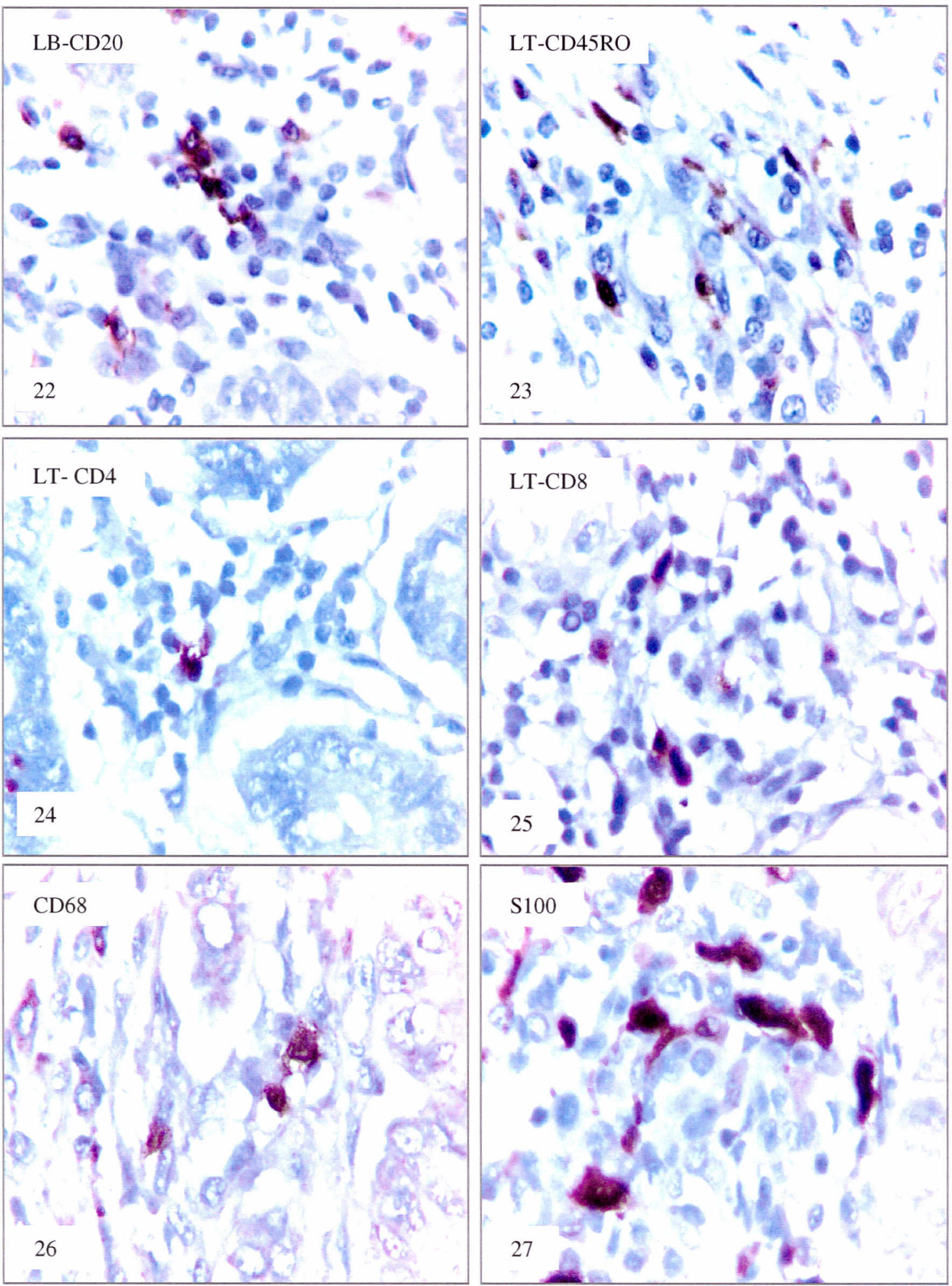
Figura 28 - Fotomicrografia do jejuno de sagüi com SEP. Imuno-expressão de interleucina 2 (IL 2). Resposta imunomediada perfil TH 1. Estreptavidina-biotina-peroxidase contra corada por Hematoxilina de Harris. IHQ, 400x

Figura 29 - Fotomicrografia do jejuno de sagüi com SEP. Imuno- expressão de interferon- $\gamma($ IFN- $\gamma)$. Resposta imunomediada perfil TH 1. Estreptavidinabiotina-peroxidase contra corada por Hematoxilina de Harris. IHQ, 400x

Figura 30 - Fotomicrografia do jejuno de sagüi com SEP. Imuno-expressão de fator de necrose tumoral (TNF- $\alpha$ ). Resposta imunomediada perfil TH 1. Estreptavidina-biotina-peroxidase contra corada por Hematoxilina de Harris. IHQ, 400x 

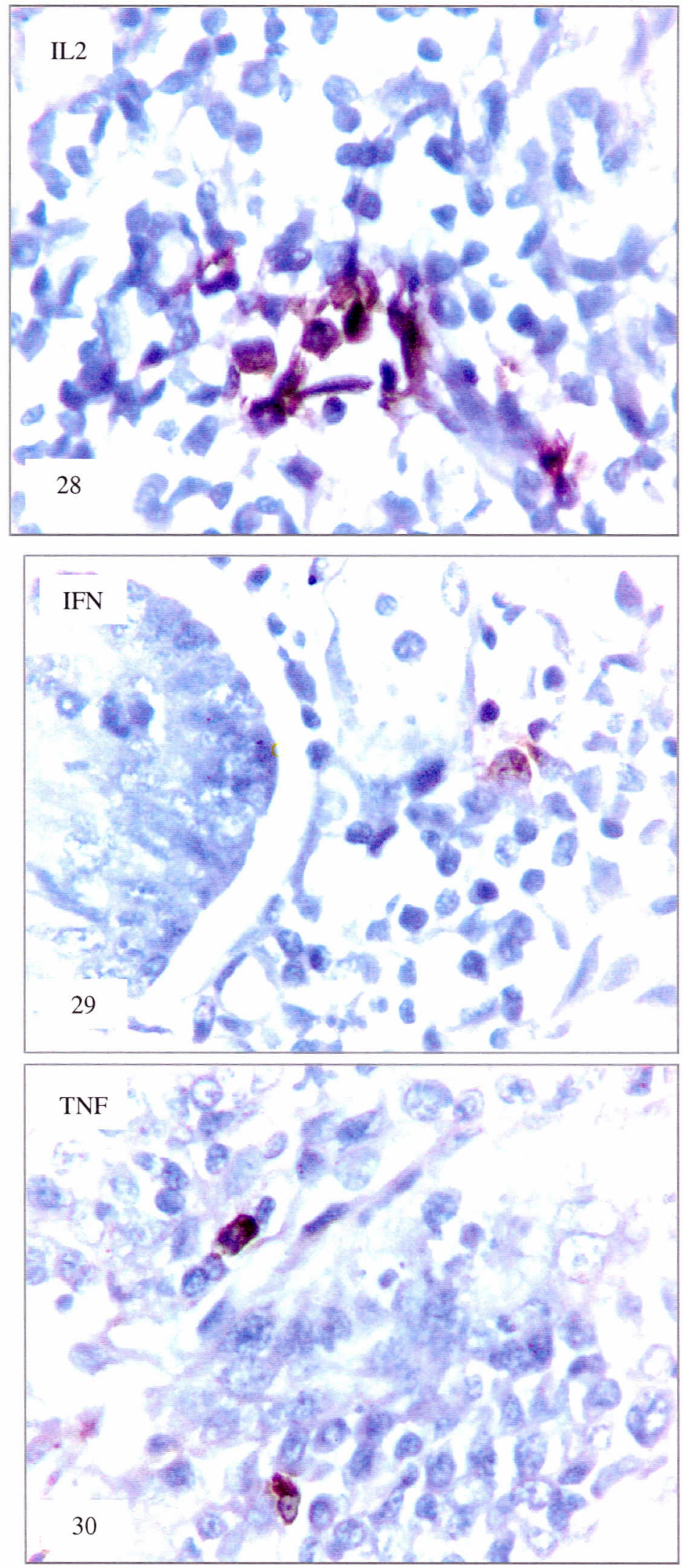


\section{DISCUSSÃO}

O interesse crescente nos calitriquídeos impulsionou o desenvolvimento de numerosos estudos envolvendo animais de cativeiro e da natureza, que proporcionaram ganho relevante de conhecimento geral sobre algumas espécies. Conseqüentemente, os possíveis benefícios advindos da criação de sagüis em cativeiro ficaram evidentes, tanto do ponto de vista conservacionista como biomédico. Por outro lado, a manutenção de sagüis no cativeiro ainda envolve dificuldades e desafios, principalmente, no controle de enfermidades que ocasionam elevada morbidade e mortalidade desses pequenos primatas.

A SEP começou a chamar a atenção de pesquisadores por volta de 1975 em decorrência do número de sagüis que adoeciam e morriam. Atualmente, continua sendo considerada a doença de maior impacto sobre as colônias de calitriquídeos e a sua etiologia não foi determinada.

A complexidade e importância da SEP motivaram esse estudo e os resultados alcançados descrevem a síndrome do ponto de vista clínico, laboratorial e anatomopatológico, contribuindo de forma original para o esclarecimento e caracterização da história natural desse grave processo.

\section{Adequação dos critérios para seleção da casuística utilizada}

Os sagüis selecionados para compor a casuística desse estudo preencheram todos os critérios de homogeneidade estabelecidos e mostraram adequação para responder as hipóteses formuladas. O rigor utilizado na seleção dos casos foi essencial para formar o corpo de dados 
consistente para ser analisado. Para obedecer aos critérios de inclusão e exclusão foi necessário retirar grande número de animais inicialmente acompanhados no criadouro.

\subsection{Qual o perfil epidemiológico dos sagüis com SEP em nosso meio?}

A SEP acometeu as espécies sagüi-de-tufo-preto, sagüi-de-tufo-branco, sagüi-de-carabranca e híbridos de calitriquídeos mantidos no criadouro Mucky. Na literatura, são descritos quadros de SEP em várias espécies dos seis gêneros da Família Callitrichidae, incluindo as estudadas em nossa casuística (IALLEGIO \& BAKER, 1995; LUSHBAUGH et al., 1985).

O acometimento de SEP nas espécies sagüi-de-tufo-branco (C. jacchus) e sagüi-detopete-branco (Saguinus oedipus) têm destaque na literatura com número maior de relatos, em decorrência de serem as mesmas mais freqüentemente mantidas em laboratórios experimentais para utilização em pesquisas biomédicas (BOYDE, 2003; DINIZ \& daCOSTA, 1995; MITTERMEIER et al., 1994; MANSFIELD, 2003; OWEN, 1996). Desconhecemos estudos apontando predisposição ou diferença de susceptibilidade entre as várias espécies de calitriquídeos acometidos por SEP.

Na nossa casuística não houve predisposição quanto ao sexo. Esse resultado está em concordância com a maioria dos relatos na literatura (BARNARD et a., 1988; CHALIAFOUX et al., 1982; GOZALO \& MONTOYA, 1991; MURGATROYD \& CHALMERS, 1980; LUDLAGE \& MANSFIELD, 2003; SÁ, 1999; SHIMWELL et al., 1979). Contudo, os autores BRACK \& ROTHE (1981) descrevem o predomínio da síndrome em fêmeas pertencentes à colônia de sagüi-de-tufo-branco.

Em nosso estudo, a idade média dos animais com SEP variou de três a seis anos e meio (57,48 $\pm 21,20$ meses), sendo 16 meses a idade mínima de acometimento, devendo-se 
ressaltar, no entanto, que há descrições de SEP em animais com seis meses de idade (LUDLAGE \& MANSFIELD, 2003). Os relatos na literatura não são claros em definir em qual faixa etária predomina a doença. De modo geral, é assumido que a SEP pode ocorrer em sagüis de todas as idades (MURGATROYD \& CHALMERS, 1980; POTKAY, 1992).

Ao nosso ver é significante notar que, apesar da faixa etária de maior freqüência não estar definida, a grande maioria dos animais estudados por nós são adultos com idade por volta de 4 a 6 anos.

Em nossa casuística, a maioria dos sagüis do grupo índice nasceu no cativeiro. $\mathrm{O}$ tempo de permanência no criadouro variou de dois a seis anos e este resultado está em concordância com os dados de literatura, os quais referem animais com SEP que estavam em cativeiro por tempo variável de 18 meses a 8 anos (BEGLINGER et al., 1988; GOZALO \& MONTOYA, 1991; LEWIS et al., 19887; SCULLION et al., 1987; LOGAN \& KHAN, 1996; CLAPP et al., 1993; ABBOTT et al., 2003).

Não são raros os relatos mencionando que determinada colônia mantinha sagüis aparentemente saudáveis e, abruptamente, após o período de cerca de dois anos os animais começaram a adoecer e a morrer com sinais de SEP (BEGLINGER et al., 1988; BRACK \& ROTHE, 1981; LEWIS et al., 1987; LOGAN \& KHAN, 1996). Muito provavelmente esse fato relaciona-se com o tempo de cativeiro desses animais submetidos à mesma dieta e manejo e, possivelmente ao/s mesmo/s estímulo/s antigênico/s. Nesse contexto, CLAPP et al. (1993) e GOZALO \& MONTOYA (1991) claramente associam a gravidade das lesões de colite crônica com o tempo de cativeiro nos calitriquídeos estudados. Esses autores levantaram a possibilidade que a colite observada seria conseqüência de um processo de alergia frente à exposição crônica a antígenos presentes na dieta.

A análise preliminar da genealogia dos sagüis estudados em nossa pesquisa nos sugere predisposição familiar para o desenvolvimento de SEP. Segundo MURGATROYD \& 
CHALMERS (1980) e SHIMWELL et al. (1979), a SEP não tem relação com hereditariedade ou grau de parentesco. Em casos de SEP ocorrendo em sagüis-de-topete-branco estudos preliminares apontam para susceptibilidade familiar (CLAPP et al., 1993). Acreditamos que o mapeamento genético poderia definir uma predisposição familiar nos animais que desenvolvem SEP.

Assim, com base nos nossos resultados e dados de literatura, a SEP acomete calitriquídeos adultos, sem predisposição ao sexo, mantidos por pelo menos 18 meses no cativeiro sob condições estáveis de manejo.

\subsection{A deficiência protéico-calórica é fator desencadeante da enteropatia?}

A dieta oferecida pelo criadouro Mucky é produzida no próprio criadouro e utiliza legumes, frutas, carne branca, ovos e "cereais". A dieta apresenta particularidades quanto à freqüência de cada item usado, mostrando grande variabilidade no decorrer de um ano. Destaca-se que o item "cereal" está entre os três itens mais oferecidos por mês no ano e a avaliação da composição nutricional da dieta efetivamente consumida revelou níveis de proteína bruta e energia metabolizável dentro do recomendável para manutenção de sagüis adultos (NRC 2003).

Para COIMBRA-FILHO \& MAIA (1977) é comum constatar perda de apetite em sagüis mantidos em cativeiro e esse fato pode estar relacionado com monotonia alimentar. Segundo MORIN (1985) vários técnicos concordam que os calitriquídeos requerem variabilidade na fonte de alimentos. Nesse sentido a dieta oferecida no criadouro Mucky está dentro do preconizado para manutenção de calitriquídeos, embora seja uma dieta de difícil análise. 
A dieta usada pelo criadouro Mucky pode ser avaliada não só em relação aos níveis gerais de proteína e caloria, mas de forma indireta com relação aos índices reprodutivos da colônia (dados não mostrados). Os índices avaliados pela relação do número de nascimento/ ano (53 nascimentos em 2000); número de gêmeos (14 gestações gemelares; 7 trigemelar em 2000); intervalo entre partos (variando de 150 a 300 dias) e número de nascimentos por fêmea no ano (em média ocorreram dois nascimentos por fêmea pareada em idade reprodutiva no ano) apresentam resultados adequados e semelhantes aos descritos por PETERS \&GUERRA (1998) ; TARDIF et al. (2003) e LAYNE \& POWER (2003). Desta foram, a colônia de calitriquídeos do Mucky é comparável e semelhante a outras colônias com relação à adequação do manejo geral.

A presença de "cereal” na dieta também é uma variável comum em várias instituições no Brasil, como a descrita no Centro de Primatologia do Rio de Janeiro (CPRJ/ FEEMA); Centro de Biologia da Reprodução da Universidade Federal de Juiz de Fora, Minas Gerais; Parque Zoológico Municipal "Quinzinho de Barros", Sorocaba; Divisão de Medicina Veterinária e Biologia da Fauna, Departamento de Parques e Áreas Verdes da Prefeitura de São Paulo (DEPAVE-3) e Parque Ecológico do Tietê, São Paulo (LEITE, 2002; PETERS \& GUERRA, 1998; SÁ, 1999). No entanto, os produtos que compõe o item “cereal” são diferentes, uma vez que essas instituições utilizam pão e ração comerciais para cães ou primatas (LEITE, 2002; PETERS \& GUERRA, 1998; SÁ, 1999).

Com relação às instituições fora do Brasil, é senso comum utilizar dietas comerciais tais como: ZuPreem marmoset diet (Hills division, Premium Nutritional products, Inc., Mission, Kans); Harlan Teklad New World Primate Diet (HT, Madison, Wisconsin); High protein monkey chow 5045 (Ralston Purina Co., Sta. Louis, MO.) (LAYNE \& POWER, 2003; BARNARD \& KNAPKA, 1993; <http://www.zupreem.com>; <http://www.teklad.com>). Os ingredientes que compõem essas dietas incluem grãos e subprodutos, na maioria de trigo, 
farinha de sementes, farinha de forragens, subprodutos de origem animal entre outros (NRC 2003).

No que tange a uma primeira análise, as dietas têm em comum três fatores: 1- todas parecem ser corretas quanto à manutenção de calitriquídeos com níveis adequados dos índices reprodutivos; 2- presença de "cereais", mesmo considerando que diferem quanto à fonte, qualidade e quantidade, 3- variação na forma de apresentação e composição nutricional.

Segundo BARNARD \& KNAPKA (1993), alimentar primatas não-humanos com dietas comerciais, suplementadas com frutas e complexos vitamínicos é o caminho correto de prevenir deficiências, quando as necessidades nutricionais não estão estabelecidas para a espécie. No NRC (2003) percebemos que as necessidades para calitriquídeos, baseadas nos gêneros Callithrix spp, Saguinus spp e Leontopithecus spp. não estão totalmente definidas e ainda apresentam controvérsia quanto aos níveis de proteínas.

Nos anos 70 e 80, vários autores concordavam que os calitriquídeos necessitavam de aporte protéico elevado baseados na constatação empírica que aumentando o aporte havia melhora da condição do pelame e ganho de peso (COIMBRA-FILHO, 1977; CLAPP \& TARDIF, 1985). Os níveis de proteína sugeridos por alguns autores surpreendem, tais como níveis acima de 25\%. No entanto, no NRC (2003), o nível mínimo recomendável de proteína necessário para manutenção de calitriquídeos adultos é 7\%, variando de 12 a 22\% para fase de crescimento. Constata-se que não está estabelecido qual seria o valor ideal para todas as etapas da vida desses pequenos primatas.

BARNARD et al. (1988) postularam que os calitriquídeos com SEP apresentavam sinais de deficiência protéica-calórica decorrente da má qualidade da dieta e que aumentando os níveis de proteína bruta na base seca de $23,4 \%$ para $26,2 \%$ havia melhora dos animais, inclusive com aumento de consumo da dieta. É preciso considerar que na nova dieta ofertada não foram incluídos itens com cereais, como já foi previamente apontado no NRC (2003). 
Com essa nova dieta ofertada cessaram os episódios de diarréia, ocorreu ganho de peso e melhora do pelame. Parece-nos que a retirada dos cereais da dieta poderia também estar influenciando os resultados relatados. GORE et al., (2001) testaram a retirada do glúten, leite e ovos da deita de animais com SEP e verificaram alteração no quadro clínico-laboratorial dos animais doentes, o que segundo os autores indicaria que a fonte de proteína pode ser mais importante do que a concentração de proteína na dieta. Ainda outros autores relatam que não há alteração na freqüência de episódios de diarréia e/ou de colites com a mudança de dieta (ESCAJADILLO et al., 1981). Porém, para outros a dieta com baixos níveis protéicos ocasiona SEP (FLURER et al., 1983; KIRKWOOD et al., 1983; MORIN 1983).

Vários autores relatam que a SEP está relacionada com deficiência de micronutrientes como zinco, vitamina E, vitamina A e selênio decorrentes de dieta inadequada (BARNARD et al., 1988; BASKIN et al., 1983; CHADWICK et al., 1979; GHEBREMESKEL et al., 1990; GUTTERIDGE et al., 1986; MURGATROYD \& CHALMERS, 1980; JUAN-SALLÉS et al., 2003). No entanto, a suplementação com esses micronutrientes não impede o aparecimento de casos de SEP nas colônias. Alguns outros autores questionam se a deficiência é primária ou secundária a processo de má-absorção (BARNARD et al., 1988; JUAN-SALLÉS, 2003; SÁ, 1999).

$\mathrm{Na}$ dieta do criadouro Mucky, os níveis de vitaminas ou dos minerais individualizados não foram determinados, exceto da matéria mineral como um todo. Os animais acompanhados nesse estudo foram suplementados com complexos minerais e vitamínicos e observou-se melhora temporária dos sintomas, mas não houve desaparecimento ou cura da SEP.

Desta forma, a análise dos nossos resultados mostrou que a dieta ofertada não é deficiente quanto aos parâmetros de proteína e caloria. Essa constatação torna pouco provável a hipóteses de deficiência protéico-calórica como causa primária da SEP. 


\subsection{Como suspeitar de SEP a partir dos sinais clínicos?}

Os principais sinais clínicos observados nos sagüis com SEP foram alterações gastrintestinais crônicas que se caracterizaram por emagrecimento progressivo, diarréia com fezes pastosas, volumosas, intermitentes e distensão abdominal. As lesões foram consideradas crônicas segundo a observação de fezes diarréicas ou pastosas sem forma definida pelo menos duas vezes ao dia durante mais de 30 dias (TAMS, 2003).

Os sinais clínicos observados por nós são semelhantes aos descritas nos casos de SEP na literatura (BRACK \& ROTHE, 1981; CHALMERS et al., 1983; CLAPP et al., 1993; HAWKEY \& HART, 1986; IALEGGIO \& BAKER, 1995; KIRKWOOD et al., 1983; LEITE, 2002; LOGAN \& KHAN, 1996; LUDLAGE \& MANSFIELD, 2003; McNEES et al., 1983; MORIN, 1983; MORIN, 1985; POTKAY, 1992; SÁ, 1999; SAINSBURY et al., 1987).

Inicialmente, de acordo com dados da literatura, a constatação de emagrecimento e alteração de desenvolvimento de sagüis jovens mantidos em cativeiro foi relacionada à dieta incorreta, ao comportamento de competição e dominância entre os indivíduos de um mesmo grupo familiar, à seletividade por alguns alimentos de menor valor nutritivo e ao estresse por não adaptação ao cativeiro (GOZALO \& MONTOYA, 1991; KIRKWOOD et al., 1983; MORIN, 1985; SHIMWEL et al., 1979). Na nossa casuística esses fatores não parecem ter grande relevância no desencadeamento da SEP, pois, os sagüis foram considerados adaptados, visto que o estudo incluiu apenas os casos com pelo menos seis meses de cativeiro sob as mesmas condições de manejo, e ingeriam dieta adequada.

Além disso, os sinais clínicos de diarréia, alteração do aspecto das fezes, associados à distensão abdominal e emagrecimento progressivo apontam para uma enteropatia como comprometimento básico na SEP. 
A observação de fezes aumentadas de volume, pastosas, sem forma ou diarréicas e que são eliminadas de forma intermitente sugerem lesão em intestino delgado, uma vez que diarréia em pequena quantidade e várias vezes ao dia, por vezes com presença de muco ou sangue são geralmente associadas ao comprometimento do intestino grosso (SHERDING, 2003).

Considerando os sinais clínicos exibidos pelos sagüis com SEP aliados às alterações das fezes tem-se indicação de envolvimento do intestino delgado na doença. Destaca-se a relevância da observação das fezes dos sagüis mantidos em cativeiro como parte da inspeção clínica diária do estado de saúde desses animais, uma vez que a alteração das fezes é um dos sinais clínicos da SEP.

A constatação de perda de peso progressiva só é possível mediante a rotina de pesar os sagüis pelo menos uma vez ao mês, levando em consideração sempre o mesmo horário de pesagem e a relação com o peso usual dos outros sagüis da colônia. A avaliação freqüente do peso permitiu detectar precocemente o emagrecimento que precede as alterações das fezes em alguns casos.

Recentemente, tivemos acesso a considerações semelhantes a respeito de procedimentos clínicos e exame físico, preconizado pelos veterinários do New England Primate Research Center, EUA (LUDLAGE \& MANSFIELD, 2003).

Na SEP a alteração de apetite é um comportamento bastante claro, seja por avaliação das sobras de alimentos oferecidos ou pela pesagem do animal em jejum e pesagem ao final da tarde. A seletividade e perda de apetite foram constatadas por nós e por outros autores (SHIMWEL et al., 1979; KIRKWOOD et al., 1983).

A observação clínica de anasarca foi considerada evento tardio e terminal, na maioria das vezes. Esse sinal foi incluído em conjunto com dos sinais gastrintestinais porque acompanhou de recrudescimento dos sinais de emagrecimento e alteração das fezes. 
Provavelmente, a anasarca é decorrente da hipoproteinemia conseqüente a proteinúria e perda protéica pela enteropatia. Outros autores observaram hipoproteinemia nos casos de SEP e a associaram ao aporte deficitário de proteína (McNEES et al., 1983; LOGAN \& KHAN, 1996; SHIMWELL et al., 1979).

Houve acometimento de outros sistemas com sinais extra-intestinais, entre eles mucosas hipocoradas e anemia, coincidindo com relatos de outros autores (BASKIN et al., 1983; BEGLINGER et al., 1988; CHALMERS et al., 1983; GUTTERIDGE et al., 1986; JUAN-SALLÉS, 2003; HAWKEY, 1984; HAWKEY \& HART, 1986; LOGAN \& KHAN, 1996; MORIN, 1983; MORIN, 1985; POTKAY, 1992; SHIMWELL et al., 1979; SÁ, 1999).

A anemia se caracteriza laboratorialmente por ser macrocítica normocrômica cujas alterações morfológicas incluem basofilia das hemácias, presença de corpúsculos de HowellJolly, policromasia, anisocitose, poiquilocitose e presença de corpúsculo de Heinz (LOGAN \& KHAN, 1996). Outros autores descreveram anemia hemolítica com presença de corpúsculo de Heinz, secundária a deficiência de vitamina E na dieta (BASKIN et al., 1983; CHALMERS et al., 1983; GUTTERIDGE et al., 1986; JUAN-SALLÉS, 2003; HAWKEY, 1984; HAWKEY \& HART, 1986).

A nefropatia associada a hipoproteinemia presente na SEP, como causa de morte tem sido objeto de pesquisas de BRACK (1988); BRACK \& WEBER (1995); BRACK et al. (1999) e SCHOROEDER et al. (1999). No presente estudo foram observados casos de SEP, que além do quadro gastrintestinal apresentavam lesões renais glomerulares (dados não mostrados).

As alterações motoras ou neuromotoras foram sinais mais tardios e considerados terminais, e, desta forma, por vezes não foram observados nos casos do óbito precoce. Alterações da marcha também foram descritas por outros autores como BRACK \& ROTHE (1981); BEGLINGER et al. (1988); JUAN-SALLÉS (2003); McNEES et al. (1983); 
MURGATROYD \& CHALMERS (1980); POTKAY (1992) e SÁ (1999). Na nossa casuística foi possível observar lesões precoces do déficit neuromotor, como a perda da sensibilidade proprioceptiva ocorrendo anteriormente a dismetria ou paralisia dos membros posteriores, indicando que as lesões do sistema nervoso periférico e muscular são progressivas e concomitantes. A detecção precoce dessas alterações pode auxiliar no tratamento da SEP, retardando, a progressão da mesma.

Alterações neuro-musculares são descritas nos seres humanos com síndromes de máabsorção relacionadas com deficiência de vitaminas do complexo $\mathrm{B}$, como a vitamina $\mathrm{B}_{12}$, e vitamina A (CRAWFORD, 1999).

As alterações cutâneas, como alopecia da cauda, foram amplamente descritas na literatura (BARNARD et al., 1988; CHADWICK et al., 1979; CHALMERS et al., 1983; IALEGGIO \& BAKER, 1995; McNEES et al., 1983; MORIN, 1983; MURGATROYD \& CHALMERS, 1980; POTKAY, 1992), contudo, nem sempre estão presentes. No nosso estudo houve uma freqüência de $32,5 \%$, sendo, por essa razão, considerada aqui como sinal clínico menor definidor de SEP.

Considerados em conjunto, os sinais clínicos foram divididos em sinais maiores e menores em virtude da freqüência de sua observação. Os sinais da SEP são considerados inespecíficos e por essa razão não é raro os autores questionarem se a SEP é uma única patologia ou uma síndrome comum à várias etiologias (HAWKEY, 1984; HAWKEY \& HART, 1986; LUDLAGE \& MASNFIELD, 2003; POTKAY, 1992). A nosso ver a associação dos sinais clínicos maiores com as menores é indicativa da SEP.

A deficiência primária de proteína e zinco na dieta já foi considerada a causa etiológica dos sinais clínicos observados, como proposto por BARNARD et al. (1988); BRACK \& ROTHE (1981); CHADWICK et al. (1979); KIRKWOOD et al. (1983); MORIN, 1985; SHIMWELL et al. (1979). 
Para nós as alterações de deficiência protéica-calórica observadas na SEP poderiam traduzir um processo de má-absorção. BARNARD et al. (1988) relataram não ser possível afastar essa hipótese em suas investigações.

A hipótese de má-absorção explicaria a observação de melhora temporária dos sinais de SEP, como da anemia e da condição do pelame, quando da suplementação de micronutrientes ao aumento dos níveis de proteína na dieta. Vale aqui ressaltar que a suplementação vitamínica e mineral retarda o inevitável óbito e é somente uma melhora parcial e transitória do ponto de vista clínico.

Os resultados alcançados reforçam a hipótese dos sinais clínicos observados serem manifestações gastrintestinais e extra-intestinais de enteropatia crônica, que ocasiona desnutrição secundária. A persistência e progressão dos sinais clínicos poderiam ser decorrentes da prolongada exposição a antígeno presente na dieta.

\subsection{A avaliação laboratorial das fezes pode contribuir para caracterização da SEP?}

A relevância da avaliação do aspecto das fezes foi anteriormente destacada, devido a possível contribuição no diagnóstico e acompanhamento clínico da saúde de calitriquídeos mantidos em cativeiro.

Destaca-se a diferença significante de eliminação de fezes pastosas e aumentadas de volume, com odor nauseabundo/ fermentativo nos sagüis com SEP em contraposição ao grupo controle. Fezes não formada, pastosa, amarelada e espumosa intermitente foi descrita em sagüis com SEP por outros autores (BRACK \& ROTHE, 1981; KIRKWOOD et al., 1983).

O exame microscópico das fezes revelou presença de gotículas de gordura nas fezes de sagüi com SEP $(p<0,05)$. Esse dado não foi anteriormente demonstrado na literatura e revela 
que as fezes pastosas, amareladas e com odor nauseabundo/ fermentativo são decorrentes da presença de gordura, caracterizando esteatorréia.

Sabe-se que esteatorréia é sinal indicativo de processo de má-absorção (CRAWFORD, 1999; HALL, 1999; LINDLEY \& MACDONALD, 2001; TAMS, 2003). Ressalta-se que a presença de esteatorréia apresenta valor clínico no sentido de ser um indicativo seguro de máabsorção, mas o inverso nem sempre é verdadeiro (GREEMBERGER \& ISSELBBACHER, 1994).

A possibilidade de insuficiência pancreática exócrina como causa da SEP foi investigada em nossa casuística através da pesquisa de tripsina fecal e não houve diferença significativa entre o grupo de doentes e os controles, indicando que as enzimas pancreáticas estavam presentes. Não havendo, portanto, indícios de insuficiência pancreática exócrina. A avaliação de tripsina nas fezes foi conduzida por outros dois autores, que obtiveram resultados semelhantes (BEGLINGER et al., 1988; KIRKWOOD et al., 1983).

A observação de fezes pastosas sem forma e diarréia chamou a atenção de outros pesquisadores que investigaram agentes bacterianos, virais e parasitários (ESTES, 1985; KALISHMAN et al., 1996; KIRKWOOD et al., 1983; LEWIS et al., 1987; MOORE, 1985; RUSSELL et al., 1985; RUSSELL \& BRIAN, 1985; SÁ, 1999). A flora bacteriana de sagüis com SEP se caracteriza por diminuição de lactobacilos e aumento de bactérias anaeróbias como fusobactéria e clostridium, (LEWIS et al., 1987).Talvez, essa alteração da flora pudesse ser decorrente de super-crescimento bacteriano como é relatado em quadros de má-absorção.

Dentre os agentes bacterianos pesquisados por outros autores nas fezes diarréicas destacam-se a presença de Escherichia coli enteropatogênica (EPEC) e Campylobacter spp. (LUDLAGE \& MANSFIELD, 2003; PINHEIRO et al., 1993). Os quadros clínicos de diarréia associados a esses agentes se caracterizam por aspecto e freqüência variáveis de aquosa a hemorrágica e aguda a persistente. Ambas situações se medicadas com antibiótico apresentam 
melhora (LUDLAGE \& MANSFIELD, 2003; PINHEIRO et al., 1993; RUSSELL et al., 1985). Não há associação dessas bactérias como agentes causais de SEP e de colites (LUDLAGE \& MANSFIELD, 2003; RUSSELL et al., 1985).

Outros autores não confirmaram a hipótese de coronavírus estar associado a SEP, mesmo com a identificação de partículas virais assemelhadas a coronavírus nas fezes de animais com colites ou com diarréia (BRIAN \& SCHOCKLEY, 1993; RUSSELL et al., 1985).

Fez parte dos critérios estabelecidos para esse estudo animais com exame coproparasitológico negativo. Contudo, a identificação de parasitas nematóides e protozoários tem sido pesquisada nas fezes de sagüis com SEP. BEGLINGER et al (1988) mostrou a presença de ovos de Trichospirura leptostoma, parasita de ducto pancreático, em 52\% das fezes analisadas de sagüis com SEP. Esses autores associaram insuficiência pancreática decorrente da infestação por nematóides como a causa para SEP na colônia de sagüi-de-tufobranco.

Em levantamento da infestação por Giardia e Cryptosporidium na colônia de sagüide-tufo-branco revelou-se que sagüis mantidos em cativeiro podem carrear esses protozoários em todas as idades, porém a maior porcentagem foi observada em indivíduos jovens com idade inferior a um ano e indicando que a infecção por esses parasitos é autolimitante e, provavelmente, não ocasione prejuízos à saúde de sagüis imunologicamente sãos (KALISHMAN et al., 1996).

Desta forma, o exame macro e microscópico das fezes permitiu mostrar que os sagüis com SEP apresentam esteatorréia intermitente, cujas fezes se caracterizam pela consistência pastosa sem forma definida, volumosa, com odor nauseabundo/ fermentativo e com presença de gotículas de gordura. A observação de esteatorréia é indicativa de processo de má-absorção 
e a presença de tripsina fecal permitiu afastar a hipótese de insuficiência pancreática primária como causa de SEP.

\subsection{Poderia o teste de absorção de D-xilose contribuir para caracterização da má-absorção na SEP?}

A avaliação da função absortiva do intestino delgado não havia sido realizada anteriormente nessas espécies e revelou que todos os sagüis com SEP apresentaram eliminação de D-xilose inferior a $16 \%$ da dose administrada, enquanto os controles eliminaram acima de $16 \%(\mathrm{p}<0,001)$. Esse resultado demonstra que os sagüis com SEP apresentam disfunção da capacidade absortiva do jejuno.

Na literatura, o teste de D-xilose foi aplicado em casos de má-absorção de um macaco rhesus (Macaca mulatta) e um macaco cinomolgus (Macaca fascicularis) e os resultados indicaram anormalidade na mucosa do intestino delgado (HARRIS et al., 1984; WAGNER et al., 1988).

O teste de D-xilose foi um dos testes de escolha para a avaliação da absorção do intestino delgado nos casos de crianças e adultos com suspeita de má-absorção durante várias décadas, e hoje ainda é utilizado apesar das críticas (CRAIG \& ATKINSON, 1988; de FREITAS et al., 2002; SDEPANIAN et al., 1999).

D-xilose é um monossacarídeo que atravessa a barreira intestinal por difusão nos segmentos do duodeno e jejuno, não é metabolizável no fígado e é eliminado na urina (CRAIG \& ATKINSON, 1988). Devido a essas características o teste de D-xilose reflete a capacidade da superfície absortiva da mucosa do jejuno (ROLSTON \& MATHAN, 1989). 
A dose e valor de corte para o teste foram os mesmos utilizados em crianças por HAWKINS (1970). Os autores mostram que há grande controvérsia em relação à eficácia do teste de D-xilose detectar pacientes com má-absorção. Dentre os fatores que poderiam interferir nos resultados e interpretação dos mesmos são citados: tempo de esvaziamento gástrico; função renal; hidratação inadequada, e dificuldade de coletar a urina no período de cinco horas. As críticas são principalmente voltadas para o uso deste teste em crianças, em que a coleta de urina nem sempre pode ser total (HAENEY et al., 1978; SDEPANIAN et al., 1999).

O teste também é criticado quanto à especificidade, uma vez que esse pode ter resultados anormais tanto na doença celíaca, como na intolerância à proteína do leite de vaca, na enteropatia ambiental e outras formas de diarréia (SDEPANIAN et al., 1999). Em cães e gatos apresenta utilização limitada, uma vez que o mecanismo de absorção de D-xilose nos cães não está definido e apresenta indícios da xilose ser metabolizada antes de ser excretada (HALL, 1999).

Autores sugerem a realização de teste de permeabilidade da mucosa com dois açúcares, como lactulose (dissacarídeo) e manitol (monossacarídeo) para diferenciar casos de pacientes humanos com doença celíaca dos indivíduos controles ou com sintomas gastrintestinais inespecíficos (UIL et al., 1997).

No caso dos sagüis, embora tenha sido pela primeira vez aplicado nessa espécie, os resultados foram assertivos em diferenciar sagüis com SEP dos controles. Indicando que esses animais apresentam disfunção da capacidade absortiva no segmento proximal do intestino delgado. 


\subsection{Há alterações na eficiência digestiva nos sagüis com SEP?}

A diferença entre os coeficientes de digestibilidade (DA) foi sete pontos percentuais quanto à digestão da matéria seca dos alimentos entre os grupos dos sagüis com SEP e dos controles, indicando menor capacidade digestiva geral dos sagüis com SEP.

Dentre os nutrientes avaliados, a proteína e matéria mineral foram os nutrientes para os quais os sagüis com SEP tiveram a menor capacidade digestiva $(p<0,05)$. Com relação aos extrativos não nitrogenados, ou seja, aos carboidratos, constata-se tendência à menor digestão $(p=0,07)$.

Quanto ao extrato etéreo, apesar da digestão do grupo dos sagüis com SEP ser menor em 37,5 pontos percentuais em comparação aos controles, a análise estatística indicou apenas tendência à diferença $(\mathrm{p}=0,07)$. A ausência de diferença estatística pode ter sido decorrente da grande variabilidade desta medida, pois o coeficiente de variação dentre os sadios foi de $22,5 \%$ e dentre os sagüis com SEP de 57,3\%. Assim, o conjunto dos dados nos demonstra grande diminuição da capacidade de absorção de gorduras nos animais comprometidos.

Apesar dos sagüis com SEP apresentarem menor eficiência digestiva geral, não houve diferença de consumo de matéria seca em comparação com os sagüis controles, indicando que não ocorreu compensação da perda do aproveitamento do nutriente com um possível aumento do consumo desses.

No NRC (2003) o DA para proteínas está entre 63-88\% para cinco espécies de primatas não-humanos, incluindo o sagüi-de-tufo-branco. Os sagüis com SEP apresentam menor capacidade digestiva para proteínas em comparação ao NRC.

A avaliação da eficiência digestiva de micos com SEP foi abordada por BARNARD et al. (1988), quando avaliou o DA de micos da espécie sagüi-bigodeiro (Saguinus mystax) durante quatro dias utilizando dieta sem trigo. Os resultados dos DA calculados foram 
comparados com DA de macaco rhesus (Macaca mulatta) e concluído que ambos apresentavam eficiência digestiva semelhante. Os valores de DA alcançados por esses autores foram: $85,7 \% \mathrm{MS} ; 85,0 \% \mathrm{~PB} ; 91,5 \% \mathrm{EE}, 90,4 \% \mathrm{ENN}$ e $69,0 \% \mathrm{FB}$.

Comparando tais resultados com os alcançados em nosso estudo percebeu-se que os resultados obtidos no grupo dos sagüis controles foram equivalentes aos apresentados pelos micos com SEP no trabalho de BARNARD e colaboradores (1988). No entanto, com relação aos sagüis com SEP do nosso estudo, os valores obtidos por nós foram menores. Tal diferença poderia ser decorrente da gravidade de acometimento dos animais utilizados no experimento.

$\mathrm{Na}$ literatura são encontrados vários trabalhos avaliando diferentes dietas para calitriquídeos, utilizando análise empírica da eficácia das dietas somente em relação ao peso dos animais, palatabilidade, consumo, redução do número de episódios de diarréia e avaliação histológica do cólon desses animais (ESCAJADILLO et al, 1981; FLURER et al., 1983; TARDIF et al., 1988; WIRTH \& BUSELMAIER, 1982).

A revisão mais recente sobre nutrição de sagüis foi realizada no trabalho de LAYNE \& POWER (2003), onde traçaram comentários sobre dietas para sagüis e micos comercializadas no EUA, partindo por base que essas seriam adequadas para a manutenção e reprodução de sagüis no cativeiro. Contudo, consultando os níveis de garantia e qualidade das dietas fabricadas percebe-se que são informação vagas e aproximadas. Levando a dúvidas sobre a real composição das rações.

Desta forma, o estudo por nós realizado demonstra claramente que os sagüis com SEP apresentam déficit na digestão geral dos nutrientes, com destaque à digestão de proteínas, matéria mineral e extrato etéreo. Ressalta-se a importância da realização desse estudo devido o reduzido número de informações sobre a avaliação nutricional dessas espécies mantidas no cativeiro e na vigência da SEP. 


\subsection{O exame macroscópico contribui para caracterização da SEP?}

O exame necroscópico mostrou que os sagüis com SEP apresentaram emagrecimento (variando de diminuição do tecido adiposo subcutâneo à caquexia), dilatação abdominal com distensão das alças intestinais por conteúdo pastoso amarelado e palidez das mucosas e órgãos.

$\mathrm{Na}$ literatura foram poucos os trabalhos que descrevem os achados macroscópicos do trato gastrintestinal (BEGLINGER et al., 1988; CHALIAFOUX et al., 1982; CHALIAFOUX et al., 1993; GOZALO \& MONTOYA, 1991).

A ausência de tecido adiposo e a redução da massa muscular são indicativos de processo crônico e debilitante, e difere dos quadros infecciosos agudos, que, em geral, preservam os depósitos de tecido adiposo e a musculatura desenvolvida (SÁ, 1999). Entretanto, a dilatação de alças intestinais é comum também a processos infecciosos bacterianos ou parasitários intestinais.

O exame macroscópico nos casos de SEP, não é característico, todavia, possibilita sugerir processos crônicos, debilitantes com comprometimento intestinal, necessitando exame microscópico e, muitas vezes, microbiológico para firmar-se o diagnóstico de SEP. Por outro lado, a associação dos achados necroscópicos com dados clínicos, laboratoriais e epidemiológicos favorece fortemente a caracterização da SEP.

\subsection{O exame histopatológico do intestino delgado é essencial para o diagnóstico da SEP?}

Os sagüis com SEP na nossa casuística apresentaram em 100\% dos casos enterite crônica com redução parcial ou total do comprimento das vilosidades intestinais no segmento 
de jejuno, hiperplasia das criptas e importante infiltrado linfocítico plasmocítico na lâmina própria, com aspecto histológico semelhante à doença celíaca humana.

Os nossos achados microscópicos estão em oposição aos dados de literatura, que unanimemente descrevem e associam a SEP à lesão localizada essencialmente no cólon e representada por colite crônica, na qual são descritos microabscessos de criptas, infiltrado de mononucleares e polimorfonucleares na lâmina própria, diminuição das células caliciformes e atipia celular (BASKIN et al., 1983; CHALIAFOUX et al., 1982; CHALIAFOUX et al., 1993; CHALMERS et al., 1983; GOZALO \& MONTOYA, 1991; JUAN-SALLÉS, 2003; KIRKWOOD et al., 1983; LUSHBAUGH et al., 1985; POTKAY, 1992; SAINSBURY et al., 1987; SCULLION et al., 1987; TUCKER, 1984).

Em poucos casos o comprometimento do intestino delgado foi descrito como infiltrado de mononucleares na lâmina própria e atrofia de vilosidades, porém esses achados sempre foram considerados menores frente às lesões do intestino grosso (CHALMERS et al., 1983; GOZALO \& MONTOYA, 1991; SCULLION et al., 1987; TUCKER, 1983).

LUDLAGE \& MANSFIELD (2003), referindo-se aos trabalhos de BRACK \& ROTHE (1981), CHALIAFOUX et al., (1983) e GORE et al., (2001) postulam ser a SEP uma doença inflamatória intestinal crônica e a consideram como a alteração gastrintestinal mais comum dos sagüis. Esses autores sugerem que o termo SEP não deveria ser utilizado como tal, em razão de que o mesmo parece reunir mais de uma doença acometendo mais de uma espécie de sagüis.

Os autores LUDLAGE \& MANSFIELD (2003) em trabalho de revisão sobre cuidados clínicos e doenças de sagüis-de-tufo-branco definem a doença inflamatória crônica dos sagüis como enterite linfocítica difusa ou segmentar, com atrofia de vilosidades, hiperplasia das criptas e infiltrado linfocítico na lâmina própria. Embora o quadro histológico, descrito por esses autores, seja similar aos nossos achados, os mesmos estão referidos apenas nesse 
trabalho de revisão. Desconhecemos publicações relativas a estudo sistematizado em casuística pré-definida sobre o comprometimento do intestino delgado na SEP. Convém destacar que divulgamos nossos achados preliminares em apresentação oral no encontro anual da American Association of Zoo Veterinarians (AAZV-2002), realizado na cidade de Milwaukee, USA, em 2002 e que teve o resumo dos resultados publicados em seus anais (SÁ, 2002) precedendo àquele trabalho de revisão.

A avaliação semiquantitativa e morfométrica das alterações microscópicas caracterizou em definitivo a morfologia e o padrão histológico da enteropatia observada na SEP. Os parâmetros utilizados relação vilosidade/ cripta, hiperplasia das criptas, intensidade do infiltrado inflamatório mononuclear na lâmina própria e densidade de linfócitos intraepiteliais foram significantemente diferentes dos animais controles. Julgamos que esses parâmetros podem ser utilizados para diferenciar a SEP de outras enteropatias.

A análise morfométrica do jejuno possibilitou mostrar que houve redução da densidade de área dos vilos, aumento da densidade de área de criptas e aumento da área de lâmina própria, porém com a manutenção da espessura da mucosa, em relação aos controles. De posse desses dados, podemos afirmar que a enteropatia da SEP se caracteriza, quantitativamente, por redução do comprimento das vilosidades, hiperplasia das criptas e expansão da lâmina própria por infiltrado inflamatório.

A associação dos resultados clínicos, laboratoriais e histológicos permitiu-nos caracterizar a SEP como processo de má-absorção, decorrente de grave enterite crônica com redução da superfície de absorção intestinal levando a desnutrição secundária à grave lesão da mucosa.

Devemos ter em mente que o trato gastrintestinal apresenta um número limitado de respostas aos diferentes antígenos e em conseqüência, agentes diferentes podem produzir reação histopatológica similar, porém com manifestações clínicas heterogêneas, na 
dependência da idade e carga genética individual (PEÑA \& CRUSIUS, 1998). É preciso ser enfatizado que o diagnóstico preciso das desordens de má-absorção é dependente da avaliação histopatológica (YARDLEY, 1992), situação que nos leva a indicar para os sagüis com SEP os mesmos procedimentos utilizados para o diagnóstico no homem.

Fazendo um paralelo com dados relatados na literatura vistos em outras espécies, o padrão histológico de lesão da SEP foi semelhante ao descrito em caso de má-absorção e diarréia crônica no gorila (Gorilla gorilla) (MOLTENI et al. 1980), ao caso de má-absorção com atrofia vilar, em macaco rhesus (Macaca mulatta) (HARRIS et al., 1984), e a enteropatia glúten induzida do macaco cinomolgus (Macaca fascicularis) (WAGNER et al., 1988). Atrofia parcial das vilosidades e aumento do infiltrado inflamatório na lâmina própria em sagüis com SEP se assemelham à enterite crônica linfopalsmocitária, descrita em cães (JERGENS et al., 1992; MARKS, 1998; TAMS, 1987, TAMS, 2003).

A doença celíaca (DC) humana clássica foi descrita por Samuel Gee em 1888 e a associação dos efeitos danosos da ingestão de certos cereais à DC remonta do final de 1940, durante o período da Segunda Guerra Mundial (SDEPANIAN et al., 1999). A DC é uma condição inflamatória gastrintestinal induzida por intolerância ao glúten, caracterizada por má-absorção, decorrente de atrofia total ou parcial da mucosa do intestino delgado proximal em indivíduos geneticamente susceptíveis (AMERICAN GASTROENTEROLOGICAL ASSOCIATION, 2001; MAKI \& COLLIN, 1997; SDEPANIAN et al., 1999).

Para o diagnóstico de DC é essencial a biópsia do intestino delgado, com a qual são demonstradas as alterações características, mas não específicas, de: atrofia das vilosidades, redução da relação vilo/ cripta, diminuição da altura dos enterócitos superficiais, aumento do infiltrado de linfócitos e plasmócitos, aumento do número de linfócitos intra-epiteliais e hiperplasia das criptas intestinais (AMERICAN GASTROENTEROLOGICAL 
ASSOCIATION, 2001; de FREITAS et al., 2002; FARREL, \& KELLY, 2002; MAKI \& COLLIN, 1997; SDEPANIAN et al., 1999).

A DC é também denominada de enteropatia sensível ao glúten ou espru celíaco e apresenta prevalência de 1:120 a 1:300 indivíduos na Europa e 1: 3000 indivíduos nos EUA (AMERICAN GASTROENTEROLOGICAL ASSOCIATION, 2001; FARRELL \& KELLY, 2002; JENNINGS \&HOWDLE, 2001). Para alguns autores a DC continua mal diagnosticada e provavelmente mais prevalente do que se acreditava (JENNINGS \& HOWDLE, 2001; MOODIE \& CICLITIRA, 2002).

A doença pode ocorrer em qualquer idade, pode comprometer vários membros de uma mesma família e se caracteriza por amplo espectro de manifestações clínicas gastrintestinais e extra-intestinais (FARRELL \& KELLY, 2002). O conceito de "iceberg celíaco" foi introduzido em 1997, no qual a maioria dos indivíduos passaria a vida em situação assintomática com as chamadas DC silenciosa, com morfologia intestinal característica na ausência de sintomatologia, ou DC latente. (MAKI \& COLLIN, 1997).

A etiopatogenia da DC envolve a ingestão de glúten, susceptibilidade genética, resposta imunológica e outros fatores ambientais, como a infecção por adenovírus (SDEPANIAN et al., 1999).

O glúten é uma proteína presente no trigo, centeio e cevada. Os fragmentos polipeptídicos do glúten solúveis em álcool, que representam $50 \%$ da quantidade total de glúten, são denominados de prolaminas. Estas diferem de acordo com o tipo de cereal, ou seja: gliadina no trigo, secalina no centeio e hordeína na cevada (SDEPANIAN et al., 1999). O efeito deletério da gliadina e secalina está comprovado na DC, contudo o mecanismo de ação não está completamente esclarecido (FARRELL \& KELLY, 2002; JENNINGS \& HOWDLE, 2001). 
O diagnóstico de DC se baseia na associação dos achados clínicos, laboratoriais teste de permeabilidade intestinal usando dissacarídeo/ oligossacarídeo, hematologia, bioquímica sérica e quantificação da gordura nas fezes entre outros-, testes sorológicos (anticorpos IgA e IgG anti-endomísio, IgA e IgG anti transglutaminase tecidual, IgA e IgG anti-gliadina), avaliação histopatológica da biópsia intestinal e melhora clínica e histológica do jejuno após a retirada do glúten da dieta (de FREITAS et al., 2002; JENNINGS \& HOWDLE, 2001; FARRELL \& KELLY, 2002; MAKI \& COLLIN, 1997; MOODIE \& CICLITIRA, 2002; PETRAS, 1994).

As características gerais clínicas, laboratoriais e histopatológicas da SEP são semelhantes à DC, o que nos leva a considerar a SEP uma doença celíaca- "like". A presença de "cereais" na dieta dos sagüis do criadouro Mucky, bem como de outras instituições, favorece a hipótese da SEP apresentar patogenia similar a DC. Alguns autores demonstraram a presença de anticorpos IgA anti-gliadina no soro de sagüis com SEP (GORE et al., 2001; SCHROEDER et al., 1999). Atualmente, somente um autor relata sucesso na utilização de "biscoitos sem glúten" no tratamento de sagüis com SEP (CROOK, 1989). Porém, o relato é superficial e não nos fornece dados conclusivos com relação à utilização de "biscoitos livres de glúten” na melhora clínica de sagüis com SEP.

Em estudo preliminar conduzido por nós, foi retirado o glúten da dieta do criadouro Mucky durante 18 meses, com o objetivo de avaliar os possíveis benefícios da exclusão do glúten aos animais com SEP. Na avaliação preliminar dos resultados constatamos que os animais doentes apresentaram melhora do estado geral, diminuição dos episódios de diarréia e, no exame histológico do jejuno, observamos recuperação do tamanho das vilosidades.

Considerando o padrão de lesão da SEP, tipo doença celíaca-like e comparando-o com outras enteropatias humanas, os diagnósticos diferenciais possíveis seriam: espru refratário, enteropatias associadas à ingestão de outras proteínas, enteropatia auto-imune, deficiência de 
ácido fólico e vitamina B12, marasmo e kwashiorkor, infestação por parasitas, espru tropical e gastrenterite infecciosa.

O espru refratário ou não classificado não apresenta uma definição específica e é considerado uma síndrome pouco esclarecida, em que há má-absorção e presença de severo infiltrado inflamatório na lâmina própria, hiperplasia das criptas e atrofia parcial das vilosidades na vigência de dieta sem glúten (MULDER et al., 2000). Estes casos podem responder ao uso de corticosteróide (GOGGINGS et al., 1994; PETRAS, 1994).

Dentre outras, as injúrias induzidas no intestino delgado por nutrientes devem ser incluídas: enteropatia devido à ingestão de proteína de leite de vaca, enteropatia induzida por carne de frango, por soja e por ovos (GOGGINS et al., 1994; PETRAS, 1994). Essas entidades são consideradas raras, mas exibem quadro morfológico similar à DC (PETRAS, 1994). A patogenia está relacionada com quebra dos mecanismos imunes da tolerância oral. O diagnóstico definitivo daquelas injúrias depende da identificação da proteína desencadeante, demonstração da melhora após a retirada desta da dieta e piora, clínica e histopatológica, com a reintrodução da mesma (LINDLAY \& MACDONALD, 2001).

A enteropatia auto-imune é uma doença rara de caráter familiar e é definida na presença de quatro características: 1- diarréia intratável e severa enteropatia; 2- ausência de resposta com a utilização de nutrição parenteral; 3- presença de auto-anticorpos circulantes e/ ou de doença auto-imune, e 4- ausência de imunodeficiência (LACHAUX et al., 1998). Os indivíduos geralmente são crianças e manifestam doenças auto-imunes tais como artrite reumatóide, diabetes juvenil e anemia hemolítica. As alterações da mucosa intestinal são severas e lembram as observadas na DC e na SEP: atrofia completa das vilosidades do duodeno ao íleo, denso infiltrado inflamatório linfocítico da lâmina própria do trato gastrintestinal, incluindo do estômago, podem ocorrer micro-ulcerações e micro-abscessos. Podem estar presentes macrófagos, plasmócitos e eosinófilos na lâmina própria. A observação 
de hiperplasia das criptas e aumento dos linfócitos intra-epiteliais também pode ocorrer. Exceto, por menor número de linfócitos intraepiteliais em comparação à DC. (LACHAUX et al., 1998; PETRAS, 1994).

Com os dados atualmente disponíveis não é possível afastar totalmente a enteropatia auto-imune como causa da SEP.

Os indivíduos desnutridos devido a marasmo podem apresentar a biópsia intestinal normal ou com áreas segmentares de atrofia vilar associada a reduzido número de mitoses das criptas. Enquanto, nos casos de kwashiorkor há relatos de alteração intestinal semelhante à DC, ou seja, atrofia de vilosidades e aumento do número de linfócitos intraepiteliais. Entretanto, o número de mitoses nas criptas está diminuído (PETRAS, 1994). Os dados comprovados de dieta adequada afastam tais hipóteses.

Dentre os parasitas que podem acometer o trato intestinal e causar má-absorção destaca-se o parasitismo por Giardia spp que pode ser afastada nos casos de SEP por nós estudados porque a sua identificação nos exames de fezes ou no tecido representou um dos critérios absolutos de exclusão da casuística.

Diarréia persistente após o quadro de gastrenterite aguda é denominada de espru tropical ou espru pós-infecção ou enteropatia pós-enterite. Esse quadro está relacionado com a infecção persistente do agente, como Escherichia coli enteropatogênica; ou por infecção secundária, como nos casos de supercrescimento bacteriano, ou pela sensibilização alimentar adquirida secundária à infecção (LINDLEY \& MACDONALD, 2001). A patogênese não está estabelecida e a manifestação clínica pode se caracterizar por má-absorção com esteatorréia. Em algumas situações relaciona-se a pacientes humanos que estiveram por curto período de tempo em áreas subdesenvolvidas (CRAWFORD, 1999). A biópsia do intestino delgado é indicada e mostra alteração variável das vilosidades, porém usualmente se observa discreta a 
moderada atrofia das vilosidades, aumento do infiltrado inflamatório mononuclear na lâmina própria, sem hiperplasia das criptas. (PETRAS, 1994; CRAWFORD, 1999).

As gastrenterites infecciosas ocasionando lesão da mucosa intestinal podem cursar com atrofia da mucosa, porém não na intensidade da DC. Há aumento das células inflamatórias na lâmina própria, composto tanto de mononucleares, como neutrófilos. A natureza aguda e temporária dos sintomas e as alterações agudas observadas na biópsia permitem realizar o diagnóstico diferencial com a SEP e a DC (PETRAS, 1994).

Frente ao que foi exposto e discutido podemos afirmar que a SEP é definida como processo de má-absorção, com características histopatológicas particulares e semelhantes à DC. O exame anatomopatológico do intestino delgado e a correlação com os dados clínicos e laboratoriais são fundamentais para a caracterização da SEP.

A observação unânime de colite com características não específicas nos casos de SEP já descritos na literatura, aliado ao reconhecimento do sagüi-de-topete como modelo experimental para colite ulcerativa e câncer de cólon humano, nos faz traçar as seguintes considerações:

1- seriam a colite do sagüi-de-topete-branco e a enterite por nós observada duas doenças completamente diferentes quanto à história natural, patogenia e morfologia?

2- teria a lesão do intestino delgado sido subestimada frente aos achados de colite?

3- seria a colite apenas extensão da lesão do intestino delgado?

A avaliação futura e detalhada dos fragmentos de cólon dos animais aqui estudados, bem como do delgado de sagüis com SEP em outras instituições poderão auxiliar no esclarecimento dessas considerações. 


\subsection{Validação do método imuno-histoquímico no estudo da resposta imune da enteropatia de sagüis com SEP}

Os mecanismos regulatórios do desenvolvimento e expressão da resposta imune tem sido primeiramente baseados em estudos conduzidos no homem e nos roedores e os resultados obtidos em outras espécies são interpretados no contexto dos achados das primeiras (DAVIS \& HAMILTON, 1998). A validade da interpretação baseia-se em assumir primeiramente que o sistema imune é o mesmo em diferentes espécies de mamíferos e, portanto, os mecanismos envolvidos na resposta imune devem ser idênticos (Davis \& Hamilton, 1998). Estudos comparados demonstraram que os sistemas imunes são similares em várias espécies, mas não idênticos.

Estudos anteriores demonstraram que anticorpos monoclonais humanos antilinfócitos T, antilinfócitos B, anti-T CD4 e anti-T CD8 poderiam ser usados no estudo dos fenótipos de células inflamatórias do sangue periférico de sagüi-de-tufo-branco, bem como no estudo experimental das propriedades funcionais de linfócitos T e B de sagüi-de-tufo-branco sob estímulo de interleucinas humanas IL2 e IL4 (NEUBERT et al., 1996; O'NEILL \& LEVY, 1986; QUINT et al., 1990; SCHOOLEY et al., 1983; WYKRZYKOWSKA et al., 1996).

A utilização de anticorpos monoclonais ou policlonais humanos em material de sagüis, tais como anti-CD20, antiproteína S100, anti-CD3, anti-CD45RO, anti-citoqueratina, entre outros, foram anteriormente demonstrado como tendo validade nos trabalhos de EPIPHANIO, (2001); LEITE (2002) e SÁ (1999).

A padronização da utilização de anticorpos policlonais humanos anticitocinas em material parafinado de sagüis foi realizada no Laboratório da Disciplina de Patologia de Moléstias Transmissíveis, da Faculdade de Medicina da USP. Os procedimentos foram os 
mesmos adotados e conduzidos em trabalhos humanos anteriores com excelentes resultados (QUARESMA, 2003).

O estudo da resposta imune no próprio órgão alvo tem-se mostrado fundamental para caracterização da patogenia e entendimento dos mecanismos regulatórios que regem o padrão de resposta tecidual frente à interação entre componentes do sistema imune e os antígenos desencadeantes. Em especial, destaca-se a resposta imune intestinal como elemento fundamental para manutenção da homeostasia sistêmica.

Uma vez feita a validação da utilização de anticorpos humanos com resultados positivos nos sagüis, pudemos dispor dessa ferramenta para caracterizar a resposta imune no jejuno de sagüis com SEP.

\subsection{A caracterização da resposta imune intestinal pode contribuir para a patogenia e caracterização da SEP?}

A imunomarcação para caracterização do fenótipo das células inflamatórias mostrou primeiramente que existe população heterogênea de linfócitos, macrófagos e células dendríticas presentes na lâmina própria do intestino de sagüis com SEP. Com análise quantitativa caracterizamos aumento de células LT-CD45RO, CD68+, LT-CD8+ e LT-CD4+ e LB-CD20+ nos casos de SEP, em comparação aos controles. Quanto à expressão de citocinas, verificamos o predomínio de citocinas pró-inflamatórias (IL2 e surgimento de expressão de TNF- $\alpha$ e IFN- $\gamma$ ). Não houve diferença estatística significante quanto à expressão de IL4, embora tenha ocorrido aumento da expressão nos sagüis com SEP. 
Demonstramos, desta forma, que a enteropatia da SEP se caracteriza por ativação de linfócitos TCD4+ e expressão de citocinas pró-inflamatórias (perfil TH1) definindo a participação da resposta imune medida por células no desenvolvimento da lesão.

No nosso entendimento esse é o primeiro estudo da resposta imune local de enteropatia apresentada $^{3}-$ E`P agüis.

Segundo o conhecimento já estabelecido um antígeno apresentado, na dependência de suas características e de fatores relacionados com o hospedeiro, poderá induzir o estado de tolerância, ou iniciar a cascata de eventos que levam ao processo inflamatório (GARSIDE \& MOWAT, 1997). Na SEP, com base nos nossos resultados, podemos supor que a interação entre o antígeno da dieta e a resposta do hospedeiro culminou no desenvolvimento de grave enterite.

O padrão morfológico da lesão intestinal e a resposta imune mediada por células caracterizados na SEP mostram similaridades interessantes entre a SEP e a DC humana. O conjunto dessas semelhanças possibilita inferir que a SEP talvez apresente a mesma patogenia da DC.

Cães jovens da raça Setter irlandês desenvolvem enteropatia induzida por glúten, na qual os animais apresentam as mesmas características morfológicas da DC e da SEP. HALL \& BATT, 1990a; HALL \& BATT, 1990b demonstraram que a população de linfócitos presentes na lâmina própria difere dos controles e sugerem resposta imune mediada por células na patogenia da doença.

A DC é o protótipo das enteropatia imunologicamente mediada, caracterizada por atrofia de vilosidades e má-absorção por perda de superfície absortiva decorrente da resposta imune a um único antígeno. Os mecanismos imunes descritos na DC são extrapolados para explicar os mecanismos envolvidos em outras enteropatias induzidas por proteínas presentes na dieta (STROBER \& FUSS, 1999). 
Nesse contexto, podemos interpretar a resposta imune da SEP superpondo-se aos achados já conhecidos na DC. A lesão da DC se inicia com eventos relacionados à produção e liberação de mediadores químicos por mastócitos e neutrófilos, como leucotrieno, prostaglandina $E_{2}$ e ativação do complemento, que levam a aumento da permeabilidade vascular, edema e extravasamento de fibrinogênio na fase aguda da doença. Na SEP as características observadas são de processo crônico, semelhante à lesão clássica da DC, na qual observa-se infiltrado de linfócitos B, T e macrófagos (STROBER \& FUSS, 1999).

As células B e plasmócitos estão relacionados com a produção de $\operatorname{IgA}$, IgG e IgM. A ausência de IgE diferencia a DC de hipersensibilidades alérgicas (STROBER \& FUSS, 1999). Na SEP, observamos a presença de linfócitos B CD20+ aumentados em número, mas sem diferença significante $(\mathrm{p}=0,07)$ com relação aos controles. A participação de células B e o estudo das imunoglobulinas produzidas pelos plasmócitos poderão diferenciar a SEP de processos alérgicos. Na DC os autores postulam que esses plasmócitos e linfócitos B estariam envolvidos na produção de auto-anticorpos e anticorpos anti-gliadina, mostrando a resposta humoral na DC (STROBER \& FUSS, 1999).

Na DC o infiltrado de linfócitos T está presente tanto na lâmina própria, como no compartimento epitelial e constitui populações mistas de LT-CD4+ e LT-CD8+. Uma grande parte das células T mostra marcadores de maturidade celular ou de ativação prévia (células de memória - TCD45RO+), e marcadores de ativação celular, como receptores para IL2 (CD25), mostrando ambiente de reativação imunológica. Os linfócitos intra-epiteliais constituem células CD8+, que estão aumentadas em número e nestes há expressão de CD45RO e marcadores de proliferação celular diferentemente das células $\mathrm{T}$ da lâmina própria (STROBER \& FUSS, 1999).

Na SEP, também observamos aumento da expressão de TCD45RO e linfócitos TCD4+ e TCD8+ na lâmina própria. Embora os sagüis com SEP apresentem densidade de linfócitos 
intra-epiteliais aumentada em relação aos controles, não foi realizado estudo em separado para essas células. No nosso estudo não mostramos a expressão de CD25, mas há o predomínio de IL2, como fator de estímulo para proliferação de clones de linfócitos T e B entre outras células (GÓMEZ et al., 1998).

Os macrófagos e células dendríticas também compõem o infiltrado inflamatório da DC e da SEP. Observamos expressão de CD68 e proteína S100 na mucosa do jejuno. Na DC essas células expressam marcadores de ativação, como expressão de HLA-DR, molécula de adesão intercelular (ICAM-1), B7 e receptor para IL2 (STROBER \& FUSS, 1999). O estímulo para ativação de macrófagos pode ser via própria gliadina ou via células T CD4+ ativadas e secretando TNF- $\alpha$ que ativaria os macrófagos e células dendríticas, que passariam a expressar HLA-DQ (STROBER \& FUSS, 1999).

Na SEP, observamos aumento do número de células CD68+ e expressão de TNF- $\alpha$. O estudo da expressão de moléculas como HLA-DQ, poderia auxiliar no esclarecimento da participação de macrófagos e células dendríticas na SEP.

A imunomarcação para proteína $\mathrm{S} 100$ revelou um número, acima do esperado de células positivas tanto no material dos controles como dos sagüis com SEP. O papel fisiológico dessas células apresentadoras de antígeno ainda na está completamente elucidado, mas são células consideradas células acessórias que estariam envolvidas na degradação de imune complexos em áreas, onde ocorre apresentação de antígenos e deposição de imunecomplexos via ativação da cascata do complemento (SARSFIELD et al., 1996). A análise da distribuição das células $\mathrm{S} 100+$ na lâmina própria de sagüis controles e com SEP, talvez possibilite inferências na função e participação nos processos inflamatórios intestinais desses animais.

No ambiente inflamatório da DC, os enterócitos participam na apresentação de antígenos via expressão de MHC-DR, DQ e DP via estímulo IFN- $\gamma$, secretados por linfócitos 
intra-epiteliais e linfócitos TCD4+ ativados na lâmina própria (STROBER \& FUSS, 1999). O estudo de expressão de MHC tanto nos enterócitos como nas demais células apresentadoras de antígeno, talvez permitisse desvendar o papel dessas células na patogenia da SEP. A presença de IFN- $\gamma$ na lâmina própria de sagüis com SEP, talvez possa estar desempenhando função semelhante a observada na DC.

Na DC a resposta imune a gliadina envolve em parte a participação do sistema imune inato e, em parte a resposta imune adquirida humoral e mediada por células.

O ponto de partida da resposta imune no GALT é o processamento e a apresentação do antígeno na mucosa intestinal. Os estudos dos últimos anos sobre a patogenia da DC se concentraram no esclarecimento da apresentação da gliadina ao linfócito T. Recentemente, foi demonstrada a participação de enzimas pancreáticas, gástricas, peptidases da borda em escova de enterócitos e transglutaminases teciduais na apresentação dos antígenos de gliadina aos linfócitos $\mathrm{T}$, além da importância da caracterização molecular dos epítopos presentes na gliadina (MOWAT, 2003; REIF \& LERNER, 2004). A identificação de transglutaminases teciduais participando na resposta imune da SEP seria uma grande contribuição no esclarecimento da patogenia da síndrome.

Na DC, os estudos estão voltados para a molécula da gliadina e têm sido ressaltados avanços relacionadas à ação das enzimas pancreáticas e gástricas sobre a gliadina produzindo peptídeo mer-33, rico em prolinas e glutaminas, importantes componentes para o reconhecimento desses epítopos pelos linfócitos T. O peptídeo mer-33 apresenta elevada especificidade pelas tTG, que promove a deaminação do aminoácido glutamina em ácido glutâmico levando a exposição de carga negativa e a ligação na molécula de HLA-DQ2 presentes nas células T e células dendríticas (SHAN et al., 2002; MOWAT, 2003). O peptídeo mer-33 é absorvido intacto via transporte transcelular ou paracelular até a lâmina própria do 
intestino (MOWAT, 2003). O detalhamento da complexidade da resposta imune a gliadina motiva a busca por respostas semelhantes na SEP.

SHAN e colaboradores (2003) também demonstraram apenas homologia entre a molécula do peptídeo mer-33 com o trigo, a cevada e o centeio, que sabidamente induzem DC, mas não mostraram no arroz, aveia ou milho. Fica assim claramente demonstrado que a ligação gliadina-linfócito $\mathrm{T}$ é condição suficiente para iniciação e manutenção da resposta imune, via tTG. Essas considerações não explicam o componente de auto-imune da DC.

O modelo descrito para explicar a razão da produção de auto anticorpos anti- tTG se baseia na demonstração da capacidade de apresentação de antígenos pelos linfócitos B via HLA-DQ2. Clones de linfócitos B apresentariam a linfócitos T CD4+ peptídeos de gliadina ou tTG ou epítopos em comum, via receptores HLA-DQ2. Os linfócitos TCD4+, sob os mesmos estímulos, promoveriam, via secreção de IL4, a proliferação de clones de linfócitos B auto-reativos e em conseqüência ocorreria a produção de auto-anticorpos anti-gliadina, antitTG e anti complexo tTG-gliadina (SCHUPPAN, 2000; SOLLID, 1997).

Os linfócitos $\mathrm{T}$ uma vez ativados passariam a secretar citocinas como IL2, que promoveria a expansão clonal de linfócitos $\mathrm{T}$ ativados, linfócitos $\mathrm{B}$ e células assassinas naturais $(\mathrm{NK})$, envolvidas tanto na resposta humoral como mediada por células (GÓMEZ et al., 1998).

Na resposta imune da SEP, a expressão de IL2 e de células TCD4+ e TCD8+ foi significantemente maior do que os controles, mostrando que essa citocina está participando ativamente da resposta imune estimulando a proliferação das células inflamatórias mononucleares. Os linfócitos $\mathrm{B}$ CD20+ também compareceram em número elevado em relação aos controles, embora sem diferença significante. Nesse sentido, o número elevado de linfócitos CD20 poderia estar relacionado com maior produção de anticorpos, e mesmo autoanticorpos à semelhança da doença celíaca? Estudos posteriores da expressão de IgA ou 
pesquisas no sangue periférico de auto-anticorpos poderão auxiliar na resposta dessa pergunta.

As lesões histopatológicas observadas na DC resultam de alterações graduais a partir da mucosa normal até a atrofia das vilosidades e hiperplasia das criptas (GUANDALINI \& GOKHALE, 2002). Acreditamos que processo semelhante ocorra na SEP, uma vez que observamos diferentes graus de comprometimento da mucosa nos casos estudados.

Diferentes hipóteses de mecanismos envolvendo citocinas têm sido discutidas para mostrar a ligação entre a ativação de linfócitos T CD4+ e a transformação da mucosa na DC. Esses mecanismos poderiam estar, também, envolvidos na SEP.

SCHUPPAN (2000) em trabalho de revisão descreve que células T CD4+, com perfil TH1 secretariam TNF, o qual provoca a liberação de metaloproteinases da matriz extracelular (MMPs) por fibroblastos da lâmina própria. As enzimas MMPs degradariam as fibras colágenas, bem como, os demais componentes da matriz extracelular levando a atrofia da mucosa. Nesse ambiente inflamatório, os fibroblastos e outras células mononucleares atuam, também, como fontes de tTG, que realimentariam o processo. Acrescenta-se que os fibroblastos ativados produzem fatores de crescimento de queratinócitos (KGF) levando a hiperplasia das criptas na DC.

A liberação de INF- $\gamma$ por linfócitos com padrão de secreção de citocinas TH1 também estaria associada com a atrofia de vilosidades e hiperplasia de criptas (MOWAT, 2003). A atrofia das vilosidades pode ocorrer via apoptose com a expressão de receptores de Fas nos enterócitos (MAIURI et al, 2001). Estudos recentes in vitro demonstraram envolvimento da IL15 (produzida por monócitos e por células epiteliais) estariam contribuindo para a hiperplasia de criptas, migração dos linfócitos intraepiteliais e apoptose de enterócitos (MAURI et al., 2000). 
Apesar das várias hipóteses levantadas, e dos estudos aprofundados a patogenia da DC ainda suscita comprovações in vivo e esclarecimentos sobre a interação entre genética, ambiente e processamento intestinal de proteínas.(MOWAT, 2003).

Na SEP, frente a tudo que foi exposto, podemos perceber a dimensão do quanto ainda falta para esclarecer a razão da quebra da homeostasia e o desenvolvimento de resposta inflamatória intestinal que leva ao grave processo de má-absorção, mediado por células imunes. O quadro 1 apresenta com base nos nossos resultados e correlação com os dados da literatura o nosso entendimento atual sobre a patogenia da SEP.

Acreditamos que na SEP a quebra da homeostasia e a não tolerância oral provavelmente estaria relacionada com a natureza do antígeno envolvido, com o ambiente do cativeiro que propicia a exposição, e com as características genéticas e imunológicas desses pequenos primatas. Tais fatores levariam à alteração da seleção natural já bem estabelecida para as espécies em ambiente de vida livre. O resultado da seleção provocada pelo homem apresenta, no primeiro instante, elevada morbidade e mortalidade de calitriquídeos, mas quais seriam os efeitos em longo prazo? 


\section{CONCLUSÕES}

Diante do exposto, podemos concluir que:

1. A SEP em nosso meio acomete calitriquídeos de diferentes espécies, adultos, de ambos os sexos, mantidos em cativeiro sob condições estáveis de manejo por pelo menos 18 meses reproduzindo o perfil descrito em outros centros de investigação.

2. A partir da análise da composição da dieta oferecida e efetivamente consumida, que mostrou parâmetros de proteína e energia adequados, pode-se afastar a hipótese de deficiência protéico-calórica como causa primária da SEP.

3. A categorização dos sinais clínicos de SEP em maiores e menores, segundo a freqüência de sua ocorrência, representa ferramenta auxiliar que deve ser usada para o diagnóstico clínico da síndrome.

4. A identificação de esteatorréia representa sinal importante, indicativo de máabsorção e reflete possivelmente o comprometimento da função absortiva do intestino delgado na SEP.

5. A verificação de atividade de tripsina nas fezes permitiu afastar a hipótese de comprometimento primário do pâncreas exócrino como causa de má-absorção na SEP.

6. Nos sagüis com SEP o teste de D-xilose, utilizando-se valores de referência humanos, mostrou-se útil para avaliar laboratorialmente o comprometimento da função absortiva do Intestino delgado, sendo capaz de diferenciar os sagüis com SEP daqueles controles sadios. 
7. Os sagüis com SEP apresentam comprometimento na digestão e absorção de proteínas, gorduras e minerais quando avaliados quanto a digestibilidade da dieta oferecida em relação ao grupo controle.

8. A SEP é uma enterite crônica com atrofia parcial ou total das vilosidades, hiperplasia das criptas, importante infiltrado linfoplasmocitário da lâmina própria, aumento da densidade de linfócitos intra-epiteliais, cujo aspecto morfológico é superponível à doença celíaca humana, o que sugere patogenia comum para os dois processos.

9. A resposta imune local na enteropatia da SEP se caracteriza por aumento de células inflamatórias com fenótipo $\mathrm{CD} 45 \mathrm{RO}+, \mathrm{CD} 68+, \mathrm{CD} 4+, \mathrm{CD} 8+$ e ambiente de citocinas pró-inflamatórias com predomínio de IL2 e expressão de TNF- $\alpha$, IFN- $\gamma$ e IL4. O fenótipo das células inflamatórias no ambiente de citocinas é indicativo de resposta de tipo TH1, caracterizando enteropatia imunomediada, semelhante à doença celíaca humana.

A associação dos resultados clínicos, laboratoriais e histológicos permite definir a SEP como processo de má-absorção, por perda de superfície absortiva, decorrente de enterite crônica imunomediada de padrão celíaco-like que leva a progressiva e grave desnutrição secundária. 


\section{REFERÊNCIAS}

ABBOTT, D. H.; BARNETT, D. K.; COLMAN, R. J.; YAMAMOTO, M. E.; DARKENSCHLTZ, N. J. Aspects of common marmoset basic biology and life history important for biomedical research. Comparative medicine, v.53, n. 4, p. 339-350, 2003.

ALENCAR, A. L.; OLIVEIRA, M. S.; LOPES, F. A.; SOUSA, M. B. C.; SILVA, N. G. Behaviour and progesterone levels in Callithrix jacchus females. Brazilian Journal of Medical and Biological Research, v. 28, p. 591-595, 1995.

AMERICAN GASTROENTEROLOGICAL ASSOCIATION (AGA). Celiac sprue. Gastroenterology, v. 120, p. 1522-1525, 2001.

ANTUNES, S. G.; et al. The common marmoset: a new world primate species with limited MHC class II variability. Proceedings National Academic Science, v. 95, n.20, p. 11745$11750,1998$.

ARRUDA, M. F.; YAMAMOTO, M. E. Contribuição do pai e da mãe no cuidado e proteção aos filhotes de Callithrix jacchus. In: RYLANDS, A. B.; BERNARDES, A. T. (eds.) A primatologia no Brasil - 3, Fundação Biodiversitas, 1991, p. 13-16.

ASSOCIATION OF THE OFFICIAL ANALITICAL CHEMISTS- A.O. A. C. Official and tetative methods of analysis. 16ed. Virginia, Arlington, AOAC International. 1995.

BAKER, I.K; DREUMEL, A.A.V. The alimentary system. In: JUBB, K.V.F. et al. (eds.) Pathology of Domestic Animals, vol 2. $4^{\text {th }}$ ed. New York, Academic Press, 1993. p. 118-22.

BARNARD, D.; KNAPKA, J.J. Callitrichid nutrition. In: CLAPP, N.K. A primate model for the study of colitis and colonic carcinoma - the cotton - top tamarin (Saguinus Oedipus). Boca Raton: CRC Press, 1993. p. 55-79.

BARNARD, D.; KNAPKA, J; RENQUIST, D. The apparent reversal of wasting syndrome by nutritional intervention in Saguinus mystax. Laboratory Animal Science, v. 38, p. 282-8, 1988.

BASKIN, G.B.; WOLF, R.H.; WORTH, C.L; SOIKE, K.; GIBSON, S.V.; BIERI, J.G. Anemia, steatitis, and muscle necrosis in marmosets (Saguinus labiatus). Laboratory Animal Science, v. 33, p. 74-80, 1983.

BEGLINGER, R.; ILLGEN, B.; PFISTER, R.; HEIDER, K. The parasite Trichospirura leptostoma associated with wasting disease in a colony of common marmosets, Callithrix jacchus. Folia Primatologica, v. 51, p. 45-51, 1988. 
BEGLINGER, R.; ILLGEN, B.; PFISTER, R.; HEIDER, K. The parasite Trichospirura leptostoma associated with wasting disease in a colony of common marmosets, Callithrix jacchus. Folia Primatologica, v. 51, p. 45-51, 1988.

BIRGEL, E. H. Patologia Clínica Veterinária. Apostila Cooper, 1983. 260 p.

BLAND, P.W. Mucosal T cell-epithelial cell interations. In: MAcDONALD, T. T. Chemical immunology, Basel, V. 71, p. 40-63, 1998.

BRACK, M. IgM-mesangial nephropathy in callitrichids. Veterinary Pathology, v.25, p. 270-6, 1988.

BRACK, M.; ROTHE, HF. Fütterungsbedingte "wating disease" bei weissrüscheläffchen (Calilthrix jacchus). Deutschen Primatenzentrum, Göttingen, p. 181-184, 1981.

BRACK, M.; ROTHE, H. Chronic tubulointerstitial nephritis and wasting disease in marmosets (Callithrix jacchus). Veterinary Pathology, v. 18, p. 45-54, 1981. Supplementum 6.

BRACK, M.; SCHOROEDER, C.; FOOKE, M.; SCHLUMBERGER, W. IgM/IgA nephropathy in callitrichids: antigen studies. Nephron, v.82, p. 221-231, 1999.

BRACK, M.; WEBER, M. Ultrastructural and histochemical mesangial alterations in callitrichid IgM nephropathy (Primates: Platyrrhina). Nephron, v. 69, p. 286-92, 1995.

BRADY, A.G.; MORTON, D.G. Digestive system. In: BENNETT, B.T.; ABEE, C.R; HENRICKSON, R. (eds.) Nonhuman primates in Biomedical Research - Diseases. San Diego, Academic Press, 1998. p . 377-414.

BRANDTZAEG, P.; FARSTAD, I.N.; HELGELAND, L. Phenotypes of T cell in the gut. In: MAcDONALD, T.T. Chemical Immunology, Basel, v. 71, p.1-26, 1998.

BRIAN, D. A.; SCHOCLEY, L.J. Coronaviruses in tamarin and marmoset colitis. In: CLAPP, N.K. A primate model for study of colitis and colonic carcinoma - the cottontop tamarin (Saguinus Oedipus). Boca raton: CRC Press, 1993. p. 145-159.

BROWN, B. Discussion 2. Digestive Disease and Science, v.30, p.82S-84S, 1985. Supplement.

BURROWS, C.F.; BATT, R.M.; SHERDING, R.G. Diseases of the small intestine. In: ETTINGER, S.J.; FELDMAN, E. C. Textbook of veterinary internal medicine - diseases of the dog and cat. 4ed. Philadelphia: W. B. Daunders Company, 1995. p. 1169-1232.

CARCIOFI, A. C. Avaliação da dieta à base de sementes e frutas para papagaios (Amazonas sp.). Determinação da seletividade dos alimentos, consumo, composição nutricional, digestibilidade e energia metabolizável. 1996. 104f. Dissertação (mestrado em 
Clínica Veterinária) - Faculdade de Medicina Veterinária e Zootecnia, Universidade de São Paulo, 1996.

CATON, J.M.; HILL, D.M.; HUME, I.D.; CROOK, G.A. The digestive strategy of the common marmoset, Callithirx jacchus. Comp. Biochem. Physiol., v. 114 ${ }^{\mathrm{A}}$, p. 1-8, 1996.

CHADWICK, D.P.; MAY, J.C.; LORENZ, D. Spntaneous zinc deficiency in marmosets, Saguinus mystax. Laboratory Animal Science, v. 29, p. 482-5, 1979.

CHALIAFOUX, L.V.; BRONSON, R.T.; ESCAJADILLO, A.; McKENNA, S. An analysis of the association of gastroenteric lesions with chronic wasting syndrome of marmosets.

Veterinary Pathology, v. 19, p. 141-62, 1982. Supplementum 7.

CHALIAFOUX, L.V.; BRONSON, R.T.; ESCAJADILLO, A.; McKENNA, S. An analysis of the association of gastroenteric lesions with chronic wasting syndrome of marmosets.

Veterinary Pathology, v. 19, p. 141-62, 1982. Supplementum 7.

CHALIFOUX, L.V.; KING, N.M.; JOHNSON, L.D. Acute and chronic colitis, cotton-top tamarins. In: JONES, T.C.; MOHR, U.; HUNT, R.D. (eds.) Nonhuman Primates II monographs on pathology of laboratory animals. Berlin, Springer-Verlag, 1993. p. 75-81.

CHALMERS, D.T.; MURGATROYD, L.B.; WADSWORTH, P.F. A survey of the pathology of marmosets (Callithrix jacchus) derived from a marmoset breeding unit. Laboratory

Animals, v. 17, p. 270-9, 1983.

CHANDRA, R.K. Immunodeficiency in undernutrition and overnutrition. Nutrition Reviews, v. 39, p. 225-31, 1981.

CLAPP, N. K. A primate model for the study of colitis and colonic carcinoma - the cotton-top tamarin (Saguinus oedipus). Boca-Raton: CRC Press, 1993, 330p.

CLAPP, N.K.; TARDIF, S.D. Marmoset husbandry and nutrition. Digestive Disease and Science, v. 30, p. 17S-23S, 1985. Supplement.

COIMBRA-FILHO, A.F. Aspectos inéditos do comportamento de sagüis do gênero Callithrix (Callitrichidae, Primates). Revista Brasileira de Biologia, v. 32, n. 4, p. 505-512, 1972.

COIMBRA-FILHO, A.F.; MAIA, A.A. A alimentação de sagüi em cativeiro. Brasil florestal, v. 29, p.15-26, 1977.

COIMBRA-FILHO, A.F.; MITTERMEIER, R.A. Exudate-eating tree-gouging in marmosets. Nature, v. 262, n. 5569, p. 630, 1976. 
COIMBRA-FILHO, A.F.; MITTERMEIER, R.A. Tree-gouging, exudate-eating and the "short-tusked"condition in Callithirx and Cebuella. In: KLEIMAN, D.G. (Ed.) Biology and Conservation of the Callitrichidae. washington, Smithsonian Institution, 1977. p .105-115.

COIMBRA-FILHO, A.F.; SILVA, R.R.; PISSINATTI, A. sobre a dieta de Callitrichidae em cativeiro. Revista Biotérios v.1, p: 83-93, 1981.

COLES, E.H. Veterinary Clinical Pathology, $4^{\mathrm{a}}$ ed., W.B. Saunders Company, Philadelphia, 1986. $152-170 \mathrm{p}$.

COUTINHO, P.E.G.; CÔRREA, H.K.M. Polygyny in a free-rangun group of buffy-tuffed-ear marmosets, Callithrix aurita. Folia Primatologica, v. 65, p. 25-29, 1995.

CRAIG, R.M.; ATKINSON JR, A.J. D-xylose testing: a review. Gastroenterology, n.95, p. 223-231, 1988.

CRAWFORD, J.M. The gastrointestinal tract. In: COTRAN, R.S.; KUMAR, V.; COLLINS, T. (eds.) Robbins Pathologic Basis of Disease. Philadelphia, W.B. Saunders, 1999. p .775843.

CRIEESY, S.D.; PRIBYL, L.S. Utilizing wild foraging ecology information to provide captive primates with an appropriate diet. Proceedings of the Nutrition Society, v.56, p. 1083-1094, 1997.

CROOK, G. A nutritional reversal of marmoset wasting syndrome. Australian Primatology, v. 4, p. 21, 1989.

DAVIS, W. C.; HAMILTON, M. J. Comparison of the unique characteristics of the immune system in different species of mammals. Veterinary Immunology and Immunopathology, v. 563, p. 7-13, 1998.

de FREITAS, I.N.; SIPAHI, AM.; DAMIÃO, A. O MC; de BRITO, T.; CAN;CADO, E.L.R.; LESER, P.G.; LAUDANNA, A A Celiac disease in brazilian adults. Journal of Clinical Gastroenterology, v. 34, p. 430-434, 2002.

DEINHARDT, F. Nutritional requirements of marmosets. In: HARRIS, R.S. Feeding and Nutrition of Nonhuman primates. New York, Academic press, 197-, p. 175-182.

DIAS, J.L.C.; MONTALI, R.J.; STRANDBERG, JD; JOHNSON, L.K.; WOLFF, M.J. Endocrine neoplasia in New World primates. Journal of Medical Primatalogy, v. 25, p. 3441, 1996.

DIGBY, L.J.; BARRETO, C.E. Social organization in a wild population of Callithrix jacchus. I. Group composition and dynamics. Folia Primatologica, v. 61, p. 123-34, 1993. 
DINIZ, L.S.M.; da-COSTA, E.O. Health problems of Callithrix jacchus in captivity. Brazilian Journal of Medical and Biological Research, v. 28, p. 61-4, 1995.

DOE, W.F. The intestinal immune system. Gut, v. 30, p. 1679-1685, 1989.

DROSSMAN, D.A Is the cotton-topped tamarin a model for behavioral research? Digestive Disease and Science, v. 30, p. 24S-27S, 1985. Supplement.

DUARTE, M.I.S.; MARIANO, O.N.; TAKAKURA, C.F.H.; EVERSON, D.; CORBET, C.E.P. A fast method for processing biologic material for electron microscopic diagnosis in infectious disease. Ultraestructural Pathology, v. 16, p. 475-482, 1992.

DUBOIS, R. Zoonoses transmissíveis por primatas no Brasil. A Hora Veterinária, v. 90, p. 21-4, 1996.

DUNCAN, J.R.; PRASSE, K.W. (eds.) Veterinary Laboratory Medicine - clinical pathology, $2^{\mathrm{a}}$ ed, Iowa, Iowa State university press, 1986. 285 p.

EBERTS, T.J.; SAMPLE, R.H.B.; GLICK, M.R.; ELLIS, G.H. A simplified, colorimetric micromethod for xylose in serum or urine, with Phloroglucinol. Clinical Chemistry, v. 25 , n.8, p. 1440-1443, 1979.

EICHLER, E.E.; DeJONG, P.J. Biomedical applications and studies of molecular evolution: a proposal for primate genomic library resource. Genome Research, V. 12, p. 673-678, 2002.

ELWOOD, C.M.; GARDEN, O.A. Gastrointestinal immunity in health and disease.

Veterinary Clinics of North America: small animal practice, v. 29, n.2, p. 471-500, 1999.

ELY, A.; FREER, A.; WINDLE, C.; RIDLEY, R.M. Assessment of cage use by laboratorybred common marmosets (Callithrix jacchus). Laboratory Animals, v. 32, p. 427-33, 1998.

EMMONS, L.H. Neotropical Rainforest Mammals, a field guide. Chicago, The University of Chicago Press, 1990. 281p.

EPIPHANIO, S. Patologia Comparada de Primatas da Família Callitrichidae Gray, 1821 Mantidos em Cativeiro. São Paulo, 1997. 108p. Dissertação (mestrado) - Faculdade de Medicina Veterinária e Zootecnia, Universidade de São Paulo.

ESCAJADILHO, A.; BRONSON, R.T.; SEHGAL, P.; HAYES, K.C. Nutritional evaluation in cotton-top tamarins (Saguinus oedipus). Laboratory Animal Science, v. 31, p. 161$165,1981$. 
ESTES, M.K. Evaluating viral agents in marmosets colitis. Digestive Disease and science, v. 30, p. 80S-81S, 1985. Supplement.

FARIA, D.S. O estudo de campo do mico-estrela Callithrix penicillata do Palnalto Central brasileiro. In: ADES, C. Etologia de animais e de homens. São Paulo: Edicon, 1986. p. 109121.

FARRELL, R.J.; KELLY, C.P. Celiac sprue. The New England Journal of Medicine v.346, p. 180-188, 2002.

FERRARI, S.F.; LOPES, M. A.; KRAUSE, E.A.K. Brief communication: gut morphology of Callithrix nigriceps and saguinus labiatus from western brazilian amazonia. American Journal of Physical Anthropology, v. 90, p. 487-493, 1993.

FERRARI, S.F.; MARTINS, E.S. Gummivory and gut morphology in two sympatric callitrichids (Callithrix emiliae and Saguinus fuscicollis weddelli) from western brazilian amazonia. American Journal of Physical Anthropology, v. 88, p. 97-103, 1992.

FLURER, C.; SCHEID, R.; ZUCKER, H. Evaluation of a pelleted diet in a colony of marmosets and tamarins. Laboratory Animal Science, v. 33, p. 264-7, 1983.

FLURER, C.I.; ZUCKER, H. Coprophagy in marmosets dur to insufficient protein (amino acid) intake. Laboratory Animals, v. 22, p. 330-1, 1988.

GANONG, W.F. Digestão e Absorção. In: Fisiologia Médica. 14 ed. Rio de Janeiro: McGran Hill, 2000. p. 339-373.

GARSIDE, P.; MOWAT, A. M. Mechanisms of oral tolerance. Critical reviews in immunology,v. 17, p. 119-137, 1997.

GEIST, C.R.; ZIMMERMANN, R.R.; STROBEL, D.A. Effect of protein-calorie malnutrition on food consumption, weight gain, serum proteins, and activity in the developing rhesus monkey (Macaca mulatta). Laboratory Animal Science, v. 22, n. 3, p. 369-377, 1972.

GERMAN, A.J.; HALL, E.J.; DAY, M.J. Analysis of leucocyte subsets in the canine intestine. Journal of comparative pathology, v. 120, p. 129-145, 1999.

GHEBREMESKEL, K.; WILLIAMS, G.; HARIGEL, L.; SPADETTA, M.; SUMMERS, P. Plasma vitamins $A$ and $E$ and hydrogen peroxide-induced in vitro erythrocyte haemolysos in common marmosets (Callithrix jacchus). Veterinary record, v. 126, n. 17, p. 429-431, 1990.

GIBSON S.V. Bacterial and mycotic disease. In: BENNETT, B.T.; ABEE, C.R; HENRICKSON, R. (eds.) Nonhuman primates in Biomedical Research - Diseases. San Diego, Academic Press, 1998. p. 59-110. 
GOGGINS, M., KELLEHER, D. Celiac disease and other nutrient related injuries to the gastrointestinal tract. The American Journal of Gastroenterology v. 89 (8), p. S2- S17, 1994.

GÓMEZ, J.; GONZÁLEZ, A. MARTÍNEZ-A, C.; REBOLLO, A. IL-2 induced cellular events. Critical reviews in immunology, v. 18, p. 185-220, 1998.

GORE, MA; BRANDES, F, KAUP, F-J; LENZNER, R.; MOTHES, T.; OSMAN, AA Callithrichid nutrion and food sensitivity. Journal of Medical Primatology v. 30, p 179-184, 2001.

GORE, MA; BRANDES, F, KAUP, F-J; LENZNER, R.; MOTHES, T.; OSMAN, AA Callithrichid nutrion and food sensitivity. Journal of Medical Primatology v. 30, p 179-184, 2001.

GOZALO, A.; MONTOYA, E. Mortality casuses of the moustached tamarin (Saguinus mystax) in captivity. Journal of Medical Primatology, v. 21, p. 35-8, 1991.

GREEMBERGER, N.J.; ISSELBACHER, K. J. Disorders of absorption. In: Harrison's principles of internal medicine, 1994. p. 1386-1403.

GREEN, P.H.R.; JABRI, B. Celiac disease. The Lancet, v. 363, p. 383-391, 2003.

GROVES, C. Primates taxonomy. Washington: Smithsonian Institute Press, 2001. 350p.

GUADALINI, S.; GOKHALE, R. Update on immunologic basis of celiac disease. Current opinion in gastroenterology, v. 18, p. 95-100, 2002.

GUYTON, A.C.; HALL, J.E. General principles of gastrointestinal function-motility, nervous control, and blood circulation. In:__ Text Book of Medical Physiology. 9 ed. PHILADELPHIA: W. B. SAUNDERS COMPANY, 1994. P. 793-844.

HALL, E. BATT, R.M. Development of wheat-sensitive enteropathy in Irish Seter: biochemical changes. American Journal of Veterinarian Research, v. 51, p. 983, 1994a.

HALL, E. BATT, R.M. Development of wheat-sensitive enteropathy in Irish Seter: morphologic changes. American Journal of Veterinarian Research, v. 51, p. 978, 1994b.

HALL, E.J.Clinical laboratory evaluation of small intestinal function. Veterinary Clinics of North America: small animal practice, v. 29, n.2, p. 441-469, 1999.

HARRIS, R.L.; STREETT, J.W.; MORROW, D., LORD, P.F. Villus atrophy and malabsorption in a rhesus monkey. Laboratory Animal Science, v. 34, p. 610-613, 1984. 
HAWKEY, C. M. Is the presence of Heinz bodies a useful diagnostic sign of "wasting marmoset syndrome". In: TUCKER, M.J.; WADSWORTH, P.F. Symposium on Marmoset Pathology, 1984. p. 30-40.

HAWKEY, C.M.; HART, M.G. Is the presence of Heinz bodies diagnostic for "wasting marmoset sybdrome"? Medical Laboratory Sciences, v.43, p. S28, 1986. Supplementum 1.

HAWKINS, K.I. Pediatric xylose absorption test: measurements in blood preferable to measurements in urine. Clinical Chemistry, v. 16, n.6, p. 749-752, 1970.

HAYES, K.C. Pathophysiology of vitamin E deficiency monkeys. The American Journal of Clinical Nutritionn, v.27, p. 1130-40, 1974.

HETHERINGTON, C.M. cicardian oscillations of body temperature in the marmoset, Callithrix jacchus. Laboratory Animals, v. 12, p. 107-108, 1978.

HILTON-TAYLOR, C (compilier) IUCN red list of threatened species. IUCN, 2000. Switzerland, 61p.

HOLMES, R.; LOBLEY, R. W. Intestinal brush border revisited. Gut, v. 30, p. 1667-1678, 1989.

HSU, S.M.; RAINE, L. The use of avidin-biotin-peroxidase complex (ABC) in imunoperoxidase techiniques: a comparison between $\mathrm{ABC}$ and unlabelled antibody (PAP) procedures. Journal Histochemistry and Citochemistry, v. 29, p. 577-80, 1981.

IALEGGIO, D.M.; BAKER, A.J. Results of a preliminary survey into wasting marmoset syndrome in callitrichid collections. In: Annual Conference of Nutrition Advisory Group, 1., 1995, Toronto. Proceedings...Toronto: Nitrition Advisory Group - NAG, 1995. Disponível em : <wwwnagonline.net/ proceedings $>$ Acesso em: 10 de maio de 2004.

INGRAM, J.C. Husbandry and observation methods of a breeding colony of marmosets (Callithrix jacchus) for behavioural research. Laboratory Animals, v. 9, p. 249-59, 1975.

IPS INTERNATIONAL GUIDELINES FOR THE ACQUISITION, CARE AND BREEDING OF NONHUMAN PRIMATES. Primate Report, v. 25, p. 3-27, 1989.

IPS INTERNATIONAL GUIDELINES FOR THE ACQUISITION, CARE AND BREEDING OF NONHUMAN PRIMATES. Primate Report, v. 35, p. 3-29, 1993.

JAMES, P.S.; KIYONO, H. Gastrointestinal lamina propria T cells. In: Mucosal Immunology. Philadelphia: Academic press, 1999. p. 381-396.

JAMES, S.P.; KWAN, W.C.; SNELLER, M.C. T cells in inductive and effector compartments of the intestinal mucosal immune system of nonhuman primate differ in 
lymphokine mRNA expression, lymphokine utilization, and regulatory function. Journal Immunology, v. 144, p. 1251, 1990.

JANEWAY JR, C.A. et al. Immunobiology- the immune system in health and disease. 4 ed. London, Current Biology Publications, 1999. 635p.

JENNINGS, J.S.R.; HOWDLE, P. D. Celiac disease. Current opinion in gastroenterology, v. 17, p. 118-126, 2001.

JERGENS, A.E. et al. Idiopatic inflammatory bowel disease in dogs and cats: 84 cases (19871990). Journal of American Veterinary Medical Association, v. 201, p. 1603-1608, 1992.

JOHNSON, D.R. Immune function in marmosets: present state of relevant knowledge. Digestive Disease and Science, v. 30, p. 61S-66S, 1985. Supplement.

JOHNSON-DELANEY, C.A. Primates. Veterinary Clinics of North America: Small Animal Practice, v. 24, p. 121-56, 1994.

JUAN-SALLÉS, C; VALLS, X.; MARCO, A.; VERGÉS, J.; BALDÉ, M.; DOMINGO, M. Anemia, myopathy, and/or steatitis in New World monkeys-vitamin E and/or selenium deficiency? In: AMERICAN ASSOCIATION OF ZOO VETERINARIANS AND AMERICAN ASSOCIATION OF WILDLIFE VETERINARIANS (joint conference), Omaha, Nebraska, 1998. Proceedings, p. 74-8.

JUAN-SALLÉS, C.; PRATS, N.; RESENDES, A.; DOMINGO, M.; HILTOND.; RUIZ, J.M.; GARNER, M.M.; VALLS, X.; MARCO, A.J. Anemia, myopathy, and pansteatitis in vitamin E- deficient captive marmosets (Callithrix spp.) Veterinary Pathology, v. 40, p. 540-547, 2003.

JUNIOR, P.E.P.; GAMA, A.H.; TEIXEIRA, M.G.; FERRINI, M.T.;RODRIGUES, J.J.G. Moléstia Inflamatória Intestinal. In: In: WAITZBERG, D.L. (ed.) Nutrição Enteral e parenteral na Prática Clínica. São Paulo, Atheneu, 2 ed, 1997. p. 426-431.

KAGNOFF, M.F. Celiac disease: a gastrointestinal disease with environmental, genetic, and immunologic components. Gastroenterology Clinics of North America, v. 21, p. 405-425, 1992.

KANE, A.B.; KUMAR, V. Environmental and nutritional pathology. In: COTRAN, R.S.; KUMAR, V.; COLlinS, T. (eds.) Robbins Pathologic Basis of Disease. Philadelphia, W.B. Saunders, 1999. p .403-457. 
KANE, A.B.; KUMAR, V. Environmental and nutritional pathology. In: COTRAN, R.S.; KUMAR, V.; COLlINS, T. (eds.) Robbins Pathologic Basis of Disease. Philadelphia, W.B. Saunders, 1999. p .403-457.

KING, N.W.Jr. Vitamin E-responsive hemolytic anemia and necrotizing myopathy, owl monkeys. . In: JONES, T.C.; MOHR, U.; HUNT, R.D. (eds.) Nonhuman Primates II monographs on pathology of laboratory animals. Berlin, Springer-Verlag, 1993. p. 226232.

KIRKWOOD, J.K.; EPSTEIN M.A.; TERLECKI, A.J. Factors influencing population growth of a colony of cotton-top tamarins. Laboratory Animals, v. 17, p. 35-41, 1983.

KITCHEN, A.M.; MARTIN, A.A. The effects of cage size and complexity on the behaviour of captive common marmosets, Callithrix jacchus jacchus. Laboratory Animals, v. 30, p. 317-26, 1995.

KNAPKA, J.J.; BARNARD, D.E.; BAYNE, K.A.L.; LEWIS, S.M.; MARRIOTT, B.M.; OFTEDAL, O. NUTRITION. In: BENNETT, B.T.; ABEE, C.R.; HENRICKSON, R. (eds.) Nonhuman Primates in Biomedical Research: biology and management. San Diego, Academic Press, 1995. p. 211-248.

LACHAUX, A.; LORAS-DUCLAUX, I; BOUVIER, R. Autoimune enteropathy in infants pathological study of the disease in two familial cases. Virchwos Arch, v. 433, p. 481-5, 1998.

LAYNE, D.G.; POWER, R.A. Husbandry, handling, and nutrition for marmosets.

Comaprative medicine, v. 53, n.4, p.351-359, 2003.

LEITE, M.C.P. Patologia comaprada de callithrix geoffroyi Humbolt, 1812 (Callitrichidae - Primates) mantidos em cativeiro do centro de primatologia do Rio de Janeiro. 2002. 206f. Dissertação (mestrado em Ciências) - Faculdade de Medicina Veterinária e Zootecnia, Universidade de São Paulo, 2002.

LEWIS, D.H.; STEIN, F.J.; McMURRAY, D.N. Fecal microflora of marmosets with wasting marmoset syndrome. Laboratory Animal Science, v. 37, p. 103-5, 1987.

LINDLEY, K.J.; MAcDONALD, S. Malabsorption in children. The practioner, v. 245, p. 162-183, 2001.

LOGAN, A.C.; KHAN, K.N. Clinical pathologic changes in two marmosets with wasting syndrome. Toxicologic Pathology, v. 24, n.6, p. 707-709, 1996.

LOWENSTINE, L.J. Neoplasms and proliferative disorders in nonhuman primates. In: BENIRSCHKE, K. Primates the road to self-sustaing populations. New York, SpringerVerlag, 1986. p. 781-814. 
LUDLAGE, E.; MANSFIELD, K. Clinical care and diseases of the common marmoset (Callithrix jacchus).Compartive medicine, v. 53, n. 4, 369-382, 2003.

LUSHBAUGH, C.; HUMANSON, G.; CLAPP, N. Histology of colitis: Saguinus oedipus oedipus and other marmosets. Digestive Disease and Science, v. 30, p. 45S-50S, 1985. Supplement.

MACHADO, A.A.S.; LEITE, O.C. Goma de cajueiro. Boletim do Instituto de Guímica Agrícola, n.50, p. 7-15, 1957.

MADARA, J.L.; TRIER, J.S. The functional morphology of the mucosa of the small intestine. In: JOHNSON, L.R. Physiology of the Gastroentestinal Tract. 3.ed. New York: Raven Press, 1994. p. 1577-1622.

MAIURI, L. et al. Interleukin 15 mediates epithelial changes in celiac disease.

Gastroenterology, v. 119, p. 996-1006, 2000.

MAIURI, L. et al. FAS engagement drives apoptosis of enterocytes of celiac patients. Gutv.48, p. 418-424, 2001.

MÄKI, M.; COLLIN, P. Coeliac disease. The Lancet, v. 349, p. 1755-1759, 1997.

MANOCHA, S.L. Experimental protein malnutrition in primates histochemical studies on the dorsal root ganglion cells of healthy and malnourished squirrel monkeys. Saimiri sciureus. Acta Histochemical Bd., v. 47, S.220-232, 1973.

MANSFIELD, K. Marmoset models commonly used in biomedical research. Comparative Medicine, v.53, n.4, p. 383-392, 2003.

MANSFIELD, K.; KING, N. Viral diseases. In: BENNETT, B.T.; ABEE, C.R; HENRICKSON, R. (eds.) Nonhuman primates in Biomedical Research - Diseases. San Diego, Academic Press, 1998. p . 1-57.

MARKS, S.L. Management of canine inflammatory bowel disease. Compedium Continuing Education for Practicing Veterinary, v. 20, p. 317-331, 1998.

MARTINS CAMPOS, J.V. Anatomia funcional. In: DANI, R.; CASTRO, L.P.

Gastroenterologia clínica, v. 1, 3ed. Rio de janeiro: Guanabara Koogan, 1993. p. 674-704.

MAZANEC, M.B. et al. A three-tiered view of the role of IgA in mucosa defence.

Immunology Today, v. 14, p. 430, 1993.

McNEELY, M. D.D. D-Xylose. In: PESCE, A.J.; KAPLAN, L.A. Methods in Clinical Chemistry. The C.V. Mosby Company, Washington, D.C. 1987. p. 862-867. 
McNEES, D.W.; LEWIS,R.W.; PONZIO, B.J.; STEIN, F.J.; SIS, R.F. Carbohydrate tolerance, serumalbumin and protein values of normal and "waster" marmosets (Callithrix jacchus). Primates, v. 24, p. 537-45, 1983.

MESTECKY, J.; RUSSELL, M.W. Passive and active protection against disorders of the gut. The veterinary Quarterly, v. 20 (supplement 3), p. S83-S86, 1998.

MIGAKI, G. Mycotic infections in nonhuman primates. In: BENIRSCHKE, K. Primates the Road to Self-Sustaining Populations. New York, Springer-Verlag, 1986. p .557-570.

MIRAGLIA, T.; LEDOUX, L.; BRANCO, A.L.C. Histological and histochemical data on the intestinal tract of the marmoset (Callithrix jacchus). Acta Anatomica, v. 68, p. 459-472, 1967.

MITTERMEIER, R.A.; KONSTANT, W.R.; MAST, R.B. Use of neotropical and magasy primate species in biomedical research. American journal of Primatology, v.34, p.73-80, 1994.

MOLTENI, A.; REDDY, J.R.; SPARBERG, M; MASCHGAN, E.R. Chronic idiopathic diarrhea with enterocolitis and malabsorption in a captive, lowland gorilla - a case report. In: MOPNTALI, RJ; MIGAKI, G. (eds.). The conparative pathology of zoo animals. Washington, DC, Smithsonian Institution Press, 1980. p. 105-12.

MONTALI, R.J.; BUSH, M. Disease of the Callithrichidae. In: FOWLER, M.E.; MILLER, R.E. Zoo \& Wild Animal Medicine: Current Therapy 4. $4^{\text {th }}$. ed. Philadelphia, W.B. Saunders, 1999. p.369-79.

MOODIE, S.; CICLITIRA, P. Recent developments in celiac disease. Current Opinion in Gastroenterology, v.18, p.182-186, 2002.

MOORE, D. M. Hematology of nonhuman primates. In: FELDMAN, B.F.; ZINKL, J.G.; JAIN, N.C. Schaml's veterinary hematology. 5ed. Philadelphia: Lippincott Williams \& Wilkins, 2000. p. 1133-1144.

MOORE, R. Nonviral infectious agents and marmoset (Saguinus oedipus) colitis. Digestive Disease and Science, v. 30, p. 69S-71S, 1985. Supplement.

MOREIRA, L.F.S. et al. Ritmo circadiano da atividade motora do sagüi comum (Callithrix jacchus). In: RYLANDS, A.B.; BERNARDES, A.T. (eds.) A primatologia no Brasil - 3, Fundação Biodiversitas, 1991, p. 24-33.

MORIN, M.L. A different approach in examining a wasting syndrome. Laboratory Animal, v.12, n.3, p. 36-41, 1983.

MORIN, M.L. Colony management problems encountered in using marmosets and tamarins in biomedical research. Digestive Disease and Science, v. 30, p. 14S-16S, 1985. Supplement. 
MOWAT, A.M. Coeliac disease: a future for peptide therapy? The Lancet, v. 356, p. 270 $271,2000$.

MOWAT, A.M. Coeliac disease - a meeting point for genetics, immunology, and protein chemistry. The Lancet, v. 361, p. 1290-1292, 2003.

MULDER, C.J.J.; WAHAB, P.J..; MOSHAVER, B.; MEIJER, J.W.R. Refractory coeliac disease: a window between coeliac disease and enteropathy associated $\mathrm{T}$ cell lymphoma.

Scand J. Gastroenterol v.35, suppl 232:32-7, 2000.

MURGATROYD, L.B.; CHALMERS, D.T. A histological and histochemical study of normal and diseased muscle in marmosets Callithrix jacchus. Journal of Comparative Pathology, v. 90, p. 373-378, 1980.

NATIONAL REASERCH COUNCIL - NRC Nutritional requirements of nonhuman primates. 2 ed. Washington, Nacional Academies Press, 2003. 286 p.

NEUBERT, R.; FOERSTER, M. NOGUEIRA, A.C. HELGE, H. Cross-reactivity of antihuman monoclonal antibodies with cell surface receptors in the common marmoset. Life Sciences, v. 58, p. 317-324, 1996.

NIBLACK, G.D.; KATELEY, J.R.; GENGOZIAN, N. T - and b- lymphocyte chimerism in the marmoset.Immunology, v.32, p. 257-263, 1977.

NOWAK, R.M. Walker's Mammals of the World. $5^{\text {th }}$ ed. Baltimore: The Johns Hopkins University Press, 1991. p .400-514: Primates.

O’NEIL, P.A.; LEVY, B.M. Lymphocyte subsets in the young and aging marmoset (Callithrix jacchus). Journal Medical Primatology, v. 15, p. 409-417, 1986.

OFTEDAL, O.T.; ALLEN, M.E. The feeding and nutrition of ominivores with emphasis on primates. In: KLEIMAN, D.G.; ALLEN, M.E.; THOMPSON, K.V.; LUMPKIN, S. Wild mammals in captivity - principles and techniques. Chicago: Chigaco Press, 1996. p. 148156.

OLKOWSKI, Z.; MANOCHA, S.L. Experimental protein malnutrition in squirrel monkeys: reaction of the nissl substance in the motor neurons of the spinal cord. Histochemie, v. 30, p. 281-288, 1972.

PASCUAL, D.W.; KYIONO, H.; McCHEE, J.R. Mucosal immunity molecular and cellular aspects of immune protection to enteric infections. In: PARADISE, L.J.; BENDINELLI, M.; FRIEDMAN, H. Enteric infections and immunity. 1ed. New York: Plenum Press, 1996. p. $15-35$.

PEÑA, A.S.; CRUSIUS, J.B.A. Food allergy, coeliac disease and chronic inflammatory bowel disease in man. The Veterinary Quarterly, v. 20, p. S49-S51, 1998. Supplementum 3. 
PERDUE, M.H. Mucosal immunity and inflammation III. The mucosal antigen barrier: cross talk with mucosal cytokines. American Journal Physiology, v.227, p. G1-G5, 1999.

PEREIRA, L.H.; MELO, A.L. Observações sobre a criação de Callithrix penicillata (Primates, Callitrichidae) em cativeiro. In: CONGRESSO BRASILEIRO DE PRIMATOLOGIA, 1, Belo Horizonte, 1983. Anais. Belo Horinzonte: Sociedade Brasileira de Primatologia, 1983. p .129-32.

PETERS, V.M.; GUERRA, M.O. Reproduction and maintenance of two species of marmoset in captivity. Revista Brasileira de Biologia, v. 58, p. 169-73, 1998.

PETRAS, R.E. Nonneoplastic intestinal diseases. IN: STERNBERG, S.S., ed. Diagnostic Surgical Pathology, vol 2, $2^{\text {nd }}$ ed Raven Press, New York, 1994. p. 1311-1370.

PICUS, J.; ALDRICH, W.R.; LETVIN, N.L. A naturally occurring bone-marrow-chimeric primate. Transplantation, v. 35, p. 159-161, 1993.

PINHEIRO, E.S.; SIMON, F.; CASSARO, K.; SOARES, M.E.G. Outbreak of diarroea due Campylobacter jejuni in lion-tamarins (Leontopithecus spp.) in captivity. Verth. Ber. Erkrg.Zootiere, n. 35, p. 159-161, 1993.

PISSINATTI, A. Manejo, reprodução e utilização biomédica de espécies do gênero Callithrix (Erxleben, 1777). Callitrichidae - Primates. Revista Brasileira de Medicina Veterinária, v. 15, p. 57-61, 1993.

POND, W.G.; CHURCH, D.C.; POND, K.R. Basic animal nutrition and feeding. 4ed., New York, John Wiley, 1995.

POOLE, T.B.; EVANS, R. Reproduction, infant survival and productivity of a colony of common marmosets (Callithrix jacchus jacchus). Laboratory Animals, v. 16, p. 88-97, 1982.

POTKAY, S. Diseases of the Callitrichidae: a review.. Journal. Medical. Primatology, v.21, p. 189-236, 1992.

POWER, M.L.; OFTEDAL, O.T. Differences among captive callitrichids in the digestive responses to dietary gum. American Journal of Primatology, v. 40, p. 131-144, 1996.

QUARESMA, J.A.S. Arboviroses da Amazônia: estudo do mecanismo de morte celualr e da resposta fenotípica do hospedeiro da febre amarela. 2003. 162f. Tese (doutorado em Ciências) - Faculdade de Medicina veterinária, Universidade de São Paulo, São Paulo, 2003.

QUINT, D.J. et al. Immunoregulation in the common marmoset, Callithrix jacchus: functional properties of $\mathrm{T}$ and $\mathrm{B}$ lymphocytes and their response to human interleukins 2 and 4. Immunology, v. 69, p. 616-621, 1990. 
RANA, S.V.; GUPTA, D.; KTYAL, R.; SINGH, K. Mild-to-moderate malnutrition alters glutathione gamma-glutamyl-transpeptidades and glycine uptake in small intestine bruschborder vesicles of rhesus monkeys. Annais nutition \& metabolism, v. 45, p. 143-147, 2001.

REIF, S.; LERNER, A. Tissue transglutaminase-the key player in celiac disease: a review. Autoimmunity Reviews, v. 3, n.1, p. 40-45, 2004.

RICHTER, C.B. Biology and disease of Callitrichidae. In: FOX, J.G.; COHEN, B.J.; LOEW, F.M. (eds.) Laboratory Animal Medicine. San Diego, Academic Press, 1984. p. 353-383.

RICHTER, C.B.; LEHNER, N.D.M.; HENRICKSON, R.V. Primates. In: FOX, J.G.; COHEN, B.J.; LOEW, F.M. (eds.) Laboratory Animal Medicine. San Diego, Academic Press, 1984. p. 298-301.

RIDDEL, R.H. Inflammatory bowel disease: differential diagnosis and cancer of the small and large bowel. Digestive Diseases ans Sciences, V.30, P. 11S-13S, 1985. Supplement

RILEY, S.A.; TURNBERG, L.A. Maldigestion and malabsorption.In: SLEISENGER, M.H.; FORDTRAN, J.S. (eds.) Gastrointestinal Disease - pathophysiology, diagnosis, management. Philadelphia, W.B. Saunders Company, 1993. p. 1009-1026.

RODA, S.A., PONTES, A.R.M. Polygyny and infanticide in common marmosets in a fragment of the Atlantic Forest of Brazil. Folia Primatologica, v. 69, p. 372-6, 1998.

ROLSTON, D.D.K.; MATHAN, V.I. Xylose transport in the human jejunum.Digestive Disease and Science, v.34, p. 1553-1558, 1989.

ROTHE, H.; KOENIG, A. Variability of social Organization in Captive Common Marmosets (Callithrix jacchus). Folia Primatologica, v. 57, p. 28-33, 1991.

ROWE, N. The Pictorial Guide to the Living Primates. East Hampton, Pogonias Press, 1996. 263p.

RUSSELL, R.G; BRIAN, D.A; LENHARD, A; POTGIETER, L.N.D.; GILLESPIE, D.; CLAPP, N.K. Coronavirus-like particles and Campylobacter in marmosets with diarrhea and colitis. Digestive Disease and Science, v. 30, p. 72S-77S, 1985. Supplement.

RYLANDS, A.B.; SCHINEIDER, H.; LANGGUTH, A.; MITTERMEIER, R.A; GOVES, C.P.; RODRIGUEZ-LUNA, E. An assessment of the diversity of the New World primates. Neotropical primates, v.8, n.2, p.61-3, 2000.

RYLANDS, A.B. evolução do sistema de acasalamento em Calltrichidae. In: ADES, C. Ecologia de animais e de homens. São Paulo: edicon, 1986. p. 87-108. 
RYLANDS, A.B.; MITTERMEIER, R.A.; RODRÍGUEZ-LUNA, E. Conservation of neotropical primates: threatened species and na analysis of primate diversity by country and region. Folia Primatologica, v. 68, p. 134-60, 1997.

SÁ, L.R.M.; MIRANDOLA, R.M.S.; DUARTE, M.I.S. Wasting marmoset syndrome is a malabsorption process with features similar to celiac disease. In: AMERICAN

ASSOCIATION OF ZOO VETERINARIANS, 2002 conference. 2002, Milwaukee.

Proceedings...Milwaukee: American Association of zôo Veterinarian, 2002. p. 79-81.

\section{SÁ, L.R.M. Determinação e Caracterização de Enfermidades que Acometem}

Calitriquídeos e Cebídeos (estudo multidisciplinar). São Paulo, 1999. 174p. Dissertação (mestrado), Faculdade de Medicina Veterinária e Zootecnia, Universidade de São Paulo.

SAINSBURY, A.W.; KIRKWOOD, J.K.; APPLEBY, E.C. Chronic colitis in common marmosets (Callithrix jacchus) and cotton-top tamarins (Saguinus oedious). Veterinary

Records, v. 121, p. 329-30, 1987.

SANDERSON, I.R. The physicochemical environment of the neonatal intestine. American Journal of Clinical Nutrition, v.69, p. 1028-S-1034S, 1999. Suplementum.

SANDHYAMANI, S.; VIJAYAKUMARI, A.; BALARAMAN NAIR, M. Bonnet monkey model for pancreatic changes in induced malnutrition. Pancreas, v. 18, n.1, p.84-95, 1999.

SARSFIELD, P.; RINNE, A.; JONES, D.B.; JOHNSON, P.; WRIGHT, D.H. Accessory cells in physiological lymphoid tissue from the intestine: an immunohistochemical study.

Histopathology, v. 28, p. 205-211, 1996.

SCANLON, C.E.; CRUZ, M.A.O.M.; RYLANDS, A.B. Exploração de exsudatos vegetais pelo sagüi-comum, Callthrix jacchus. In: RYLANDS, A.B.; BERNARDES, A.T. (eds.) A primatologia no Brasil - 3, Fundação Biodiversitas, 1991, p. 197-205.

SCHERDING, R.G. Disease of the klarge intestine. In: TAMS, T.R. Handbook of small animal gastroenterology. Philadelphia, Saunders, 2003. p. 252-285.

SCHOOLEY, R.T.; BYINGTON, R.; FALK, JR, L.A. Phenotypic analysis of New World primate mononuclear cell surface antigens. Journal Medical Primatology, v. 12, p. 30-40, 1983.

SCHROEDER, C.; OSMAN, A.A.; ROGGENBUCK, D.; MOTHES, T. IgA-gliadin antibodies, IgA-containing immune complexes, and igA glomerular deposits in wasting marmoset syndrome. Nephrol Dial Transplant, v. 14, p. 1875-1880, 1999.

SCHUPPAN, D. Current concepts of celiac disease pathogenesis. Gastroenterology, v. 119, p. 234-242, 2000. 
SCULLION, F.T.; BROWN, P.J.; POTTS, E.A survey of the pathology in a breeding group of cotton top tamarins (Saguinus oedipus). Ver ber Erkr Zootiere, v. 29, p. 239-45, 1987.

SDEPADIAN, V.L.; MORAIS, M.B.; FAGUNDES-NETO, U. Doença celíaca: a evolução dos conhecimentos desde sua centenária descrição original até os dias atuais.Arq

Gastroenterol, v.36, n.4, p. 244-257, 1999.

SHAN, L. et al. Structural basis for gluten intolerance in celiac sprue.Science, v. 297, p. 2275-2279, 2002.

SHIMWELL, M.; WARRINGTON, B.F.; FOWLER, J.S.L. Dietary habits relating to "wasting marmoset syndrome" (WMS). Laboratory Animals, v. 13, p. 139-142, 1979.

SIBBALD, I.R. Measurement of bioavailable energy in poultry feeding stuffs: a review.Canadian Journal of Animal Science, v. 62, n.4, p. 983-1048, 1982.

SMITH, J.A.; BOYD, K.M.; The boyd group of papers on: the use of nohuman primates in research and testing.Animal technology and walfare, v. 2, n.2, p. 89-110, 2003.

SOLLID, L.M.; MOLBERG, O.; McADAMS, S.; LUNDIN, K.E. Autoantibodies in celiac disease: tissue transglutaminase - guilt by association. Gut v. 41, p. 851-852, 1997.

STEIN, F.J.; SIS, R.R.; LEVY, B.M. Indoor-outdoor housing systems for a self-sustaining marmoset breeding colony.laboratory Animal science, v. 29, n. 6, p. 805-808, 1979.

STERNBERG, S.S. (ed.) Histology for Pathologists, $2^{\mathrm{a}}$ ed., Philadelphia, Lippincott-Raven, 1997. 1200p.

STEVENSON, M.F.; RYLANDS, A.B. The marmosets, genus Callithrix. In: MITTERMEIER, R.A.; COIMBRA-FILHO, A.F.; FONSECA, G.A.B. (eds.) Ecology and Behavior of Neotropical Primates. Washington, dc, World Wildlife Fund, 1988. p. 131-222.

STROBER, S.; MOWAT, A.M. immune response to dietary antigens: oral tolerance. Immunology today, v. 19, p. 173, 1998.

STROBER, W.; FUSS, I.J. Gluten-sensitive enteropathy and other immunologically mediated enteropathies. In: Mucosal immunology. Philadelphia: Academic Press, 1999, p. 1101-1128.

SZABO, S. Understanding biologic stress for study design and interpretation results. Digestive Disease and Science, v. 30, p. 28S-31S, 1985. Supplement.

TAMS, T.R. Chronic canine lymphocytic plasmocytic enteritis. Compedium Continuing Education Practicing Veterinary, v. 9, p. 1184-91, 1987. 
TAMS, T.R. Handbook of small animal gastroenterology. Phialdelphia, Saundres, 2003. $486 \mathrm{p}$.

TARDIF, S.D. et al. Reproduction in captive common marmosets (Callithrix jacchus). Comparative medicine, v. 553, n.4, p. 364-368, 2003.

TARDIF, S.D.; CLAPP, N.K.; HENKE, M.A.; CARSON, R.L.; KNAPKA, J.J. Maintenance of cotton-top tamarins fed na experimental pelleted diet versus a higly diverse sweetened diet. Laboratory Animal Science, v. 38, p. 588-591, 1988.

TARDIF, S.D.; RICHTER, C.B.; CARSON, R.L. Reproductive performance of three species of Callitrichidae. Laboratory Animal Science, v. 34, p. 272-5, 1984.

THOMSON, J.S. The intestinal response to critical illness. The American Journal of Gastroenterology, v.90, n.2, p. 190-200, 1995.

TOFT, J.D.II; EBERHARD, M.L Parasitic disease. In: BENNETT, B.T.; ABEE, C.R; HENRICKSON, R. (eds.) Nonhuman primates in Biomedical Research - Diseases. San Diego, Academic Press, 1998. p . 111-205.

TRIER, J.S. Celiac sprue. In: SLEISENGER, M.H.; FORDTRAN, J.S. (eds.) Gastrointestinal Disease - pathophysiology, diagnosis, management. Philadelphia, W.B. Saunders Company, 1993. p. 1078-1095.

TUCKER, M.J. A survey of the pathology of marmosets (Callithrix jacchus) under experiment. Laboratory Animals v. 18, p. 351-358, 1984.

UIL, J.J. et al. Clinical implications of the sugar absorption test: intestinal permeability test to assess mucosal barrier function. Scand Journal Gastroenterology, v. 32 suppl 223, p. 70-78, 1997.

ULLREY, D.E.; BERNARD, J. B. Vitamin D: metabolism, souerces, unique problems in zoo animals, meeting needs. In: FOWLER, M.E.; MILLER, R.E. Zoo \& wild animal medicine: current therapy 4. Philadelphia, W.B. Saunders, 1999. p. 63-78.

WAGNER, J.D.; JEROME, C.P.; ADAMS, M.R. Gluten-sensitive enteropathy in a cynomolgus monkey.Laboratory Animal science, v. 38, n.5, p.592-594, 1988.

WAITZERG, D.L.; FERRINI, M.T. Avaliação Nutricional. In: WAITZBERG, D.L. (ed.) Nutrição Enteral e parenteral na Prática Clínica. São Paulo, Atheneu, $2^{\text {a }}$ ed, 1997. p. 127 152.

WATKINS, D.; ETEPHEN-HODI, F.; LETVIN, N.L. A primate species with limited major histocompatibility complex class I polymorphism. Proceedings National Academic Science, v. 85, p. $7714-7718,1988$. 
WEBER, H.; BERGE, E.; FINCH, J.; HEIDT, P.; KAUP, F-.J.; PERRETA, G.; VERSCHUERE, B.; WOLFENSOHN, S. health monitoring of non-human primate colonies. Laboratory Animals, v. 33, p. S3-S18, 1999. Supplementum 1.

WIRTH, H.; BUSELMAIER, W. Long-term experiments with a newly-developed standardized diet for the New World primates Callithrix jacchus jacchus and Callithrix jacchus penicillata (marmosets). Laboratory Animals, v. 16, p. 175-81, 1982.

WORLD HEALTH ORAGANIZATION 2000/ 2004. Conceitos. Disponível em: www.who.int. Acesso em: 17 de maio 2004.

WORLD HEALTH ORGANIZATION, Food and Nutrition Terminology: terminology circular $n^{\circ} 27$, World Health Organization, 1973.

WYKRZYKOWSKA, J.J.; PAULEY, D.R.; LACKNER, A.A.; SIMON, M.A. Evaluation of anti-human antibodies for immunohistochemistry on archival nonhuman primate tissues.

Journal Medical Primatology, v. 25, p. 71-77, 1996.

XAVIER, J.G. Repercussões estruturais da desnutrição protéica e renutrição em tecidos lino-hematopoéticos de camundongos. 1999. 254 f. tese (doutorado em $\mathrm{Ci} \sim$ encias) Faculdade de Medicina Vterinária e Zootecnia, Universidade de São paulo, 1999.

YAMAMOTO, M.E. Comportamento social do gênero Callithrix em cativeiro. In: RAYLANDS, A.B.; BERNARDES, A.T. (eds.)A primatologia no Brasil - 3, Fundação Biodiversitas, 1991, p. 63-81.

YARBROUGH, L.W.; TOLLETT, J.L.; MONTREY, R.D.; BEATTIE, R.J. serum biochemical, hematological and body measurement data for common marmosets (Callithrix jacchus jacchus). Laboratory Animal science, v. 34, p. 276-280, 1984.

YARDLEY, J.H. Malabsorptive disorders. In: MING, S-C; GOLDMAN, H. Pathology of the gastrointestinal tract. Philadelphia: W.B. Saundres Company, 1992. p. 752-767. 


\section{APÊNDICE A}

Tabela 10 - Avaliação histopatológica semi quantitativa do jejuno dos sagüis com SEP (grupo I) e sagüis controles (grupo III), segundo relação vilo/ cripta, comprimento de vilo, grau de hiperplasia da cripta, intensidade do processo inflamatório, infiltrados mononuclear, neutrofílico, eosinofílico, número de linfócitos intraepiteliais em cada 100 enterócitos

\begin{tabular}{cccccccccc}
\hline CASO & V/C & VILO & CRIPTA & PI & MON. & NEUT. & EOS. & LIE & grupo \\
\hline 1 & 2 & 2 & 3 & 2 & 2 & 0 & 0 & 1 & 1 \\
2 & 2 & 2 & 3 & 3 & 3 & 0 & 0 & 2 & 1 \\
3 & 3 & 3 & 3 & 2 & 2 & 0 & 0 & 2 & 1 \\
4 & 3 & 3 & 3 & 2 & 2 & 0 & 0 & 2 & 1 \\
5 & 2 & 2 & 3 & 2 & 2 & 0 & 0 & 1 & 1 \\
6 & 3 & 3 & 2 & 3 & 3 & 1 & 0 & 2 & 1 \\
7 & 2 & 2 & 2 & 2 & 2 & 1 & 0 & 2 & 1 \\
8 & 2 & 2 & 3 & 2 & 2 & 1 & 0 & 0 & 1 \\
9 & 2 & 2 & 3 & 2 & 2 & 0 & 0 & 2 & 1 \\
10 & 2 & 2 & 3 & 2 & 2 & 2 & 0 & 1 & 1 \\
11 & 2 & 2 & 3 & 3 & 3 & 2 & 0 & 1 & 1 \\
12 & 2 & 2 & 3 & 2 & 2 & 2 & 0 & 2 & 1 \\
13 & 2 & 2 & 3 & 2 & 2 & 0 & 0 & 1 & 1 \\
14 & 2 & 2 & 3 & 2 & 2 & 1 & 0 & 2 & 1 \\
15 & 3 & 3 & 3 & 2 & 2 & 0 & 0 & 1 & 1 \\
16 & 2 & 2 & 3 & 3 & 3 & 0 & 0 & 2 & 1 \\
17 & 2 & 2 & 3 & 3 & 3 & 1 & 0 & 2 & 1 \\
18 & 2 & 2 & 3 & 2 & 2 & 0 & 0 & 1 & 1 \\
19 & 2 & 2 & 2 & 2 & 2 & 0 & 0 & 2 & 1 \\
20 & 2 & 2 & 3 & 2 & 2 & 2 & 0 & 2 & 1 \\
\hline 21 & 0 & 0 & 0 & 0 & 1 & 0 & 0 & 0 & 3 \\
22 & 0 & 0 & 0 & 0 & 1 & 1 & 0 & 0 & 3 \\
23 & 0 & 0 & 0 & 1 & 1 & 1 & 0 & 1 & 3 \\
24 & 0 & 0 & 0 & 1 & 1 & 0 & 0 & 1 & 3 \\
25 & 0 & 0 & 0 & 0 & 1 & 0 & 0 & 0 & 3 \\
26 & 0 & 0 & 0 & 0 & 1 & 0 & 0 & 0 & 3 \\
27 & 0 & 0 & 0 & 0 & 1 & 0 & 0 & 0 & 3 \\
28 & 0 & 0 & 0 & 0 & 1 & 0 & 0 & 0 & 3 \\
\hline
\end{tabular}

$\mathrm{V} / \mathrm{C}=$ relação vilo/ cripta; $\mathrm{PI}=$ processo inflamatório; $\mathrm{MON} .=$ células mononucleares; Neut. = neutrófilos; EOS. = eosinófilos, LIE = número de linfócitos intraepiteliais/ 100 enterócitos. 


\section{APÊNDICE B}

Tabela 12 - Resultados da contagem de células imunomarcadas por área $\left(\mathrm{mm}^{2}\right)$, quanto aos fenótipos proteína $\mathrm{S} 100+$, linfócitos $\mathrm{B} \mathrm{CD} 20+$, linfócitos $\mathrm{T}$ CD45RO+, T CD8+, T CD4+ e imunoexpressão de interleucina 2, interleucina 4 , fator de necrose tumoral- $\alpha$ e interferon $-\gamma$, segundo os casos de sagüi com SEP (grupo I) e sagüis controles (grupo III)

\begin{tabular}{|c|c|c|c|c|c|c|c|c|c|c|}
\hline \multicolumn{11}{|c|}{ SAGÜIS COM SEP (GRUPO I) } \\
\hline CASOS & S100 & CD 20 & CD 68 & CD45RO & CD 8 & CD 4 & IL2 & IL4 & TNF- $\alpha$ & INF-Y \\
\hline 1 & 131,20 & 40,00 & 3,20 & 19,20 & 11,20 & 16,00 & 72,00 & 3,20 & 1,60 & 3,20 \\
\hline 2 & 80,00 & 41,60 & 1,60 & 11,20 & 3,20 & 4,80 & 22,40 & 0,00 & 0,00 & 0,00 \\
\hline 3 & 142,40 & 105,60 & 1,60 & 56,00 & 6,40 & 11,20 & 22,40 & 1,60 & 0,00 & 0,00 \\
\hline 4 & 89,60 & 102,40 & 4,80 & 30,40 & 8,00 & 27,20 & 28,80 & 0,00 & 1,60 & 0,00 \\
\hline 5 & 49,60 & 57,60 & 6,40 & 25,60 & 1,60 & 16,00 & 3,20 & 1,60 & 1,60 & 0,00 \\
\hline 6 & 424,00 & 64,00 & 1,60 & 68,80 & 4,80 & 1,60 & 3,20 & 0,00 & 0,00 & 0,00 \\
\hline 7 & 54,40 & 126,40 & 11,20 & 179,20 & 32,00 & 129,60 & $\ldots$ & $\ldots$ & $\ldots$ & $\ldots$ \\
\hline 8 & 30,40 & 307,20 & 3,20 & 107,20 & 28,80 & 204,80 & $\ldots$ & $\ldots$ & $\ldots$ & $\ldots$ \\
\hline 9 & 24,00 & 288,00 & 6,40 & 84,80 & 48,00 & 204,80 & $\ldots$ & $\ldots$ & $\ldots$ & $\ldots$ \\
\hline 10 & 16,00 & 148,80 & 17,60 & 60,80 & 11,20 & 332,80 & $\ldots$ & $\ldots$ & $\ldots$ & $\ldots$ \\
\hline 11 & 6,40 & 16,00 & 44,80 & 113,60 & 48,00 & 112,00 & $\ldots$ & $\ldots$ & $\ldots$ & $\ldots$ \\
\hline 12 & 9,60 & 264,00 & 59,20 & 27,20 & 65,60 & 160,00 & $\ldots$ & $\ldots$ & $\ldots$ & $\ldots$ \\
\hline 13 & 64,00 & 78,40 & 17,60 & 107,54 & 16,00 & 123,20 & $\ldots$ & $\ldots$ & $\ldots$ & $\ldots$ \\
\hline media & 86,28 & 126,15 & 13,78 & 68,58 & 21,91 & 103,38 & 25,33 & 1,07 & 0,80 & 0,53 \\
\hline Mediana & 54,40 & 102,40 & 6,40 & 60,80 & 11,20 & 112,00 & 22,40 & 0,80 & 0,80 & 0,00 \\
\hline Desv. Pad. & 110,43 & 98,75 & 18,07 & 48,74 & 20,76 & 102,96 & 25,25 & 1,31 & 0,88 & 1,31 \\
\hline \multicolumn{11}{|c|}{ SAGÜIS CONTROLES (GRUPO III) } \\
\hline CASOS & $\mathrm{S} 100$ & CD20 & CD68 & CD45RO & CD8 & CD4 & IL2 & IL4 & TNF & INF \\
\hline 1 & 115,20 & 68,80 & 1,60 & 59,20 & 8,00 & 11,20 & 1,60 & 1,60 & 0,00 & 0,00 \\
\hline 2 & 97,60 & 8,00 & 1,60 & 20,80 & 0,00 & 1,60 & 0,00 & 0,00 & 0,00 & 0,00 \\
\hline 3 & 48,00 & 4,80 & 1,60 & 4,80 & 1,60 & 1,60 & 1,60 & 0,00 & 0,00 & 0,00 \\
\hline 4 & 110,40 & 80,00 & 1,60 & 9,60 & 4,80 & 4,80 & 0,00 & 0,00 & 0,00 & 0,00 \\
\hline 5 & 124,80 & 89,60 & 3,20 & 24,00 & 25,60 & 4,80 & 1,60 & 0,00 & 0,00 & 0,00 \\
\hline 6 & 62,40 & 19,20 & 1,60 & 6,40 & 0,00 & 19,20 & 1,60 & 1,60 & 0,00 & 0,00 \\
\hline media & 93,07 & 45,07 & 1,87 & 20,80 & 6,67 & 7,20 & 1,07 & 0,53 & 0,00 & 0,00 \\
\hline Mediana & 104,00 & 44,00 & 1,60 & 15,20 & 3,20 & 4,80 & 1,60 & 0,00 & 0,00 & 0,00 \\
\hline Desv. Pad. & 30,95 & 38,55 & 0,65 & 20,36 & 9,78 & 6,84 & 0,83 & 0,83 & 0,00 & 0,00 \\
\hline
\end{tabular}

$\mathrm{S} 100=$ célula dendrítica $\mathrm{S} 100+; \mathrm{CD} 20=$ linfócito $\mathrm{B}-\mathrm{CD} 20+; \mathrm{CD} 68=$ macrófago $\mathrm{CD} 68+$; $\mathrm{CD} 45 \mathrm{RO}=$ linfócito $\mathrm{T}$ CD45RO+, CD8=linfócito T CD8+; CD4=linfócito CD4+, IL2= interleucina 2; IL4=interleucina 4, TNF=fator de necrose tumoral $-\alpha$; IFN=interferon $-\gamma$ 


\section{EXAME COPROLÓGICO FUNCIONAL}

\section{Considerações gerais}

O exame macro e microscópico das fezes têm valor em casos de pancreatite crônica, atrofia acinar pancreática, fibrose pancreática e como diferencial das síndromes de mádigestão e má-absorção.

\subsection{Preparo das soluções}

\subsubsection{Corante Sudam III 3\%}

- Sudam III $3 g$

- Álcool 70\% 50ml

- Acetona PA 50ml

Misturar inicialmente o álcool e a acetona. Colocar o corante pesado em um frasco âmbar e adicionar a mistura álcool-acetona. Homogeneizar. Filtrar antes do uso.

\subsubsection{Solução de Lugol (iodo 2\%)}

- Iodo ressublinado $5 \mathrm{~g}$

- Iodeto de potássio (KI) $10 \mathrm{~g}$

- Água purificada ou destilada $100 \mathrm{ml}$

Triturar e misturar o iodo ressublinado e o iodeto de potássio com pistilo em um graal. Acrescentar a água. Se necessário diluir $10 \%$ antes do uso.

\subsubsection{Solução de bicarbonato de sódio $5 \%$}

- Bicarbonato de sódio $25 \mathrm{~g}$

- Água purificada ou destilada $100 \mathrm{ml}$

Misturar em balão volumétrico e agitar até dissolver completamente.

1.1.4. Preparo da gelatina $7,5 \%$

- gelatina em pó 7,5 g

- água purificada ou destilada $100 \mathrm{ml}$

Misturar até homogeneizar a solução. Pipetar 1,0ml da solução em tubos de ensaio pequenos com rolhas. Conservar em geladeira até o uso. Aquecer em banho-maria $37^{\circ} \mathrm{C}$ antes do uso. 
1.1.5. Solução $1: 10$ de fezes

- Fezes $0,25 \mathrm{~g}$

- Água purificada ou destilada $2,25 \mathrm{ml}$

Misturar bem.

1.1.6. Solução 1:50 de fezes

- solução 1:10 de fezes $0,5 \mathrm{ml}$

- água purificada ou destilada $2,0 \mathrm{ml}$

Misturar bem.

\subsection{Exame macroscópico das fezes}

Esta etapa inclui a pesagem da amostra de fezes utilizando balança com precisão de $0,01 \mathrm{~g}$, observação da forma, da coloração, do odor, da consistência e presença ou não de alimentos não digeridos nas fezes.

\subsection{Exame microscópico das fezes}

\subsubsection{Exame direto}

- duas gotas da solução de fezes 1:10 são observadas em microscopia de luz, entre lâmina e lamínula, para pesquisa de gotículas de gordura, fibras musculares e amido.

\subsubsection{Pesquisa de fibras musculares e amido}

- adicionando uma gota de solução de iodo a 2\% (Lugol) em duas gotas da solução fecal $1: 10$

Amido: o resultado positivo se caracteriza pela observação de estruturas coradas em azul ou negro, com morfologia compatível.

Fibras musculares: o resultado positivo se caracteriza pela observação de estriações em estruturas coradas em amarelo.

\subsubsection{Pesquisa de gordura}

- adicionando três gotas do corante Sudam III a 3\% em duas gotas da solução fecal 1:10

Gotículas de gordura neutra: o resultado positivo se caracteriza pela coloração laranja ou vermelha das gotículas. 


\subsection{Pesquisa de tripsina fecal em tubo de gelatina}

O princípio do método se baseia na capacidade da tripsina digerir a gelatina, uma vez que a presença desta enzima incubada com a gelatina não permite que essa solidifique.

Procedimentos:

1. preparar solução 1:10 de fezes, partindo de $0,25 \mathrm{~g}$ de fezes acrescentar 2,25 $\mathrm{ml}$ de água purificada ou destilada. Misturar bem.

2. Preparar solução 1:50 de fezes, partindo de $0,5 \mathrm{ml}$ da solução $1: 10$ e acrescentar 2,0 $\mathrm{ml}$ de água purificada ou destilada.

3. Montar tubos com $1 \mathrm{ml}$ de gelatina a $7,5 \%$ e adicionar $0,5 \mathrm{ml}$ de bicarbonato de sódio a $5 \%$.

4. Pipetar $0,5 \mathrm{ml}$ da solução 1:10 nos tubos com gelatina e bicarbonato de sódio. Homogeneizar. Repetir o procedimento para a solução de fezes 1:50.

5. Pipetar $0,5 \mathrm{ml}$ de água purificada ou destilada e adicionar no tubo com gelatina e bicarbonato de sódio, que será o tubo branco da reação. Homogeneizar.

6. Incubar todos os tubos à $37^{\circ} \mathrm{C}$ durante uma hora em banho-maria.

7. Resfriar os tubos durante 20 minutos à temperatura de refrigeração e realizar a leitura. Ou resfriar a temperatura de freezer até que o tubo branco esteja solidificado.

Resultado: a não solidificação indica a presença da enzima tripsina. O tubo branco deve solidificar a temperatura de refrigeração ou de freezer. A amostra controle deve permanecer líquida. 


\section{ANEXO B}

\section{EXAME COPROPARASITOLÓGICO}

\section{Método centrífugo-flutuação em solução saturada de açúcar}

Objetivo: pesquisa de cistos de Giardia sp. e ovos leves.

1. Preparo da solução A partindo de $1 \mathrm{Kg}$ de açúcar e $780 \mathrm{ml}$ de água. Mexer sob aquecimento até completa diluição do açúcar e início de ebulição.

2. Preparo da solução B partindo de três partes da solução A e uma parte de água. Conservar em geladeira.

3. Dissolver aproximadamente $1 \mathrm{~g}$ de fezes em $9 \mathrm{ml}$ da solução B.

4. Filtrar utilizando malha de gaze e completar até $10 \mathrm{ml}$ com solução B.

5. Centrifugar por 10 minutos à $1500 \mathrm{rpm}$.

6. Utilizando alça de platina, retirar duas gotas do sobrenadante e observar em microscopia de luz, entre lâmina e lamínula.

\section{Método de centrífugo-sedimentação em água-éter}

Objetivo: pesquisa de ovos pesados e cistos de Giardia sp.

1. Dissolver aproximadamente $1 \mathrm{~g}$ de fezes em $9 \mathrm{ml}$ de água purificada ou destilada.

2. Filtrar $1 \mathrm{ml}$ utilizando malha de gaze dobrada e completar para $8 \mathrm{ml}$.

3. Adicionar $4 \mathrm{ml}$ de éter etílico PA. Tampar com rolha e homogeneizar, cuidadosamente, por inversão do tubo.

4. Centrifugar por 1 minuto à $1000 \mathrm{rpm}$.

5. Desprezar o sobrenadante.

6. Homogeneizar o sedimento e retirar uma gota. Adicionar uma gota de Lugol e observar em microscopia de luz, entre lâmina e lamínula. Examinar pelo menos três lâminas do sedimento. 


\section{ANEXO C}

\section{EXAME DE URINA}

\section{Exame físico}

O exame físico foi realizado sempre antes da centrifugação da amostra, enquanto as demais etapas após a centrifugação. Assim, a avaliação física incluiu volume da amostra, coloração, aspecto, odor e densidade urinária (utilizando refratômetro manual).

Após este procedimento inicial, as amostras de urina foram centrifugadas por 5 minutos a $\pm 1000 \mathrm{rpm}$ e o sobrenadante foi em parte usado no exame químico e parte retirado e estocado à $-4{ }^{\circ} \mathrm{C}$, em frascos apropriados, restando entre $0,5 \mathrm{ml} \mathrm{e} 1 \mathrm{ml}$ de sedimento.

\section{Exame químico}

Uma parte do sobrenadante foi usada no exame químico, que consistiu no uso de tiras reagentes Combur 10 Test ${ }^{\circledR}$. Desta forma, a urina homogeneizada foi colocada, com auxílio de pipetas Pasteur descartáveis, nas áreas reativas das tiras, o excesso foi retirado no papel absorvente e, após um minuto de espera, procedeu-se a leitura, em seqüência, comparando a coloração desenvolvida na tira com a escala de cores do tubo.

\section{Exame do sedimento urinário}

O sedimento urinário $(0,5 \mathrm{a} 1,0 \mathrm{ml})$ foi homogeneizado e uma gota foi colocada entre lâmina e lamínula e observada ao microscópio, com aumentos de 100x e 400x. 


\section{ANEXO D}

\section{TESTE DE ABSORÇÃO DE D-XILOSE}

\section{Princípio do método:}

A determinação da concentração de D-xilose excretada se baseia na reação do corante floroglucinol com a pentose, que foi absorvida no lúmen intestinal, não foi metabolizada e foi excretada na urina (D-xilosúria) (EBERTS, et al., 1979). A reação é colorimétrica e a linearidade foi estabelecida para valores entre 0,5 e $3 \mathrm{mmol}$ de xilose/L.

\section{Reagentes:}

Corante Floroglucinol (1,3,5-trihidroxibenzeno), PA

Ácido acético glacial, PA

Ácido hidroclorídrico fumegante, PA

D-xilose, PA

\section{Preparo do corante:}

$0,5 \mathrm{~g}$ floroglucinol

$100 \mathrm{ml}$ ácido acético glacial, PA

$10 \mathrm{ml}$ ácido hidroclorídrico concentrado e fumegante, PA

\section{Preparo da solução aquosa de D-xilose:}

$5 \mathrm{~g}$ d-xilose

$5 \mathrm{ml}$ de água purificada

\section{Procedimento com o animal:}

1- jejum de 12 horas, durante a noite

2- colheita da primeira urina (branco da urina)

3- administrar solução aquosa de D-xilose na dose de $500 \mathrm{mg} / \mathrm{Kg}$ de peso. Solução aquosa de $5 \mathrm{~g} / 5 \mathrm{ml}$ de água.

4- colocar o animal na gaiola montada com tela e funil para colheita de urina de 5 horas. O animal deve permanecer em jejum alimentar, porém pode beber suco de fruta a vontade. 
5- encaminhar a amostra de urina para o laboratório.

\section{Procedimento no laboratório:}

1- medir o volume total de urina.

2- centrifugar $10 \mathrm{ml}$ durante 5 minutos a 1000rpm. Desprezar o restante.

3- retirar alíquota de $1,5 \mathrm{ml}$ de urina e acondicionar em tubo de centrífuga com capacidade de 1,5 ml. Identificar corretamente. Desprezar o restante.

4- pipetar $5 \mathrm{ml}$ do corante previamente preparado em cada tubo, incluindo no tubo branco da reação.

5- colocar em tubos de ensaio grandes a seguinte seqüência:

a) $50 \mu 1$ de água purificada (branco), em duplicata

b) $50 \mu 1$ de solução padrão de d-xilose a $0,5 \mathrm{mmol}$, em duplicata

c) $50 \mu 1$ de solução padrão de d-xilose a 2,4 mmol, em duplicata

d) $50 \mu 1$ da urina 1 , em duplicata

e) $50 \mu 1$ da urina de 5 horas com d-xilose, em duplicata

6- aquecer os tubos testes e controles à $100^{\circ} \mathrm{C}$ por 4 minutos.

7- esfriar os tubos com rápida imersão em água a temperatura ambiente.

8- homogeneizar as amostras.

9- realizar a leitura da absorbância, em espectrofotômetro, em comprimento de $554 \mathrm{~nm}$. Ajustar o aparelho no zero utilizando os tubos brancos, antes da leitura dos tubos padrões e testes

10- calcular a concentração de d-xilosúria a partir da absorbância alcançada nos tubos padrões e testes (regra de três). 